Universidade de São Paulo.

Faculdade de Filosofia, Letras e Ciências Humanas.

Departamento de Sociologia

Programa de Pós-Graduação em Sociologia

\title{
A FAMÍLIA E AS MEDIDAS SOCIOEDUCATIVAS
}

\section{A INSERÇÃO DA FAMÍLIA NA SOCIOEDUCAÇÃO DOS ADOLESCENTES AUTORES DE ATO INFRACIONAL.}

Liana de Paula

Orientação: Profa. Dra. Maria Helena Oliva Augusto

São Paulo, 2004. 
Universidade de São Paulo.

Faculdade de Filosofia, Letras e Ciências Humanas.

Departamento de Sociologia

Programa de Pós-Graduação em Sociologia

\section{A FAMÍLIA E AS MEDIDAS SOCIOEDUCATIVAS} A INSERÇÃO DA FAMÍLIA NA SOCIOEDUCAÇÃO DOS ADOLESCENTES AUTORES DE ATO INFRACIONAL.

Dissertação apresentada ao Programa de Pós-Graduação em Sociologia, do Departamento de Sociologia da Faculdade de Filosofia, Letras e Ciências Humanas da Universidade de São Paulo, para obtenção do título de Mestre em Sociologia.

Orientadora: Profa. Dra. Maria Helena Oliva Augusto

São Paulo, 2004. 
Aos meus avós, meus pais, ao meu irmão Lucas e ao meu companheiro Renato. 


\section{AGRADECIMENTOS}

Desde o início de minha formação acadêmica, tive a oportunidade de conhecer e conviver com pessoas que, a seu modo, inspiraram, incentivaram, colaboraram ou apoiaram a realização desta dissertação. Assim, gostaria de agradecer a todas por terem tornado possível a conclusão de mais uma etapa de minha trajetória.

Agradeço aos professores de pós-graduação e graduação, com os quais pude aprender o sentido da vocação que esta carreira exige, as alegrias, a dedicação, a seriedade, a responsabilidade e, enfim, a realização profissional e também pessoal que ela oferece.

Agradeço especialmente à Maria Helena Oliva Augusto, pela instigação intelectual, pela generosidade e pela dedicação em orientar meu trabalho. Seu acolhimento foi fundamental para estimular-me a enfrentar as dificuldades e os estranhamentos decorrentes da mudança de cidade e de instituição. Sua contribuição acadêmica foi essencial no direcionamento deste trabalho e se tornou fonte de inspiração para investir permanentemente no projeto de amadurecimento intelectual.

Agradeço também a Irene Cardoso e Sérgio Adorno, cujas contribuições em meu exame de qualificação foram extremamente relevantes no momento em que foi necessária uma reflexão sobre os objetivos, os rumos e as possibilidades deste trabalho.

Agradeço a Lourdes Bandeira, Carlos Benedito Martins e Brasilmar Ferreira Nunes, que acompanharam e estimularam o início de minha trajetória acadêmica.

Gostaria também de agradecer àqueles que estiveram diretamente relacionados à produção desta dissertação, como colaboradores. Nesse sentido, agradeço às informações preciosas oferecidas por Rosane Vianna e pelas 
fundadoras da Associação de Mães e Amigos do Adolescente em Risco - AMAR, D. Conceição, Cida, Railda e Miriam, mulheres que transformaram a experiência de internação dos filhos em trajetórias politizadas de engajamento e luta na defesa dos direitos da criança e do adolescente. A elas, gostaria de expressar não somente meu agradecimento pelo acolhimento nos meses que freqüentei a AMAR, mas também minha profunda admiração por sua dedicação e persistência frente às adversidades de seu trabalho.

Há também outros colaboradores, cujo apoio emocional foi essencial para a realização desta. Agradeço ao Renato, meu companheiro, aos meus pais, ao meu irmão Lucas e aos meus avós maternos e paternos pelo incentivo, pela paciência, pelo carinho e pelo afeto que ajudaram a superar os momentos de angústia e dúvida em relação ao meu trabalho.

Agradeço também aos velhos amigos de Brasília e aos novos amigos de São Paulo - Tatiana Guedes, Nara Kolrsdorf, Ricardo Mendes, Celina Bruniera, Rosane Batista, Alessandra Teixeira, Sérgio Mazina, Melissa Pimenta, Sylvia Cioff, Mauricio Pelegrini, Marco Aurélio Moura e Beatriz Borim - pelo incentivo constante e pela compreensão nos momentos de "loucura" e de incomunicabilidade que envolvem a conclusão de uma dissertação.

Por fim, restam os agradecimentos ao aparato institucional e financeiro, sem os quais seria impossível concretizar este trabalho. Nesse sentido, agradeço à Coordenadoria de Aperfeiçoamento de Pessoal do Ensino Superior - Capes, pela bolsa de estudos concedida por dois anos do mestrado, e à Secretaria de PósGraduação em Sociologia da Universidade de São Paulo, particularmente à Ângela, Samara e Irani pela ajuda nos momentos de apuros burocráticos. Enfim, agradeço também a Anna Maria Martins e Guaracy Mingardi, pelas oportunidades de trabalho que me ofereceram após o término da bolsa. 


\section{RESUMO}

Esta dissertação visou discutir a relação entre o Estado e as famílias de adolescentes autores de ato infracional a partir das propostas do Estatuto da Criança e do Adolescente. Por intermédio de pesquisa documental e bibliográfica, procurouse traçar uma abordagem histórica e teórica que permitisse salientar a possibilidade de transformação da interferência do Estado na vida familiar, no sentido de uma redução das tendências repressivas e do estabelecimento de outros tipos de controle, que visam regulamentar os processos de socialização e individualização de crianças e adolescentes pobres.

Palavras-chave: Estatuto da Criança e do Adolescente, família, Estado, socialização e individualização.

\section{$\underline{\text { ABSTRACT }}$}

This dissertation aimed to discuss the relationship between the State and the families of the juvenile delinquents by analysing the proposals of the Estatuto da Criança e do Adolescente. Using the data of the documentary and bibliographical research, historical and theoretical approachs were adopted in order to emphasize the possible changes regarding the interference of the State in the familial life. These changes indicate a reduction of the repressive trends and the establishment of other kinds of regulation towards the socialization and individualization processes of the poor children and adolescents.

Keywords: Estatuto da Criança e do Adolescente,, family, State, socialization and individualization. 


\section{SUMÁRIO}

Resumo/Abstract 06

Introdução 08

\section{Capítulo I}

Construindo o problema de investigação sociológica 12

São Paulo: da sensação de caos à defesa do Estatuto da Criança e do Adolescente 24

Repensando a família no contexto paulista 43

\section{Capítulo II}

A trajetória da família na internação do adolescente 53

Instituições "indisciplinadas": as famílias coloniais e a Roda dos Expostos ............ 56

O destino dos "sem-família": da filantropia religiosa ao problema de Estado .......... 63

O Instituto Disciplinar e o Código de Menores de 1927 ........................................ 71

Tentativas de centralização dos serviços de assistência: o Serviço de Assistência a Menores e o Recolhimento Provisório de Menores. 76

A internação coroada: os militares e a Fundação Estadual do Bem-Estar do Menor. 79

\section{Capítulo III}

$(\mathrm{Re})$ Socialização da família: os desafios da atualidade 88

Família moderna e socialização: o problema da padronização 93

Famílias contemporâneas e socialização: o problema da fragmentação 100

A importância da norma na reflexão sobre família, indivíduo e Estado: a gestão das incertezas

Conclusão

Bibliografia de referência 126 


\section{INTRODUCÃO}

A preocupação com a infância e a adolescência, com seu desenvolvimento e seu destino, não é algo realmente novo no Brasil. Desde o século $\mathrm{XIX}$, essas fases iniciais da vida têm sido alvo privilegiado das atenções daqueles que pretendem ocupar-se do "futuro da nação". Nesse sentido, preocupar-se com a infância e a adolescência significa concebê-las como a "semente do futuro", isto é, como a base a partir da qual se formará o indivíduo de amanhã.

Não obstante as diferentes questões que despertam o interesse pela infância e adolescência ou as diversas propostas que se fazem em relação a elas, o que parece ser mais essencial é sua valorização como o momento crucial que determinará a formação do indivíduo. E é justamente a partir dessa valorização que a família, a escola e o Estado ganham relevância como instituições autorizadas ou desautorizadas para realizar essa formação.

Assim, o interesse pela infância e adolescência envolve uma série de instituições que atuam sobre elas de modo a formar o indivíduo. Se essas instituições são capazes de formar o indivíduo socialmente desejável, garantindo tanto a internalização de normas de conduta socialmente aceitáveis quanto a integração em redes de sociabilidade, é uma das questões mais primordiais colocadas nos discursos sobre a infância e a adolescência.

Dentre esses discursos, há aqueles que se direcionam, mais especificamente, aos adolescentes autores de ato infracional, isto é, aos indivíduos entre 12 anos completos e 18 anos incompletos a quem se atribui conduta considerada como crime ou contravenção penal. ${ }^{1}$ Os discursos referentes a esses

\footnotetext{
${ }^{1} \mathrm{O}$ termo "adolescente" adotado nesta dissertação refere-se à faixa etária definida pelo Estatuto da Criança e do Adolescente. No entanto, uma conceituação sociológica teria de considerar variações históricas e sociais nas delimitações das diferentes etapas da vida; particularmente, as que dividem a infância, a adolescência e a juventude. Uma discussão em termos sociológicos pode ser encontrada na dissertação de Régia de Oliveira (2001:24-33) sobre jovens trabalhadores em São Paulo.
} 
adolescentes dividem-se, por sua vez, entre dois pólos antagônicos, a saber, o do aprisionamento e da segurança e o da reforma das condutas e da terapêutica.

No primeiro pólo, estariam os defensores da redução da idade penal. Para esses, o crescimento da criminalidade urbana estaria relacionado à sensação de impunidade, que levaria os jovens com menos de 18 anos a serem mais violentos por saberem que não irão para a prisão. Os reducionistas acreditam, então, que a solução dos problemas de segurança passaria pela redução da idade penal para 16 ou mesmo 14 anos, diminuindo a sensação de impunidade e aumentando o medo da pena entre os jovens.

Porém, há diversos questionamentos possíveis em relação a esse pólo e sua solução simplificada para fenômenos tão complexos quanto a criminalidade e o envolvimento de jovens com atos ilícitos e/ou violentos. Sem esgotar tais questionamentos, gostaria de levantar apenas um que, a meu ver, é central, ao indicar a adoção de concepções distintas da adolescência entre os dois pólos.

A redução da idade penal visa igualar a pena atribuída aos adultos e adolescentes, negando-Ihes qualquer especificidade enquanto fase de formação do ser humano. No entanto, a inimputabilidade desses últimos não significa, necessariamente, impunidade. Ou seja, o fato de que os jovens com menos de 18 anos sejam inimputáveis não implica que, cometendo um ato ilícito, eles não receberão nenhum tipo de punição. Pelo contrário, e como se abordará em diversos momentos desta dissertação, a legislação em vigor determina-lhes uma punição específica, inserida em uma concepção da adolescência como período de desenvolvimento do ser humano, no qual o indivíduo é mais vulnerável e frágil que o adulto.

Nesse sentido, as medidas socioeducativas previstas pelo Estatuto da Criança e do Adolescente (lei $\mathrm{n}^{\circ}$ 8.069/90) procuram assegurar que haja uma dimensão pedagógica ou terapêutica quando se trata de punir esses indivíduos em desenvolvimento. Assim, a defesa do Estatuto é uma das principais características do segundo pólo de discursos sobre os adolescentes autores de ato infracional, que 
buscam garantir a implantação de políticas de atendimento que tenham como base a concepção do adolescente como pessoa em desenvolvimento.

Por um lado, essa concepção indica uma mudança histórica em relação aos modos de punição e tratamento a partir da entrada da família na terapêutica socioeducativa. Assim, as famílias dos autores de ato infracional tornamse responsáveis pelo sucesso de sua re-educação, ao mesmo tempo que são inseridas como objeto de intervenção da ação re-educativa do Estado. Porém, essa afirmação da centralidade da família parece apontar, por outro lado, uma contradição, pois, na contemporaneidade, a família tende a ser cada vez mais um agrupamento incerto e contingente, o que implicaria poucas possibilidades de assegurar a formação das novas gerações.

E é sobre essa aparente contradição que se pretende refletir nesta dissertação. Assim, o primeiro capítulo busca desenvolvê-la melhor enquanto um problema de pesquisa a ser construído a partir das questões que se colocam no contexto de aplicação das medidas socioeducativas da cidade de São Paulo. $O$ segundo capítulo, por sua vez, apresenta uma abordagem histórica que visa demonstrar os deslocamentos na relação entre famílias de autores de ato infracional e Estado, ao longo do século XX, desde o primeiro Código de Menores. Enfim, o terceiro capítulo busca uma problematização teórica sobre esses deslocamentos, priorizando a contradição aparente entre a desinstitucionalização da família e sua centralidade na formação dos indivíduos.

No que se refere à metodologia adotada, esta envolveu as etapas de localização e realização de inventário dos documentos e da bibliografia pertinentes ao tema e de avaliação do material encontrado de acordo com critérios de representatividade e relevância em relação à problemática desta pesquisa. Nesse sentido, privilegiou-se a composição de diferentes fontes documentais e bibliográficas, selecionadas conforme os objetivos históricos e teóricos que a pesquisa demandava.

Dentre as fontes consultadas, estão os sítios do Instituto Brasileiro de Geografia e Estatística - IBGE, da Fundação Estadual do Bem-Estar do Menor de 
São Paulo - Febem/SP, da Imprensa Oficial do Estado de São Paulo, onde se encontram todos os decretos e leis referentes à Febem-SP, desde 1976; o banco de dados da produção acadêmica da Universidade de São Paulo, com ênfase na Faculdade de Filosofia, Letras e Ciências Humanas; e as referências bibliográficas indicadas pela orientadora e pela banca do exame de qualificação. Foram também consultados os arquivos de entidades de defesa dos direitos humanos, tais como a Comissão Teotônio Vilela, a Anistia Internacional e o UNICEF.

O material selecionado foi avaliado a partir do contexto histórico-social de sua produção, dos posicionamentos dos autores, da credibilidade das informações fornecidas e da estrutura do texto, isto é, seus conceitos-chave e sua lógica interna. ${ }^{2}$ Assim, foram realizadas fichas de leitura que permitiram comparar as diferentes abordagens em relação aos elementos considerados centrais a esta discussão, a saber, família, adolescência, Estado, instituições públicas de punição e assistência, individualização, socialização e ressocialização.

Embora a análise tenha utilizado, exclusivamente, fontes documentais e bibliográficas, testemunhos de indivíduos relacionados ao tema foram usados para nortear a seleção do material relevante e as formas de aproximação da temática e construção do problema. Nesse sentido, foram entrevistadas duas das fundadoras da Associação de Mães e Amigos do Adolescente em Risco - AMAR - e dois exfuncionários da Febem-SP, uma do corpo técnico e outro da diretoria pedagógica. No entanto, não houve um controle rigoroso na coleta desses testemunhos, de modo que não constituíram material de análise.

Por fim, acredita-se que a discussão aqui apresentada possa ser enriquecida a partir da realização de novas pesquisas, que enfatizem a coleta e análise de testemunhos.

\footnotetext{
${ }^{2}$ Para a discussão desta metodologia, ver Cellard, 1997.
} 


\title{
Capítulo I
}

\section{CONSTRUINDO O PROBLEMA DE INVESTIGAÇÃO SOCIOLÓGICA}

\begin{abstract}
O momento mais difícil foi quando meu filho, no começo da rebelião, tentou fuga e quebrou os dois calcanhares. Ele não tem calcanhar, tem platina, então tem uma deficiência hoje, infelizmente. E a minha maior mágoa da Febem (...) foi quando ele ficou jogado por três dias num PS do Hospital do Tatuapé e ninguém me comunicou; na minha casa tinha telefone e eu era uma mãe presente. Conceição Paganele, presidente da Associação de Mães e Amigos de Crianças e Adolescentes em Risco - AMAR. ${ }^{3}$
\end{abstract}

No cotidiano das grandes cidades brasileiras, o envolvimento de jovens em atos ilícitos é um fenômeno que tende a preocupar seus habitantes e a gerar uma demanda por alternativas e soluções que visem sua prevenção, punição e correção. Para atender a essas demandas, diferentes setores da sociedade e representantes do Estado têm formulado diversas propostas, que vão desde a redução da idade penal ou o aumento do tempo de privação de liberdade às propostas que salientam a adoção de medidas de cerceamento parcial da liberdade e acompanhamento terapêutico-assistencial. ${ }^{4}$

De modo geral, essas propostas parecem oscilar entre duas perspectivas que buscam regulamentar o tratamento a ser dado aos jovens que cometeram atos legalmente desviantes. A primeira defenderia o acirramento da severidade das punições e consideraria a perda da liberdade individual como modelo geral de castigo. A segunda envolveria o investimento no aspecto recuperador e

\footnotetext{
${ }^{3}$ Trecho de entrevista concedida à revista Caros Amigos, em março de 2002.

${ }^{4}$ Sobre as propostas de redução da maioridade penal e de aumento do tempo de privação de liberdade, a série de reportagens realizadas após o assassinato de um casal de jovens na Grande São Paulo é ilustrativa. Nesse sentido, ver "Crime reabre debate sobre maioridade penal" (FSP, 15/11/2003), "Alckmin leva à Câmara proposta de mudanças no Estatuto" (Agência Estado, 19/11/2003), "Alckmin propõe pena de até 10 anos para adolescente" (Folha on-line, 19/11/2003), "Projeto endurece regime para 2/3 da Febem" (FSP, 23/11/2003).
} 
corretivo das punições, tendendo a privilegiar como modelo ressocializador a liberdade vigiada.

$\mathrm{Na}$ primeira perspectiva, a questão fundamental seria a relação atopunição, ou seja, o estabelecimento de reações institucionais progressivamente mais severas de acordo com a gravidade dos atos cometidos. Essa severidade progressiva levaria ao aumento da duração do encarceramento e do seu grau de intensidade, submetendo os jovens a procedimentos carcerários institucionais cada vez mais cerceadores, tais como a redução ou a suspensão de atividades fora das celas.

$\mathrm{Na}$ segunda, o ato ilícito em si ocuparia uma posição periférica se comparado à noção de conduta. O ato seria compreendido, então, como o resultado de trajetórias juvenis caracterizadas por descompassos na formação social das condutas individuais, isto é, sua explicação dar-se-ia pela avaliação do impacto causado por falhas no processo de socialização. Assim, a punição teria como objetivos corrigir os desvios de conduta gerados por essas falhas e, ao mesmo tempo, normalizar o processo de socialização para evitar a ocorrência de novas falhas.

Embora distintas, ambas as perspectivas parecem co-existir não somente nas diferentes propostas formuladas por setores da sociedade e representantes de Estado, mas também na história nacional das legislações e dos modelos de punição destinados aos jovens. Nesse sentido, o Estatuto da Criança e do Adolescente (lei 8069/90), que é uma das legislações em vigor, parece inclinar-se à segunda delas. Isso porque ele prevê que a punição destinada aos indivíduos entre 12 anos completos e 18 anos incompletos não seja somente uma pena, mas uma medida socioeducativa, que busca afirmar a importância da dimensão pedagógica e da correção das condutas dos adolescentes a partir de uma concepção na qual eles sejam considerados indivíduos em formação.

Tendo como base essa concepção, uma das diretrizes de aplicação das medidas socioeducativas seria a "desinstitucionalização", entendida como a 
restrição do encarceramento em unidades de internação a situações excepcionais. ${ }^{5}$ Desse modo, o Estatuto parece indicar uma mudança significativa em relação às legislações anteriores, que adotavam o encarceramento como modelo geral de punição e tratamento. Tal mudança tenderia a deslocar a centralidade desse procedimento e a difundir novas técnicas punitivo-pedagógicas que fariam da liberdade vigiada o modelo ideal de ressocialização.

Nesse modelo, o recurso às famílias de origem, aos pais e mães, parece destacar-se como forma de assegurar o sucesso e a eficácia pedagógicos. A liberdade vigiada mantém o adolescente em seu ambiente doméstico e estabelece a supervisão de diferentes aspectos de sua vida por orientadores sociais, com o objetivo de corrigir eventuais falhas no seu processo de socialização. A correção, porém, não se limita ao indivíduo, mas envolve também as instituições sociais que seriam responsáveis por esse processo, a saber, a escola, o trabalho e a família. Nesse sentido, a supervisão busca assegurar a escolarização e a profissionalização, entendidas como a inserção, a freqüência e a conclusão do ensino médio ou fundamental e de cursos profissionalizantes. Ademais, propõe a reorganização da vida familiar por meio de intervenções terapêuticas, médicas ou econômicoassistenciais.

Assim, o modelo da liberdade vigiada tende a indicar uma valorização da família no processo de ressocialização, uma vez que sua supervisão é parte integrante desse processo. Em contrapartida, parece implicar também sua transformação em objeto de investimento recuperador de condutas, ou seja, a regulamentação e o controle das condutas individuais "desviantes" passam a ser operacionalizados por técnicas punitivo-pedagógicas que incidem sobre a vida familiar e visam modificá-la em nome do estabelecimento de um processo socializador sem falhas e, portanto, sem "desvios" individuais.

\footnotetext{
${ }^{5}$ Publicado anteriormente à promulgação do Estatuto da Criança e do Adolescente, o texto de Maria Ignês Bierrenbach (1987:65), ex-presidente da Fundação Estadual do Bem-Estar do Menor de São Paulo - Febem-SP, define o significado operacional da "desinstitucionalização" como a nãointernação e a desinternação.
} 
Esta dissertação procura abordar, então, a dupla mudança no sentido da valorização das famílias de adolescentes que se envolvem com atos ilícitos e de sua transformação em ponto de intervenção ressocializadora. Para tanto, o ponto de partida refere-se à construção do problema sociológico a ser investigado, ou seja, ao percurso pelo qual a experiência no campo das medidas socioeducativas instigou a tentativa de uma reflexão sociológica sobre questão familiar. Assim, este capítulo visa apresentar como tal questão foi surgindo a partir de contatos, ora ao acaso, ora deliberados, com diversos informantes e documentos que contribuíram para formular uma problematização sobre o lugar da família nas medidas socioeducativas.

É bem possível que outro pesquisador, estando em contato com os mesmos informantes ou lendo os mesmos documentos, percebesse outras questões como relevantes. Assim, a problematização que aqui se apresenta é, como qualquer outra, uma escolha deliberada.

A justificativa de tal escolha remete ao momento em que surgiu a idéia de estudar a relação entre famílias e medidas socioeducativas, em 1999. Nesse sentido, o ano de 1999 foi bastante significativo devido, primeiramente, à ocorrência de uma das maiores crises da Fundação Estadual do Bem-Estar do Menor de São Paulo - Febem-SP, instituição responsável pela execução das medidas nesse estado. Em segundo lugar, foi naquele mesmo ano que a pesquisadora iniciava sua trajetória nesse campo, por intermédio de uma pesquisa cuja coleta de dados foi realizada no Centro de Atendimento Juvenil Especializado - CAJE, instituição responsável pela medida de internação no Distrito Federal.

A profunda crise atravessada pela Febem-SP, ao longo de 1999, foi marcada por uma série de fugas maciças e rebeliões de dimensões sem precedentes no histórico dessa instituição. Como uma crônica de uma crise anunciada, as entidades de defesa dos direitos humanos já haviam alertado e denunciado que a situação de superlotação, tortura e maus-tratos tinha atingido níveis insuportáveis. É importante ressaltar que essa situação de violência 
institucional não era atípica, mas era e é ainda uma constante, atingindo, de quando em quando, um alto grau de tensão que termina por eclodir em conflitos violentos. ${ }^{6}$

Contudo, nenhum dos conflitos se comparou (ainda) àqueles ocorridos entre os meses de setembro e outubro de 1999 no complexo de unidades de internação da Rodovia dos Imigrantes. Em setembro, ali se registrou um número altíssimo de fugas, somando 644 adolescentes evadidos. Mas, foi no final de outubro que a situação tomou proporções realmente trágicas, quando o anúncio de greve dos monitores foi o estopim para uma rebelião que destruiu o complexo, deixando atrás de si quatro adolescentes mortos e vários feridos, entre internos e monitores.

Durante a rebelião, que durou dezoito horas, um grupo de internos instalou-se no telhado, com camisetas enroladas no rosto para não serem identificados pelas câmeras fotográficas e de televisão, e deu início a um espetáculo de crueldades para os que estavam do lado de fora dos muros. De seu palco improvisado, mostraram seus reféns, que, sem camisetas ou capuzes no rosto, puderam ser reconhecidos pelos que assistiam lá embaixo e de fora.

\footnotetext{
${ }^{6}$ A violência institucional permanente parece operar de maneira cíclica na Febem-SP. Por um lado, essa violência, produzida pela superlotação, pelos maus-tratos, pela tortura e pela imposição de uma conduta subserviente (como andar de cabeça baixa, com as mãos para trás e tratar os funcionários como "senhor") é institucionalizada, ou seja, faz parte do atendimento fornecido pela Febem-SP ao adolescente em conflito com lei. De fato, desde 1979 (três anos após sua criação), a Febem-SP tem sido denunciada, juntamente com a polícia, como uma das instituições de Estado responsáveis por maus-tratos e violência a crianças e adolescentes. (Cf. Alvin \& Valadares, 1988). Por outro lado, não se pode perder de vista o possível caráter institucionalizado das rebeliões. Há, sem dúvida, a "visibilidade perversa" apontada por Mione Sales (2003), que percebe as rebeliões como um dispositivo de expressividade dos adolescentes diante da violência a eles dirigida. Contudo, as rebeliões parecem operar, também, de modo a reequilibrar a violência institucional dos funcionários, pois extravasam a reação contida dos adolescentes e podem ser usadas, pelos funcionários, como justificativa para perpetuar sua ação violenta (principalmente, quando um monitor é ferido ou morto). Então, é pertinente perguntar se a rebelião não seria, ela mesma, uma manifestação da violência institucional, ou seja, se essa reação dos adolescentes não faria parte da relação monitores/adolescentes. Assim, a perversidade parece estar menos na forma violenta como os adolescentes procuram afirmar sua visibilidade enquanto sujeitos e mais na forma como a instituição Febem-SP se apropria de toda e qualquer tentativa de afirmação de subjetividade - 0 efeito perverso da "rebelião", aquele que não foi previsto por seus atores, é a apropriação de sua possibilidade reivindicatória pela própria instituição à qual a reivindicação se dirigiu. Nesse sentido, pensar as maneiras pelas quais a Febem-SP se apropria das reivindicações contra ela pode ser uma abordagem relevante para entender porque as rebeliões de 1999 não conseguiram produzir mudanças mais profundas.
} 
Dentre os desafetos tomados como reféns, havia tanto monitores quanto outros adolescentes. Possivelmente, os monitores haviam sido escolhidos para reféns a partir de seu envolvimento com tortura e maus-tratos. Mas, a presença de internos dentre os reféns não é algo simples de explicar. Nesse sentido, é importante salientar alguns aspectos específicos de instituições como as unidades de internação da Febem-SP.

Nelas, a existência de alas de "seguro" aponta para uma "cultura" em que determinados atos ilícitos são desvalorizados pelos próprios adolescentes. A violência sexual, por exemplo, constitui um tabu. Os que foram internados por terem cometido atos infracionais sexuais, como estupro ou atentado violento ao pudor, não são aceitos pelos demais. ${ }^{7}$ Para evitar que o convívio entre eles ocasione novos atos de violência sexual ou morte, os funcionários separam os autores desses atos em uma ala chamada de "seguro". ${ }^{8}$

Rejeição semelhante é vivida pelos “alcagüetes", os que denunciam seus iguais para os funcionários. Como a punição estabelecida pelos próprios adolescentes aos "alcagüetes" é a morte, esses últimos também são isolados no "seguro". Ou seja, o "seguro" é um depósito de desafetos dos demais adolescentes internados e, por isso, torna-se um alvo preferencial nos momentos de rebelião.

Do alto do telhado de um dos prédios do complexo Imigrantes, internados e internados, adolescentes e adolescentes, uns com o rosto coberto, outros com o rosto à mostra, uns, rebelados, empunhando paus e estiletes, outros, dominados, servindo de escudo e alvo. Do lado de fora, amontoados nas cercas, pais e mães aflitos procuravam notícias de seus filhos ali internados. Alguns

\footnotetext{
${ }^{7}$ Não obstante a rejeição aos que foram internados por cometerem atos infracionais sexuais, adolescentes internados por outros atos infracionais podem se inserir em relações sexuais não consentidas a partir de seu ingresso na unidade de internação. Devido à forte reprovação dos "alcagüetes", o abuso sexual causado por outros adolescentes pode ser silenciado pelas vítimas, por medo de represálias. Assim, a questão da sexualidade produz um choque entre valores que se tornam antagônicos na situação específica de internação (como a condenação ao que comete violência sexual e ao que quebra o silêncio imposto pelo espírito de grupo entre internados).

${ }^{8}$ Nesse sentido, a política do "seguro" coloca a questão da exclusão social na vida intramuros, pois os adolescentes "indesejáveis" ou "intoleráveis" pelos demais são simplesmente afastados do convívio. Algo semelhante ocorre com a ala "disciplinar", onde os assim considerados pelos funcionários são trancafiados em pequenas celas individuais.
} 
assistiram ao esfaqueamento de seus filhos pelos colegas encapuzados, enquanto os portões continuavam fechados para eles.

De todas as cenas da rebelião de 1999, ficou marcada a dos pais e mães amontoados nas cercas sem nada poderem fazer para proteger seus filhos, enquanto a rebelião, literalmente, colocava a baixo o complexo Imigrantes. ${ }^{9}$ Daquela cena surgiu a idéia de estudar a relação entre as famílias dos adolescentes e as instituições responsáveis pelas medidas socioeducativas. No entanto, ainda seria percorrido um longo caminho até que o problema desta dissertação pudesse se definir mais claramente.

Naquele mesmo ano, tinha início a trajetória da pesquisadora no mundo das unidades de internação. A entrada efetiva no Centro de Atendimento Juvenil Especializado - CAJE, única unidade de internação existente no Distrito Federal naquele período, deu-se em 2000. Ao longo daquele ano, o CAJE foi fonte de dados para duas pesquisas, uma delas resultou em um relatório para o Programa Institucional de Bolsas de Iniciação Científica - PIBIC, e a outra, na monografia de conclusão de curso. ${ }^{10}$

\footnotetext{
${ }^{9}$ Segundo a Anistia Internacional (2000:12), a rebelião atingiu a totalidade do complexo no dia 24 de outubro. Dezoito horas mais tarde, havia quatro adolescentes mortos, 58 pessoas feridas, inclusive 29 funcionários da Febem, dezenas de adolescentes haviam escapado e o complexo de Imigrantes fora completamente destruído. Durante a rebelião, cerca de 16 monitores foram tomados como reféns e espancados. Vários internos também foram torturados pelos companheiros e quatro foram mortos, massacrados com tal brutalidade que causou choque mesmo entre aqueles que há anos trabalham no sistema. Os brasileiros ficaram horrorizados com as imagens de adolescentes com a camiseta enrolada na cabeça para esconder o rosto, completamente descontrolados, submetendo monitores e companheiros a maus-tratos e tortura ante as câmeras de televisão. As tropas de choque da Polícia Militar dispararam balas de borracha contra os pais ansiosos que aguardavam notícias do lado de fora dos portões do complexo.

${ }^{10}$ A pesquisa do PIBIC foi realizada por um professor e duas bolsistas e privilegiou a perspectiva daqueles para quem o CAJE se destina - os adolescentes ali internados. No que se refere à operacionalização da pesquisa, o trabalho de campo foi dividido em três fases. Na primeira, foram aplicados questionários aos adolescentes internados no Centro de Atendimento Juvenil Especializado - CAJE -, procurando traçar seu perfil socioeconômico. Na segunda, foram feitas trajetórias de vida de alguns desses adolescentes. Por fim, foram realizadas observações não-participantes do cotidiano do CAJE, nas quais os adolescentes de uma das alas masculinas foram acompanhados em suas atividades na escola e nas oficinas profissionalizantes. Estava prevista também a realização de uma análise de conteúdo dos jornais em circulação em Brasília. Contudo, essa análise não foi feita em virtude da complexidade do trabalho de campo e do pouco tempo disponível para a finalização da pesquisa. Sobre os resultados, ver Paula, 2000a. A pesquisa de conclusão de curso, por sua vez, procurou abordar a perspectiva dos funcionários, assinalando suas representações sobre a
} 
A inserção no cotidiano de uma unidade de internação foi fundamental para aprofundar a idéia inicial de pensar a relação entre as famílias e as instituições responsáveis pela execução de medidas socioeducativas. Nesse sentido, destacamse o disciplinamento das condutas dos adolescentes e o problema do contágio pelo crime como chaves de compreensão dos lugares ocupados pelas famílias durante a internação de seus filhos.

O disciplinamento das condutas, conjunto de práticas pelas quais os funcionários visam conformar as condutas dos adolescentes ao que é considerado adequado para a instituição, prioriza a questão mais imediata da segurança. ${ }^{11}$ Impedir que os adolescentes fujam, que agridam verbal ou fisicamente os funcionários ou que se rebelem são tensões diárias e constantes que transformam a manutenção da ordem na condição para assegurar o funcionamento desse tipo de instituição.

Assim, o disciplinamento dos adolescentes mobiliza as ações administrativas da unidade de internação, de tal modo que se tornam secundárias as atividades socioeducativas, como a escola e as oficinas profissionalizantes. Isso ocorre em dois sentidos: em primeiro lugar, essas atividades não são a questão administrativa mais imediata ou prioritária e, em segundo, elas se inserem num jogo disciplinar de premiação e punição, cujo grande prêmio é a desinternação.

Esse jogo coloca em avaliação permanente o grau de "cooperação" com a ordem institucional que os funcionários podem obter de cada adolescente. Geralmente, a indisciplina significa qualquer manifestação contrária do adolescente e é comumente punida com a privação do direito de freqüentar as atividades socioeducativas. ${ }^{12}$ Contudo, há situações em que o próprio adolescente manifesta

sexualidade dos adolescentes com quem trabalham. Foram feitas doze entrevistas, seis com funcionários responsáveis pela segurança da unidade e seis com aqueles que compõem o grupo técnico (em sua maioria, assistentes sociais, pedagogos e psicólogos). Cf. Paula, 2000b.

11 O disciplinamento das condutas é tão importante para os funcionários de uma unidade de internação que, muitas vezes, é usado para justificar a violência institucional contra os adolescentes.

${ }^{12}$ No entanto, cada manifestação não é apreendida pelos funcionários do mesmo modo, mas é avaliada e tipificada de acordo com um sistema de gradação das gravidades. As tentativas de fuga, as agressões físicas aos funcionários e as incitações à rebelião são consideradas indisciplinas graves, punidas com o completo isolamento do adolescente em uma cela do pavilhão disciplinar. 
sua vontade de não participar das atividades - o que, por um lado, priva os funcionários de utilizá-las diretamente no jogo; mas, por outro lado, permite que essas atividades retomem seu papel punitivo nos relatórios semestrais.

Os relatórios, que são enviados periodicamente ao juiz, indicam a avaliação dos funcionários acerca da possibilidade de desinternação do adolescente e a não participação nas atividades oferecidas pelo estabelecimento é vista como um elemento desfavorável. Uma vez que a desinternação depende, em boa medida, desses relatórios, eles se tornam instrumentos de obtenção da docilidade ou de punição da indisciplina, encurtando ou prolongando a permanência do adolescente no estabelecimento.

A percepção do disciplinamento das condutas como questão-chave para os funcionários aponta uma contradição que envolve a internação como uma medida socioeducativa. Uma vez que as ações dos funcionários mobilizam-se em torno da segurança como forma de assegurar o funcionamento da instituição, relegando a dimensão pedagógica das atividades socioeducativas para segundo plano, a internação termina por acentuar a perspectiva punitiva de encarceramento. Assim, ela envolve a adoção de procedimentos institucionais cotidianos que são totalizadores, tais como a interdição à saída, o controle da circulação interna, a imposição da convivência em uma coletividade de desconhecidos e a determinação de atividades e comportamentos obrigatórios aos encarcerados. Esses procedimentos acentuam a severidade do castigo a ser recebido e tendem a reduzir a dimensão corretiva da internação à introjeção do medo de ser punido.

Nesse sentido, a contribuição de Erving Goffman (1999a) é relevante ao construir uma abordagem teórica de compreensão dessa contradição. Segundo o autor, as instituições caracterizar-se-iam, de modo geral, pelo seu fechamento em relação ao mundo social, requerendo tempo e interesse de seus participantes. Porém, na sociedade ocidental, haveria instituições em que o fechamento seria mais acentuado, colocando limitações, muitas vezes físicas, à relação social com o 
mundo externo e proibições à saída. ${ }^{13}$ Por conseguinte, as diferentes esferas da vida individual passariam a ser realizadas em um único espaço e sob uma única autoridade, de modo que seu controle burocrático constituiria o fato básico das instituições totais. $^{14}$

Boa parte dessas instituições se apresentaria, oficialmente, como forma de organização burocrático-racional para atingir a finalidade de reforma dos indivíduos internados no sentido de algum padrão ideal. Contudo, o fato de que seu material de trabalho seriam seres humanos, e não objetos inanimados, geraria uma contradição entre o que a instituição realmente faz e aquilo que oficialmente deve dizer que faz. ${ }^{15}$ Essa contradição, enfim, seria o contexto básico do cotidiano dos funcionários.

Além de oferecer uma perspectiva teórica à contradição observada na instituição de internação pesquisada, a contribuição de Erving Goffman (1999a) permite também pensar o disciplinamento das condutas a partir da tendência de fechamento e totalização na construção das identidades dos adolescentes internados. Nesse sentido, o encarceramento nessa instituição indica a limitação e um cerceamento imediatos à circulação dos internados, de modo que todos os aspectos de sua vida passam a ser burocraticamente geridos pela instituição.

Por um lado, isso implica a imposição de barreiras às relações sociais domésticas do indivíduo - seu convívio com a família, com a vizinhança, os amigos, os colegas e professores de escola, a turma da rua ou do futebol, etc. interrompendo ou limitando a influência que essas relações poderiam ter na formação da identidade individual. Por outro lado, o encarceramento envolve a concentração das relações socializadoras, apresentadas como ressocializadoras, nos funcionários da instituição de internação e nos demais internados. Assim, tem como conseqüência a produção de um processo socializador diferenciado e totalizador ao restringir bruscamente os tipos de relações sociais e os agentes com

\footnotetext{
${ }^{13}$ Goffman, 1999a:16.

${ }^{14}$ Cf. Goffman,1999a:17-23. Sobre a realização das esferas da vida em lugar distintos, com diferentes co-participantes e autoridades, ver também Goffman, 1999b.

${ }^{15}$ Goffman: 1999a:70.
} 
quem o indivíduo convive cotidianamente. $\mathrm{O}$ efeito desse processo totalizador tende a ser, para os internados, a constituição de identidades estigmatizadas, notadamente condensadas na categoria menor. ${ }^{16}$

Como o disciplinamento torna possível compreender o lugar ocupado pelas famílias dos adolescentes em uma unidade de internação? Ora, a mobilização que ele produz ultrapassa os muros que limitam o espaço institucional, estendendose até às famílias dos adolescentes. Nesse sentido, a cooperação dos familiares é solicitada e avaliada pelos funcionários em duas ocasiões principais, quais sejam, a participação no atendimento familiar e a freqüência nos dias reservados à visita.

O comparecimento dos familiares nessas ocasiões pode demonstrar, para os funcionários, sua vontade de colaborar com a medida socioeducativas recebida por seus filhos e pode acarretar, por conseguinte, uma boa avaliação no relatório semestral. No entanto, dada a situação de seus filhos, as famílias assim convocadas são submetidas a um tratamento específico. Trata-se do contágio pelo crime, ou seja, de uma concepção que classifica os familiares dos adolescentes como infratores em potencial.

Embora não seja comumente externalizada nas falas dos funcionários, essa concepção materializa-se em uma prática rotineira: a revista. Para poderem entrar no estabelecimento, os familiares dos adolescentes são conduzidos a uma sala lateral do pequeno prédio da recepção juntamente com policiais militares. Quando a porta dessa sala se fecha, a revista é realizada por meio do desnudamento dos familiares e do exame de seus corpos nus. O objetivo declarado de tal prática é verificar se não estão levando para seus filhos objetos proibidos pela direção, como substâncias entorpecentes e armas.

Desse modo, a revista parece justificar-se pela prioridade dada à manutenção da ordem dentro do estabelecimento, pois determinados objetos, como armas e drogas, podem gerar desordens, rebeliões e até mortes. No entanto, o que está em jogo não é simplesmente a manutenção da ordem, mas a quem as

\footnotetext{
${ }^{16}$ Uma relevante abordagem teórica sobre estigmatização é também encontrada em Erving Goffman. Cf., Goffman, 1988.
} 
tentativas de perturbação da ordem são associadas. Advogados, juízes, promotores, defensores públicos, funcionários do Estado e estudantes universitários não são revistados.

Uma vez que os revistados são os próprios adolescentes e seus familiares, esses últimos são transformados em "suspeitos" por uma associação não declarada com o ato de infringir a lei. ${ }^{17}$ Essa associação permite delinear a forma como os funcionários concebem o ato infracional, por intermédio da atribuição da qualidade de contágio. Desse modo, o ato infracional não é somente a causa explícita da internação, mas ocasiona também um processo implícito de qualificação contaminadora dos elementos que compunham a vida anterior do adolescente, como os relacionamentos com familiares, amigos, e namorados ou namoradas.

Durante a internação, esses relacionamentos parecem constituir um conjunto de "relações perigosas" que o estabelecimento e seus funcionários devem tratar. O tratamento pode ocorrer tanto na perspectiva de uma interdição completa dos contatos quanto do seu disciplinamento. Nesse sentido, os funcionários tendem a defender a interdição para as relações afetivo-sexuais, aprovando a inexistência de um espaço onde os adolescentes possam receber visitas íntimas.

Contudo, no que se refere às relações familiares, a percepção dos funcionários é mais complexa. Os responsáveis pela manutenção da segurança, os monitores e encarregados de ala, mantêm as relações familiares no registro das "relações perigosas" que associam o adolescente ao ato infracional. Assim, enfatizam a violência doméstica, o abandono, a falta de apoio e de condições financeiras dos pais como características dos adolescentes internados.

Já os funcionários do grupo técnico - pedagogos, assistentes sociais e psicólogos responsáveis pela dimensão pedagógica da internação - vão além de apontar essa "periculosidade" da família, relacionando-a como algo que a instituição deva tratar. Nesse sentido, a família não somente é inserida naquele conjunto de

\footnotetext{
${ }^{17}$ Os adolescentes são revistados assim que chegam ao estabelecimento, como seus familiares; mas também o são, diariamente, antes de saírem das oficinas profissionalizantes para suas alas e antes de entrarem nelas. Pode ocorrer também uma revista extraordinária quando circulam rumores de rebelião.
} 
relações associadas ao ato infracional do internado, como também passa a integrar a atuação pedagógica sobre o adolescente.

\section{São Paulo: da sensação de caos à defesa do Estatuto da Criança e do Adolescente.}

A forma como o grupo técnico delimita o lugar da família na medida socioeducativa de internação, inserindo as relações familiares do adolescente em uma questão de tratamento e não de interdição (como ocorre com as relações afetivo-sexuais), constituiu um primeiro recorte dentro da idéia inicial de estudar a relação entre famílias e instituições responsáveis pela execução de medidas socioeducativas. Nesse sentido, seria relevante pensar como o grupo técnico percebe e se relaciona com as famílias dos adolescentes que cometeram atos ilícitos e quais são as conseqüências dessa percepção e desse relacionamento para elas.

Tendo como base essa questão, suscitada nas pesquisas em Brasília, a proposta inicial foi a de aprofundar a temática da relação entre familiares e grupo técnico na situação específica de internação de adolescentes. Esse aprofundamento seria acompanhado de uma mudança de contexto, ou seja, seria realizado não mais em Brasília, mas no município de São Paulo.

Contudo, o levantamento preliminar de dados apontou para certas particularidades do contexto paulista que não poderiam ser negligenciadas. Pelo contrário, tais particularidades levaram a novos questionamentos e alterações na temática inicial, de tal forma que a construção do problema de investigação foi profundamente influenciada pela mudança de contexto.

Assim, duas questões destacaram-se de imediato e marcaram diferenças em relação à realidade das pesquisas anteriores. Primeiramente, no Estado de São Paulo, a execução das medidas socioeducativas é gerida por um órgão específico, a Febem-SP, cuja estrutura institucional engloba várias unidades 
de internação, semiliberdade e postos de liberdade assistida. No entanto, as informações sobre essa estrutura encontram-se dispersas e, não raro, desconexas, o que gera uma sensação de caos em relação a ela. Em segundo lugar, as formas de gestão adotadas pela Febem-SP são alvo constante de críticas por parte de grupos politicamente engajados na defesa de direitos humanos, que procuram assegurar a implantação das diretrizes do Estatuto da Criança e do Adolescente em São Paulo.

Caracterizada pela dispersão e fragmentação das informações sobre a ampla estrutura da Febem-SP, a sensação de caos constituiu o estranhamento inicial em relação ao contexto paulista. Tal estranhamento aprofundava-se à medida que o levantamento preliminar de dados não conseguia obter informações mais precisas e fundamentais para a organização de um campo de pesquisa sobre a relação entre o grupo técnico e as famílias dos adolescentes que cumprem medida de internação. Dessas informações, foram obtidas somente aquelas referentes ao número de adolescentes atendidos pela Febem-SP e ao número de unidades de internação, não sendo possível dizer quantos técnicos trabalham em cada uma dessas unidades e qual a freqüência com que oferecem atendimento social e psicológico aos adolescentes e suas famílias. ${ }^{18}$

Não obstante, depois de um certo esforço na busca de fontes de dados e da opção por utilizar diferentes tipos de fonte, uma contextualização panorâmica de como e para quem se estrutura a execução das medidas socioeducativas no Estado e no Município de São Paulo pode ser traçada. ${ }^{19}$ Essa contextualização

\footnotetext{
${ }^{18} \mathrm{O}$ número de adolescentes atendidos e o número de unidades de internação serão apresentados na contextualização da estrutura de atendimento deste capítulo. Embora, atualmente, esses números estejam disponíveis no sítio oficial da Febem-SP (www.febem.sp.gov.br), deve-se salientar a dificuldade em encontrar informações detalhadas sobre a estrutura institucional de execução de medidas socioeducativas no Estado de São Paulo. No que se refere aos dados oficiais, o sítio da Febem-SP esteve fora do ar durante os dois primeiros anos desta pesquisa (2001 e 2002) e as informações nele disponíveis estão dispersas e incompletas, dificultando uma visão geral de sua estrutura e impossibilitando o estabelecimento de séries histórico-comparativas de dados. A dispersão e a fragmentação dos dados caracterizam também as informações veiculadas pelos grupos de defesa dos direitos humanos, cujos relatórios mencionam pontualmente aspectos da estrutura institucional com o intuito de denunciar a atuação governamental.

${ }^{19}$ Devido à escassez de dados oficiais, tornou-se necessário o recurso a diferentes tipos de fonte, que foram avaliados e selecionados conforme critérios de credibilidade e postura política. Assim, boa
} 
divide-se em três pontos principais, que procuram contemplar as particularidades observadas no contexto paulista, a saber, a sensação de caos e a defesa do Estatuto da Criança e do Adolescente.

Assim, os dois primeiros pontos referem-se à sensação de caos quanto à estrutura institucional e procuram descrever a população de adolescentes atendidos e suas famílias e a organização dessa estrutura. Já o terceiro visa apresentar os questionamentos a que essa estrutura está sujeita, isto é, a distância entre a atuação da Febem-SP e o que os grupos de defesa dos direitos humanos acreditam ser o ideal preconizado pelo Estatuto. Esse último ponto viabiliza a inserção da temática inicial, da relação entre famílias e técnicos, em uma discussão política sobre os ideais e as práticas de atendimento relativas às medidas socioeducativas, o que é fundamental para a construção deste problema de investigação.

O primeiro ponto a ser abordado remete, então, à população a quem se destina a estrutura de atendimento. Da ótica institucional, a inclusão na FebemSP é a linha de chegada de um circuito que se inicia com a apreensão do jovem pelo aparelho policial e passa pela decisão do sistema de justiça especializado. O registro da ocorrência policial representa a entrada nesse circuito, pois é o momento em que se estabelece a associação entre o adolescente e a atribuição qualitativa "autor de ato infracional", cujos impactos na identidade e na biografia individual serão mais ou menos intensos conforme o tipo e o tempo de duração da medida, determinada pelo sistema de justiça.

Esse sistema começa a atuar na entrevista informal do adolescente com o promotor de justiça, que o questiona sobre o ato infracional, tendo como

parte dos dados utilizados foi conseguida a partir de documentos produzidos por pesquisadores e por grupos de defesa dos direitos humanos. Além desses documentos, citados na bibliografia, destacamse vários informantes, cuja contribuição foi fundamental: um educador social que desenvolveu projeto de organização não-governamental em uma unidade de internação, uma ex-funcionária do grupo técnico da Febem-SP e os membros da Associação das Mães e Amigos da Criança e do Adolescente em Risco - AMAR. Fundada em 1998, a AMAR constituiu-se a partir da iniciativa de mães de jovens internados em unidades da Febem de São Paulo. Seu objetivo central é organizar politicamente as denúncias de maus tratos e torturas sofridos pelos adolescentes, de modo a obter resultados efetivos do Estado no sentido de sanar esse tipo de violência institucional. 
referências documentais o boletim de ocorrência e as informações sobre seus antecedentes. ${ }^{20}$ Após a entrevista, o promotor pode conceder remissão ou pedir o arquivamento dos autos, interrompendo o circuito institucional. ${ }^{21}$ No entanto, o circuito continuará se o promotor oferecer à autoridade judicial uma representação, propondo a aplicação da medida socioeducativa que considerar adequada. Nesse caso, passa-se à etapa das audiências com o juiz, em que se torna obrigatória a presença do advogado e dos pais ou responsáveis pelo adolescente.

A etapa das audiências requer a atuação da tríade básica do sistema de justiça, a saber, o juiz, o promotor e o advogado. Porém, há um quarto grupo de atores que pode aparecer nessa etapa. Quando solicitado pelo juiz, uma equipe interdisciplinar composta por psicólogos, pedagogos, assistentes sociais e/ou médicos elabora um relatório técnico sobre as condições psicológicas, sociais e familiares do adolescente. ${ }^{22}$ Esse relatório visa fundamentar cientificamente a decisão judicial, que determina a medida a ser aplicada dentre as possibilidades gradativamente mais severas de advertência, obrigação de reparar o dano, prestação de serviço à comunidade, liberdade assistida, semiliberdade e internação. ${ }^{23}$

Somente as três últimas são executadas pela Febem-SP, concluindo o circuito. Desse modo, sob a ótica institucional, a população atendida caracteriza-se

\footnotetext{
${ }^{20}$ Embora o Ministério Público e a Advocacia não estejam vinculados ao Poder Judiciário, ambos são funções essenciais à administração da justiça no país. Assim, pode-se dizer que promotores e advogados são partes atuantes no sistema de justiça. Sobre a legislação, ver artigos 127 a 135 da Constituição Federal.

${ }^{21}$ Nesses casos, os autos são considerados conclusos e enviados ao juiz para homologação. Cabe ressaltar que a palavra remissão tem o sentido de perdão ou indulto, implicando a extinção ou a suspensão do processo (art. 188, do Estatuto da Criança e do Adolescente). Sobre os procedimentos de apuração de ato infracional, ver os artigos 171 a 190 do referido Estatuto.

${ }^{22}$ Sobre o conteúdo dos relatórios, ver Passetti, 1999a:106-12.

${ }^{23}$ Cf. artigo 112 do Estatuto da Criança e do Adolescente, que prevê também a possibilidade de aplicação das medidas específicas de proteção previstas pelo artigo 101, incisos I a VI, a saber: encaminhamento aos pais ou responsável, mediante termo de responsabilidade; orientação, apoio e acompanhamento temporários; matrícula e freqüência obrigatória em estabelecimento oficial de ensino fundamental; inclusão em programa comunitário ou oficial de auxílio à família, à criança e ao adolescente; requisição de tratamento médico, psicológico ou psiquiátrico, em regime hospitalar ou ambulatorial; inclusão em programa oficial ou comunitário de auxílio, orientação e tratamento a alcoólatras e toxicômanos.
} 
por adolescentes autores de ato infracional que receberam as medidas de liberdade assistida, semiliberdade ou internação.

Contudo, se consideradas as perspectivas do perfil social dos atendidos e a relação entre o tipo de infração cometida e a medida aplicada, verificase uma dupla tendência seletiva do circuito institucional que leva à Febem-SP. Segundo apontam diversos estudos, os adolescentes provenientes dos segmentos de baixa renda e moradores da periferia dos grandes centros urbanos estão mais propensos a receberem medidas severas do que aqueles provenientes dos segmentos médios ou altos. ${ }^{24}$ Além disso, a liberdade assistida, a semiliberdade e a internação são preferencialmente aplicadas ao roubo, que é uma infração contra o patrimônio. $^{25}$

A tendência seletiva do circuito institucional tem como ponto de partida a ação do aparelho policial, que reproduz do imaginário social uma visão discriminatória da criminalidade na qual os jovens pobres são considerados potencialmente ameaçadores da ordem social. ${ }^{26}$

No entanto, o ponto nevrálgico onde se determina a população a ser recrutada para a Febem-SP é o sistema de justiça juvenil. Com o intuito de avaliar o impacto da promulgação do Estatuto da Criança e do Adolescente nesse sistema, merecem destaque, por seus resultados esclarecedores, duas pesquisas da década de 1990 que utilizaram processos judiciais como fonte de dados. A primeira delas analisa o conteúdo desses processos e assinala os padrões de atuação das instituições e dos atores envolvidos. A segunda pesquisa salienta a relação entre os tipos de infração cometida por adolescentes, seu perfil social e as medidas aplicadas a partir de uma leitura quantitativa dos processos judiciais.

\footnotetext{
${ }^{24}$ Analisando os processos judiciais e a população de adolescentes internados, vários estudos indicam a tendência de punir mais severamente (com internação) os jovens provenientes das classes mais baixas. Dentre esses estudos, cabe citar, em São Paulo, Adorno, Lima \& Bordini, 1999; Adorno, 1991; Kosminsky, 2001; Miraglia, 2001; Oliveira, 1999; Passetti, 1999a; Passetti, 1999b; Rodrigues, 2001; Sales, 2003; Silva, 1991; e, no Rio de Janeiro, Batista, 2003. Essa tendência também se verifica em Brasília, ver Paula, 2000a.

${ }^{25}$ Cf. Adorno, Lima \& Bordini, 1999:50-1.

${ }^{26}$ Cf. Adorno, Lima \& Bordini, 1999:29.
} 
Tendo como fonte processos de adolescentes internados no Estado de São Paulo, entre julho de 1990 e maio de 1993, o grupo de pesquisa coordenado por Edson Passetti (1999a) aponta a tendência expressiva de encarceramento por parte do sistema de justiça juvenil. Não obstante o grupo não ter avaliado a distribuição das medidas, concentrando-se na internação, os resultados obtidos revelam que sua aplicação envolve a convergência entre a solicitação do promotor, a sugestão do relatório técnico e a decisão judicial.

Para o grupo, tais resultados salientam a cumplicidade estabelecida entre o Ministério Público e o juiz, percebida a partir da regularidade com que este nega as alegações do advogado, e também destacam a apropriação do relatório técnico como forma de ancoragem científica da opção pela internação. ${ }^{27}$ Assim, o relatório representa uma justificativa das práticas policial e judicial por intermédio da construção da figura do "delinqüente juvenil". Essa construção implica um olhar enviesado que escrutina a vida do adolescente em busca de aspectos que possam ser considerados negativos ou irregulares. Muitas vezes, esses aspectos são a desestruturação familiar e a associação entre marginalidade e pobreza, revelando que a visão discriminatória sobre o fenômeno da criminalidade não é privilégio do aparelho policial, mas perpassa todo o circuito institucional e elege o adolescente pobre como população a ser internada.

Ainda segundo o grupo coordenado por Edson Passetti (1999a), os atos infracionais que levam à internação tendem a ser aqueles que ameaçam a propriedade privada, sendo que $66 \%$ dos internados analisados cometeram infrações contra o patrimônio, seguidos por 13\% que cometeram infrações contra a vida. Todavia, esses dados não são suficientes para fundamentar a predominância de jovens pobres entre os internados ou para estabelecer uma relação entre seu perfil social, a infração cometida e a medida aplicada.

Nesse sentido, a pesquisa realizada por Sérgio Adorno, Renato Lima e Eliana Bordini (1999) a partir dos processos judiciais dos anos de 1993 a 1996, no

\footnotetext{
${ }^{27}$ Ver Passetti, 1999a:90-157; Oliveira, 1999. Sobre a perspectiva dos operadores do direito, cf. Pietrocolla, Sinhoretto \& Castro, 2000.
} 
município de São Paulo, fornece dados mais completos. ${ }^{28}$ De modo geral, os autores de ato infracional são homens $(86,4 \%)$, em sua maioria da etnia branca $(62,3 \%$, contra $37 \%$ de negros), nascidos no Estado de São Paulo (83,3\%), com idade entre 16 e 17 anos (51,5\%) e cujo nível de escolaridade concentra-se no ensino fundamental $(85,2 \%$, entre completo e incompleto). No que se refere à inserção no mercado de trabalho, embora a maior parte deles seja de inativos (54,5\%), entre estudantes $(33,8 \%)$ e não-estudantes $(20,7 \%)$, há um percentual razoável daqueles que são economicamente ativos $(45,5 \%$, dos quais $36,7 \%$ tinham ocupação e $8,8 \%$ eram desempregados). ${ }^{29}$

As infrações cometidas por esses jovens concentram-se, basicamente, naquelas contra o patrimônio, em particular o roubo $(23,2 \%$, entre $19 \%$ consumados e $4,2 \%$ tentados) e o furto ( $26 \%$, entre $18,4 \%$ consumados e $7,6 \%$ tentados). Das infrações contra a vida, que somam $13,6 \%$ do total, apenas $1,3 \%$ é de homicídio e $0,6 \%$ de tentativa; o restante $(11,7 \%)$ refere-se a lesões corporais, ou seja, a agressões físicas. ${ }^{30}$

Ao cruzar os tipos de infrações cometidas com os dados sociais, essa pesquisa aponta que há adolescentes de diferentes segmentos sociais na composição geral das infrações cometidas e que sua participação dá-se de modos distintos. Assim, infrações como furto e roubo tendem a ser cometidas por aqueles provenientes dos segmentos mais baixos, embora tenha havido um crescimento do número de adolescentes dos segmentos médios envolvidos nesses tipos de infração, dado o crescimento do consumo de drogas entre eles. Já a direção nãohabilitada $(6,5 \%$ do total de infrações) aparece como tipo infracional típico dos segmentos médios e elevados. ${ }^{31}$

Das sentenças aplicadas, a pesquisa aponta que a internação representa apenas uma pequena parcela (1,9\% das sentenças), sendo a liberdade

\footnotetext{
${ }^{28}$ Uma visão panorâmica da aplicação de medidas socioeducativas no país pode ser encontrada na publicação Atendimento ao adolescente em conflito com a lei, do Ministério da Justiça (1998).

${ }^{29}$ Adorno, Lima \& Bordini, 1999:30.

${ }^{30}$ Adorno, Lima \& Bordini, 1999:20.

${ }^{31}$ Adorno, Lima \& Bordini, 1999:38.
} 
assistida mais aplicada (24,2\%). O maior percentual, contudo, concentrou-se nos arquivamentos e remissões (51,9\%). Além disso, verificou-se que, a princípio, a decisão pela internação ou outra medida parece estar relacionada a critérios de gravidade da infração, sendo principalmente aplicada aos autores de roubo e de homicídio. $^{32}$

Porém, ao relacionarem a medida aplicada e o tipo de infração cometida aos dados sociais dos adolescentes, Sérgio Adorno, Renato Lima e Eliana Bordini (1999) assinalam uma variação da sentença judicial conforme os critérios de etnia, escolaridade e inserção no mercado de trabalho do autor de ato infracional, revelando a interferência da clivagem social na distribuição das medidas. Assim, os resultados de sua pesquisa apontam que, independentemente da infração cometida ser ou não violenta, os adolescentes brancos, com maior nível de escolaridade, que têm uma ocupação ou são estudantes têm maior propensão a receberem o arquivamento ou a remissão, ocorrendo o inverso com os negros, de nível mais baixo de escolaridade, desempregados ou não-estudantes. ${ }^{33}$

Por conseguinte, se não é possível afirmar uma tendência generalizada de encarceramento, não deve ser descartada, por outro lado, a hipótese de uma tendência de encarceramento conforme critérios outros que não técnico-jurídicos referentes à gravidade do ato infracional. Sendo o sistema de justiça o ponto onde se determina quem será inserido na Febem-SP, essa pesquisa torna possível dizer que a determinação tende a ser feita de acordo com critérios sociais relacionados ao adolescente.

Esses critérios sociais remontam à visão discriminatória sobre o fenômeno da criminalidade, que envolve o aparelho policial e também o sistema de justiça. Tal visão leva a polícia a direcionar sua atuação de controle social para determinados jovens - negros, de baixa escolaridade, desempregados, inativos, etc. -, os técnicos do sistema de justiça a escrutinarem sua vida em busca de elementos

\footnotetext{
${ }^{32}$ Adorno, Lima \& Bordini, 1999:48-53.

${ }^{33}$ Vale ressaltar que a infração violenta é aquela cometida mediante grave ameaça. Sobre esses dados e as conclusões da pesquisa, cf. Adorno, Lima e Bordini, 1999:52-3.
} 
que viabilizem enquadrá-los na figura do "delinqüente juvenil" e os juízes e promotores a punirem-nos mais severamente, ancorados pelo aval "científico" dos técnicos e pelas informações criminais produzidas pela polícia.

Ademais, tais critérios parecem apontar a existência de uma concepção, compartilhada pelos operadores do sistema de justiça, na qual a figura do "delinqüente juvenil" relaciona a situação de pobreza vivida por determinados indivíduos a falhas do seu processo de socialização. Assim, a interferência da baixa escolaridade, do desemprego ou da inatividade econômica na distribuição de medidas mais severas e, conseqüentemente, no encaminhamento para a Febem-SP indica, por um lado, a escolarização e a inserção no mercado de trabalho como eixos socializadores valorizados pelos operadores do sistema de justiça. Por outro lado, indica também que a não-inserção nesses é vista como um acréscimo do "potencial ofensivo" individual, ou seja, aqueles que estão fora dos eixos valorizados são considerados mais "perigosos" para a sociedade.

O resultado dessa distribuição desigual das punições pode ser observado no perfil de adolescentes que completam o circuito institucional, recebendo as medidas mais severas do Estatuto da Criança e do Adolescente, e entram na Febem-SP. Nesse sentido, é ilustrativo um levantamento feito no final da década de 1990 pela instituição, em parceria com a Faculdade de Saúde Pública da Universidade de São Paulo, com o objetivo de caracterizar as famílias de origem de adolescentes internados. ${ }^{34}$

Segundo o levantamento, $50,3 \%$ das famílias de adolescentes internados eram compostas por casal com filhos - sendo o casal original (pai e mãe) ou recomposto (mãe e padrasto, pai e madrasta) - e 13,3\% por mulher com filhos. Assim, as famílias de origem dos adolescentes internados seguiam as tendências de composição familiar do restante da população paulista apontadas pelos resultados da Pesquisa de Condições de Vida (PCV), realizada pela Fundação Sistema Estadual de Análise de Dados e Estatística - Seade, em 1994. ${ }^{35}$ Nessa última, 50\%

\footnotetext{
${ }^{34}$ Cf. Fundação Estadual do Bem-Estar do Menor \& Faculdade de Saúde Pública, 1998.

${ }^{35}$ Cf. Fundação Estadual do Bem-Estar do Menor \& Faculdade de Saúde Pública, 1998:35-7.
} 
das famílias na Região Metropolitana de São Paulo eram compostas por casal com filhos e $13,3 \%$ por mulheres com filhos.

Mesmo sendo a maior parte das famílias dos adolescentes internados compostas pelo casal com filhos, os dados do levantamento coletados nos prontuários apontaram que a presença da mãe tende a ser predominante na situação de internação.

No entanto, os dados do mesmo levantamento referentes à escolaridade, à atividade econômica exercida e ao nível de renda apontaram para a predominância de famílias de segmentos populares entre os adolescentes em situação de internação. ${ }^{36}$ Sobre a escolaridade dos membros adultos, $56,91 \%$ haviam cursado até a quarta série do ensino fundamental (período escolar referente ao antigo primário). Essa baixa escolaridade refletiu-se nos tipos de atividade econômica desses membros, pois a maior parte situou-se em atividades de baixa qualificação profissional, como serviços domésticos $(11,9 \%)$, construção civil $(10,0 \%)$ e prendas domésticas $(12,62 \%)$. Já o nível de renda das famílias, relacionado à baixa escolaridade e às atividades econômicas pouco qualificadas, apresentou maior concentração entre as faixas de 01 a 03 salários mínimos $(27,4 \%)$ e de 03 a 05 salários mínimos $(24,7 \%)$.

A partir desses dados, nota-se que, em sua maioria, os adolescentes internados na Febem-SP são provenientes de famílias que ocupam os setores menos privilegiados da população. Assim, os dados do perfil social dessas famílias são coerentes com aqueles obtidos sobre os adolescentes nas pesquisas sobre o sistema de justiça e apontam quem seria o "público alvo" da estrutura de atendimento das medidas de internação, semiliberdade e liberdade assistida: são os jovens provenientes das famílias de trabalhadores de baixa renda, com pouca qualificação profissional e baixa escolarização, e que, enfim, residem na periferia. Assim, a estrutura organiza-se em torno do atendimento a esses que, embora não

\footnotetext{
${ }^{36}$ Ver também Sales, 2003:50.
} 
sejam os únicos a cometer atos infracionais, são os preferencialmente punidos com medidas mais severas.

Segundo a Febem-SP, em julho de 2004, a população de autores de ato infracional inserida em programas socioeducativos de privação de liberdade e liberdade assistida era de 18.000 adolescentes, entre 12 e 18 anos, em todo o Estado. Desses, 6.400 , ou $35,55 \%$ do total, estavam no chamado circuito fechado, isto é, cumprindo medida de internação, do que se conclui que 11.600 , ou $64,44 \%$, estivessem cumprindo medidas de liberdade assistida ou de semiliberdade, tida como uma espécie de transição do regime fechado para o regime aberto. ${ }^{37}$

O segundo ponto desta contextualização refere-se, justamente, à organização dessa estrutura administrativa construída para atender os adolescentes. Criada em 1976, pela Ditadura Militar, com o intuito de prevenir a "marginalização social de menores abandonados e infratores" por intermédio de seu encaminhamento para unidades de internação, a Febem-SP se manteve, após o processo de redemocratização do país e da promulgação do Estatuto da Criança e do Adolescente, como a instituição estadual responsável pela execução de medidas socioeducativas, não obstante todas as críticas e denúncias feitas a ela nesses quase 30 anos de existência. Sua estrutura de atendimento conta com 9.028 cargos, dos quais 7.631 são permanentes e 1.397 são de confiança, ou seja, são ocupados de acordo com a nomeação do presidente. ${ }^{38}$

Das 77 unidades de internação que existem atualmente no Estado, a maior parte está concentrada na Capital (42 ou 54,55\%), dificultando as visitas aos filhos internados pelas famílias do interior. ${ }^{39}$ Além disso, como demonstra o mapa fornecido pelo sítio oficial da instituição, essas e as de semiliberdade aglomeram-se

\footnotetext{
${ }^{37}$ Conforme relatório da Anistia Internacional (2000:6), o número de adolescentes no circuito fechado, em julho de 2000, apresentava o montante de 4.000, de modo que houve, nos últimos quatro anos, um crescimento de $60 \%$ na população de internados. Contudo, uma vez que a dispersão e a ausência de dados caracterizam essa questão, não é possível completar uma série histórica comparativa, pois não foram encontrados os dados da população geral em julho de 2000. O dados de 2004 foram coletados dia 26 de julho, no sítio www.febem.sp.gov.br.

${ }^{38} \mathrm{Cf}$. anexo do Decreto 47.129, de 24 de setembro de 2002, no sítio www.imprensaoficial.com.br.

${ }^{39}$ Os dados sobre as unidades de internação foram coletados em 26 de julho de 2004, no sítio www.febem.sp.gov.br.
} 
na Zona Leste, principalmente nos bairros mais próximos do centro, como Brás, Belém, Móoca e Tatuapé (ver mapa 1). Não obstante ser a Zona Sul a maior da Capital, é a única das regiões do mapa em que não há unidades nos bairros mais periféricos. Ademais, as poucas unidades nessa região estão concentradas em bairros mais centrais. O contrário pode ser dito da região referente à Zona Oeste, onde as unidades existentes estão em Raposo Tavares, bairro distante do centro. Enfim, na Zona Norte, parece haver maior distribuição espacial. 
Mapa 1: Distribuição das unidades de internação e semiliberdade da Febem-SP no município de São Paulo.

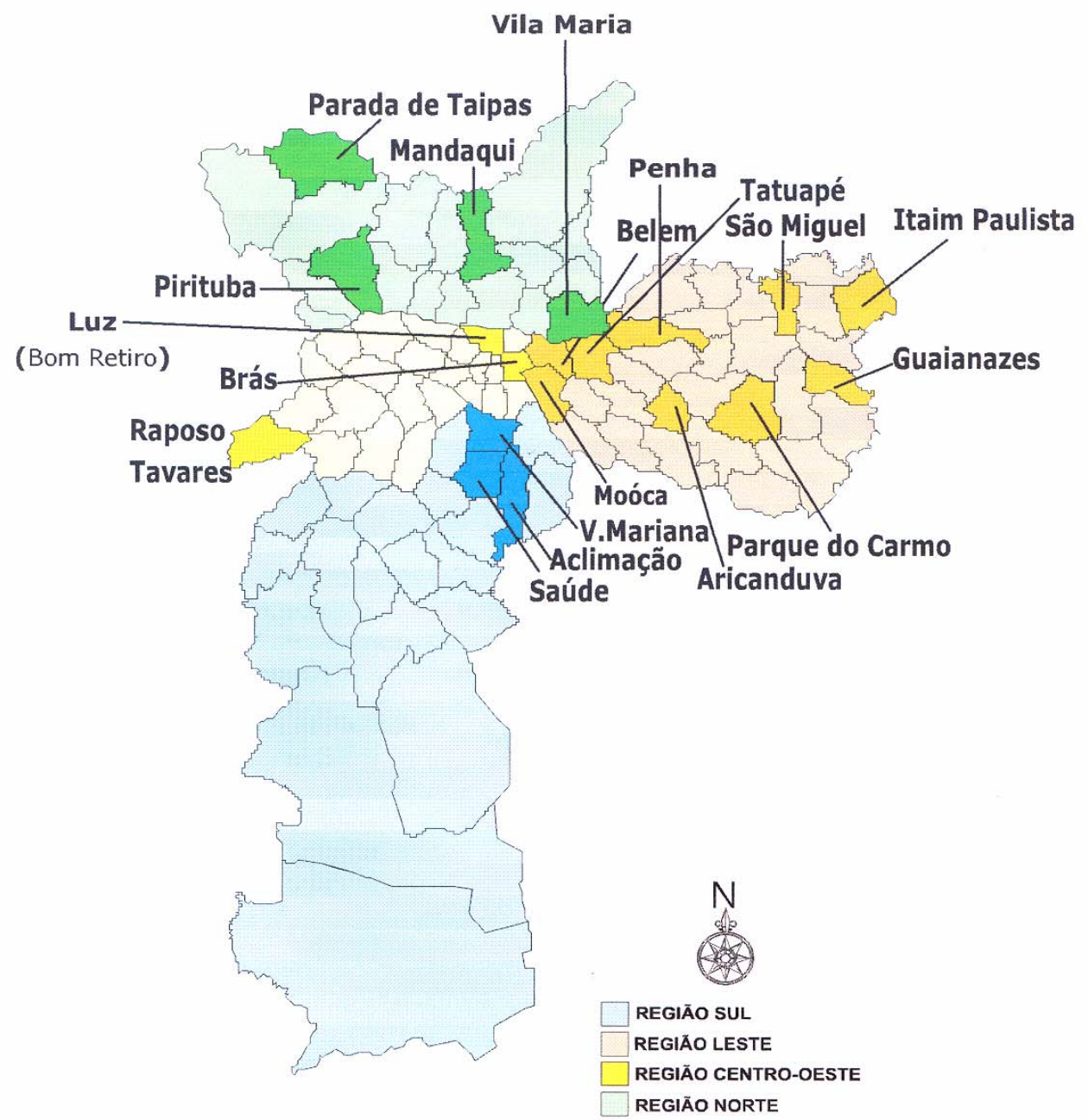

BANCO DE DADOS - GAR/ 2002

Fonte: sítio da Fundação Estadual do Bem-Estar do Menor de São Paulo, www.febem.sp.gov.br, em 26/07/2004. 
A partir do mapa e das informações do sítio, foi feito um quadro para detalhar a distribuição das unidades na Capital (ver quadro 1). Dentre essas, está a Unidade de Atendimento Inicial - UAI, que recebe os adolescentes apreendidos pela polícia para, então, distribuí-los entre as Unidades de Internação Provisória - UIP. Tanto estas quanto a UAl estão aglomeradas no Complexo Brás, que se localiza no mesmo bairro onde funcionam as Varas Especiais da Infância e da Juventude. ${ }^{40}$

A Unidade de Atendimento Inicial e as Unidades de Internação Provisória são voltadas para o atendimento de adolescentes em caráter provisório. Dito de outro modo, nelas estão internados aqueles que ainda não receberam sentença e, por isso, sua internação ainda não constitui medida socioeducativa. Portanto, são unidades de passagem, que servem de porta de entrada para a estrutura de atendimento da Febem-SP.

Além dessa porta de entrada, estão as Unidades de Internação - UI propriamente ditas, nas quais os adolescentes se encontram cumprindo medida de privação de liberdade. Como indicado no mapa acima, no município de São Paulo, a maioria das unidades desse tipo está concentrada na Zona Leste, sendo 18 delas conglomeradas no chamado Complexo Tatuapé, destinado a jovens do sexo masculino. Aparentemente, a única unidade feminina de internação é o Internato da Móoca, sendo as demais unidades femininas de internação provisória, também na Móoca, e semiliberdade, na Móoca, em São Miguel e na Aclimação, centro-sul da Capital. Na Zona Sul, em contrapartida, não funciona nenhuma unidade de internação, havendo apenas três unidades de semiliberdade (ver quadro 1). ${ }^{41}$

\footnotetext{
${ }^{40}$ Além das quatro Unidades de Internação Provisória do Complexo Brás, há também a Unidade Tietê (Vila Maria I), que trabalha com internação tanto provisoriamente quanto como medida socioeducativa, e a Unidade Feminina de Internação Provisória Chiquinha Gonzaga, que funciona na Mooca. Ver quadro 01

${ }^{41}$ Segundo Mione Sales (2003), em 1999, havia vinte e duas unidades de internação operando em São Paulo. Já o relatório da IV Caravana Nacional dos Direitos Humanos da Câmara dos Deputados (2000) assinalava a existência de vinte e três unidades no Complexo do Tatuapé, das quais uma parte estaria inativa. Ainda assim, pode-se dizer que esse complexo é o maior conglomerado de unidades de internação em atividade.
} 
Quadro 1: Distribuição das unidades da Febem no município de São Paulo

\begin{tabular}{|c|c|c|}
\hline & Unidades de internação & Unidades de semiliberdade \\
\hline Região Norte & 06 unidades. & 02 unidades. \\
\hline Mandaqui & & $\begin{array}{l}\text { Casas Comunitárias Região Norte } \\
\text { - Mandaqui e Zunkeller. }\end{array}$ \\
\hline Parada de Taipas & Internato Parada de Taipas & \\
\hline Pirituba & Unidade de Internação Pirituba. & \\
\hline Vila Maria & $\begin{array}{l}\text { Unidade Tietê (Vila Maria I), } \\
\text { Unidade Adoniran Barbosa (Vila } \\
\text { Maria II), Unidades de Internação } \\
\text { Uirapuru (Ul-40) e Abaetê (UI-41). }\end{array}$ & \\
\hline $\begin{array}{l}\text { Região Centro- } \\
\text { Oeste }\end{array}$ & 13 unidades. & 03 unidades. \\
\hline Complexo Brás & $\begin{array}{l}\text { Unidade de Atendimento Inicial } \\
\text { Jaguari, Unidades de Internação } \\
\text { Provisória Itaparica, Rio Paraná, } \\
\text { Juquiá e Rio Turiassu, Unidades } \\
\text { de Internação Rio Sena, Rio São } \\
\text { Francisco e Rio Tâmisa. }\end{array}$ & $\begin{array}{l}\text { Unidade de Semiliberdade Brás, } \\
\text { Espaço } \\
\text { Profissionalizante. }\end{array}$ \\
\hline $\begin{array}{l}\text { Complexo Raposo } \\
\text { Tavares }\end{array}$ & $\begin{array}{l}\text { Unidades de Internação Ipê, } \\
\text { Nogueira, Jatobá, Aroeira e Cedro. }\end{array}$ & \\
\hline Luz (Bom Retiro) & & $\begin{array}{l}\text { Unidade de Semiliberdade de } \\
\text { Progressão. }\end{array}$ \\
\hline Região Sul & & 03 unidades. \\
\hline Aclimação & & $\begin{array}{lll}\text { Unidade } & \text { de } & \text { Semiliberdade } \\
\text { Feminina. } & & \\
\end{array}$ \\
\hline Vila Mariana & & $\begin{array}{l}\text { Casa Comutária Região Sul - } \\
\text { Araré. }\end{array}$ \\
\hline Saúde & & $\begin{array}{l}\text { Casa Comutária Região Sul - } \\
\text { Guararema. }\end{array}$ \\
\hline Região Leste & 23 unidades. & 04 unidades. \\
\hline Aricanduva & & $\begin{array}{l}\text { Casa Comunitária Região Leste - } \\
\text { Aricanduva }\end{array}$ \\
\hline Belém & & Unidade de Semiliberdade Inicial. \\
\hline Complexo Tatuapé & 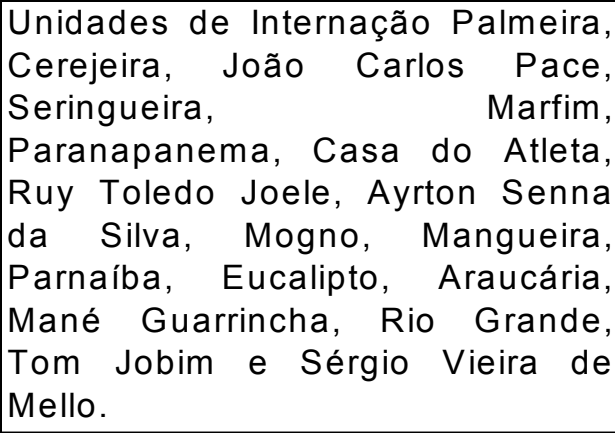 & \\
\hline Guaianazes & Internato Vila Conceição. & \\
\hline Itaim Paulista & Internato Encosta Norte. & \\
\hline Móoca & $\begin{array}{l}\text { Unidade de Internação Provisória - } \\
\text { Chiquinha Gonzaga (feminina), } \\
\text { Internato Feminino da Móoca. }\end{array}$ & 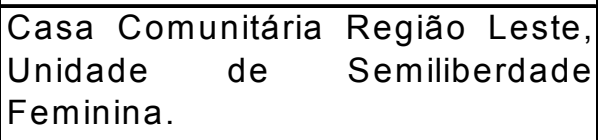 \\
\hline Parque do Carmo & Internato Fazenda do Carmo. & \\
\hline Penha & & Casa Comunitária Região Leste - \\
\hline São Miguel & & $\begin{array}{l}\text { Casa Comunitária Sossóia } \\
\text { (feminina). }\end{array}$ \\
\hline
\end{tabular}

Fonte: sítio da Fundação Estadual do Bem-Estar do Menor de São Paulo, www.febem.sp.gov.br em 26/07/2004. 
O Complexo Tatuapé não é o único conglomerado de unidades de internação em atividade. ${ }^{42}$ Além dele e do Complexo Brás, voltado para a internação em caráter provisório, há também o Complexo Raposo Tavares, na Zona Oeste, com cinco unidades de internação. Também, havia, até recentemente, o de Franco da Rocha, construído, após a rebelião de 1999, na região metropolitana de São Paulo para abrigar adolescentes considerados de "alta periculosidade". 43 Esse complexo foi bastante noticiado desde janeiro deste ano, devido às rebeliões, às denúncias de maus tratos e da facilitação de rebeliões pelos monitores.

Além dos maus tratos - que não eram exclusividade do complexo de Franco da Rocha, mas são denunciados em boa parte das unidades de internação da Febem-SP -, a tortura, a superlotação e a ausência ou deficiência de atividades socioeducativas formam a marca registrada do atendimento fornecido aos adolescentes de São Paulo. Assim, continuam presentes as mesmas questões que alimentaram a violenta rebelião de 1999, distanciando, e muito, o atendimento da Febem-SP daquilo que o Estatuto da Criança e do Adolescente prevê como o ideal.

Por fim, o terceiro ponto a ser destacado nesta contextualização referese, justamente, aos questionamentos a que a estrutura de atendimento paulista está submetida. Nesse sentido, a existência de complexos, principalmente o do Tatuapé, é um dos alvos das constantes disputas entre os grupos de defesa dos direitos humanos e o governo do Estado. ${ }^{44}$ Para esses grupos, o governo tem demonstrado estar alheio às determinações do Estatuto, agindo de modo arbitrário na resolução das crises na estrutura de atendimento da Febem-SP.

Segundo esses grupos, as ações governamentais não estariam focalizando a problemática da infância e da adolescência em sua especificidade.

\footnotetext{
42 Até 1999, havia o complexo da rodovia dos Imigrantes, desativado após a rebelião tratada anteriormente. $\mathrm{Na}$ época, os adolescentes foram transferidos para o Centro de Observação Criminológica do Carandiru, o Cadeião de Santo André, o Cadeião de Pinheiros, o Presídio de Parelheiros e para Franco da Rocha. Cf. Anistia Internacional, 2000:13-22.

${ }^{43}$ Com a desativação do Complexo Franco da Rocha, a atribuição de receber adolescentes "perigosos" ou reincidentes graves parece ter sido transferida para a Unidade Adoniran Barbosa (Vila Maria III). Ver www.febem.sp.gov.br.

${ }^{44}$ Embora referida a crianças e adolescentes nas ruas, uma interessante abordagem da relação entre as entidades não-governamentais e o Estado é encontrada em Gregori, 2000.
} 
Antes, estariam inserindo-a no modelo punitivo carcerário destinado aos adultos. A transferência de adolescentes para o sistema prisional, a construção de novos complexos, a própria existência desses complexos e sua centralização na capital do Estado são citadas como ações que negam o atendimento previsto pelo Estatuto.

As críticas feitas pelos grupos de defesa dos direitos humanos às ações governamentais baseiam-se, portanto, em três diretrizes de atendimento estabelecidas a partir do Estatuto. Primeiramente, está a descentralização, em que são abolidos os grandes complexos de unidades concentrados na capital para a construção de unidades menores espalhadas por todo o Estado. O objetivo é, por um lado, manter o adolescente o mais próximo possível de sua família e comunidade de origem e, por outro, diminuir o poder político-administrativo do governo do Estado, com o aumento da participação dos municípios e da sociedade civil organizada.

Em segundo lugar, está a desinstitucionalização, ou seja, a nãointernação e a desinternação. ${ }^{45}$ Evitando internar ou manter a internação do adolescente até seu limite, o objetivo é fortalecer as outras medidas socioeducativas, chamadas de "medidas em meio aberto", para se contraporem ao ambiente fechado e murado característico das unidades de internação. Contudo, a internação não deixa de existir enquanto medida, mas passa a operar em caráter de excepcionalidade, estando reservada aos adolescentes que cometeram ato infracional mediante grave ameaça, que voltaram a cometer ato infracional após cumprirem medida socioeducativa ou que não concluíram o cumprimento de outra medida.

Em terceiro lugar, tem-se a individualização, segundo a qual o atendimento ao adolescente autor de ato infracional deve levar em consideração sua

\footnotetext{
${ }^{45}$ Com a desinstitucionalização, a crítica dos grupos de defesa dos direitos humanos direciona-se menos ao governo do Estado, que executa as medidas, e mais ao Poder Judiciário, que as estabelece. A tendência de aprisionamento, ou melhor, de internação nas sentenças do Judiciário, não somente contraria o caráter de excepcionalidade reservado a esse tipo de medida, mas também revela uma atitude conservadora (e repressiva/ punitiva) ante o adolescente em conflito com a lei. Sobre a tendência de aprisionamento, ver Passetti, 1999a; Sales, 2003.
} 
especificidade enquanto categoria sociojurídica e enquanto indivíduo. ${ }^{46} \mathrm{~A}$ especificidade da categoria sociojurídica adolescente insere-o na concepção mais ampla de pessoa em desenvolvimento, sujeito de direitos e detentor de absoluta precedência por parte da família, da sociedade e do Estado. ${ }^{47}$ Já a especificidade enquanto indivíduo significa que a medida socioeducativa deve levar em consideração as características particulares de cada adolescente, fornecendo-lhe o atendimento técnico - médico, odontológico, psicológico, assistencial e pedagógico - mais pertinente.

Uma vez que a concepção da criança e do adolescente como sujeitos de direito e a afirmação de sua condição peculiar de pessoas em desenvolvimento são consideradas as bases sobre as quais se constrói a doutrina da proteção integral e se fundamenta o Estatuto da Criança e do Adolescente, a diretriz da individualização parece ser a mais central, pois é a partir dela que se busca assegurar a concretização dessas bases no atendimento e, assim, conferir sentido às outras diretrizes. ${ }^{48}$ Desse modo, o atendimento pensado para contemplar as especificidades do adolescente, ou seja, a constituição de um atendimento individualizado serve para legitimar tanto a desinstitucionalização, pois nem todos os adolescentes autores de ato infracional precisam ser internados, quanto a descentralização, que aproxima a estrutura de atendimento do contexto vivido pelos adolescentes.

Nesse sentido, a defesa da individualização do atendimento e o empenho em demonstrar que a Febem-SP não consegue implementá-la colocam em pauta a descentralização e a desinstitucionalização na execução das medidas socioeducativas em São Paulo. Com isso, as propostas dos grupos de defesa dos

\footnotetext{
${ }^{46}$ A discussão sociológica sobre o processo de individualização e o conceito de indivíduo pode ser vista em Augusto, 2002 e Augusto, 1995.

${ }^{47}$ Grosso modo, o Estatuto da Criança e do Adolescente fundamenta-se na doutrina da proteção integral, formulada pela Organização das Nações Unidas, que caracteriza a criança e o adolescente a partir de seu valor intrínseco como ser humano, de seu valor inestimável como pessoa em desenvolvimento, de seu valor prospectivo como continuidade do seu povo e da Humanidade e de sua cidadania especial por sua natureza in fieri. Com isso, a criança e o adolescente são merecedores de proteção integral (física, psíquica, moral), devido à sua vulnerabilidade, e de políticas específicas e prioritárias de promoção e defesa de direitos. (Brasil criança urgente: a lei, 1994:17-8).

${ }^{48}$ Brasil criança urgente: a lei, 1994:11.
} 
direitos humanos direcionam-se para a desarticulação da estrutura de atendimento centralizada na Febem-SP e para a adoção, em larga escala, das medidas socioeducativas em meio aberto, que são desinstitucionalizadas, não envolvendo internação, e descentralizadas, sendo realizadas em locais próximos ou na própria comunidade de origem dos adolescentes. ${ }^{49}$

Se há, por um lado, a tendência prisional como forma de atendimento das unidades de internação da Febem-SP, existe, por outro, a tendência de que esse atendimento seja colocado em confrontação e até em negociação com os grupos de defesa dos direitos humanos, como é o caso das medidas em meio aberto. Com isso, travam-se intensas disputas políticas entre as formas de ação do governo do Estado e as propostas desses grupos, que alegam pautar-se pelo Estatuto.

Enfim, a sensação de caos na organização do atendimento aos adolescentes autores de ato infracional e as disputas políticas entre os grupos de defesa dos direitos humanos e o governo do Estado, com vitórias parciais e lutas permanentes para ambos, são as particularidades que mais se destacaram no contexto paulista. Foram elas, a sensação de caos e a defesa do Estatuto, que levaram esta pesquisadora a uma reformulação na abordagem da relação entre as famílias dos adolescentes e as instituições responsáveis pelas medidas socioeducativas.

\footnotetext{
${ }^{49}$ A descentralização e a desinstitucionalização aparecem em movimentações político-sociais como a da "municipalização" do atendimento da liberdade assistida (l.a.). Por intermédio de convênios, a Febem tem deixado de executar diretamente essa medida, limitando-se a coordenar e supervisionar entidades da sociedade civil a ela conveniadas. Contudo, essa "municipalização", tal como proposta por organizações não-governamentais e de defesa dos direitos humanos está mais próxima de uma publicização do atendimento do que da municipalização propriamente dita, pois concentra-se na participação da comunidade e da sociedade civil. Sobre a proposta de municipalização, cf. Unicef et alii, [s/d].
} 


\section{Repensando a família no contexto paulista.}

De modo geral, a sensação inicial de caos na forma como o atendimento das medidas socioeducativas se estrutura em São Paulo foi amenizada pelas informações coletadas de diversas fontes e apresentadas anteriormente. Contudo, pouco se conseguiu avançar no que se refere especificamente ao atendimento técnico-familiar, que seria fundamental para pensar a relação entre técnicos de unidades de internação e familiares de adolescentes internados.

Por um lado, o estudo dessa relação era bastante pertinente na unidade de internação pesquisada no Distrito Federal, onde os técnicos eram vistos, diariamente, inserindo os familiares dos adolescentes em variadas formas de atendimento. Dessa forma, a presença de familiares na instituição não se restringia aos dias de visita ou aos momentos de rebelião. Pelo contrário, eles participavam de atividades coordenadas pelos técnicos, como reuniões individuais - somente com os familiares ou com familiares e seus filhos - e grupos de discussão, formados por vários familiares e seus filhos.

Por outro lado, as poucas informações encontradas em São Paulo levavam a crer que $\mathrm{o}$ atendimento técnico-familiar era uma prática rara, quase escassa, nas unidades da Febem-SP - o que abalava, profundamente, a proposta de pensar a relação entre os técnicos e os familiares. Como seria possível estudar uma relação que parecia ser quase inexistente? Como pensar em uma relação que, já sendo considerada como secundária na situação de internação, se tornava quase irrelevante diante da urgência impressa pela violência institucional e da prioridade concedida à relação entre monitor e adolescente?

A realidade depreendida das fontes pesquisadas parecia obscurecer a importância da relação entre famílias e técnicos. De certo modo, ela seria secundária de antemão, pois, no universo das medidas socioeducativas, o que há de mais relevante é o próprio adolescente. Nesse sentido, embora seja estruturada a partir 
do adolescente, a relação entre familiares e técnicos não o envolve diretamente, sendo, por isso, secundária. ${ }^{50}$

Ainda assim, o atendimento técnico-familiar pode ser um indicativo relevante das práticas institucionais pelas quais é concebido o tratamento ideal ao adolescente autor de ato infracional. Dessa feita, ao contrário do que se poderia supor a princípio, a relação das famílias com os técnicos ou, mais do que isso, com as instituições responsáveis pela execução das medidas socioeducativas, como a Febem-SP, é extremamente pertinente em um contexto tão politizado como o paulista. Nesse contexto, o atendimento técnico-familiar converte-se em um elemento a ser utilizado na disputa política entre aqueles que procuram desacreditar essa instituição e os que procuram defendê-la.

Entre os argumentos para justificar a ausência de um atendimento técnico-familiar regular, pode-se citar o tamanho da população atendida. Considerando somente os adolescentes internados, aproximadamente 6.400 famílias seriam atendidas, semanal ou quinzenalmente. Além disso, há também os adolescentes em semiliberdade e liberdade assistida. Tudo somado, o fornecimento de atendimento técnico-familiar significaria um aumento sensível de cargos e gastos para atender a 18.000 famílias.

Para os que defendem o Estatuto da Criança e do Adolescente, o atendimento técnico-familiar tem de ser implantado. Assim, a proposta parece ser a redução do número de adolescentes internados - ou seja, o combate à tendência de aprisionamento - e o aumento do número de adolescentes em liberdade assistida. Como a estrutura da Febem-SP não consegue atender a esses últimos, a idéia que vem sendo implementada é a de distribuí-los entre entidades da sociedade civil que,

\footnotetext{
${ }^{50}$ Mesmo na Febem-SP, o adolescente em conflito com a lei ocupa uma posição central, pois, sem ele, a instituição não poderia justificar sua existência na sociedade. Assim, as relações institucionais são estruturadas a partir dele, podendo ser tanto primárias, quando o envolvem diretamente, quanto secundárias. As relações institucionais primárias são estabelecidas entre o adolescente e os técnicos, os monitores, outros adolescentes, os seus familiares.
} 
em convênio com ela e, sob sua supervisão, executariam a medida de liberdade assistida. $^{51}$

Por não implicar o encarceramento, essa medida é tida como uma das formas de operacionalizar a diretriz de desinstitucionalização do atendimento no sentido da não-internação. Como sua implementação tem-se dado a partir de convênios com entidades da sociedade civil, pode-se dizer que a descentralização tem sido alcançada, pois a Febem-SP deixa de atuar diretamente e passa a supervisionar a atuação dessas entidades. Por sua vez, elas são designadas por estarem mais próximas do adolescente e sua comunidade de origem. Enfim, a liberdade assistida é também uma medida mais individualizada e individualizadora, pois essas entidades trabalham com um número de adolescentes adequado à sua capacidade. Assim, podem fornecer regularmente, dentre outros, o atendimento técnico-familiar exigido.

Contra a internação e sua violência intrínseca, a desinternação como prioridade; contra a ineficiência da centralização político-administrativa, a descentralização e a redistribuição de poderes com entidades conveniadas da sociedade civil; contra a massificação, um atendimento individualizado - a liberdade assistida parece resolver todos os problemas colocados pela Febem-SP ao longo de seus quase trinta anos de existência e enquadrar o Estado de São Paulo nas diretrizes do Estatuto da Criança e do Adolescente. No entanto, e não obstante a realidade violenta do atual atendimento fornecido, essa tendência de valorização da liberdade assistida coloca novas questões referentes à relação entre famílias e instituições responsáveis pela execução das medidas socioeducativas.

Para delimitar melhor essas questões, deve-se recorrer ao próprio Estatuto, pois são suas diretrizes que levam à valorização da liberdade assistida e, por conseguinte, do atendimento técnico-familiar. Ali, esse atendimento é previsto como parte integrante da liberdade assistida e também da internação, revelando que

\footnotetext{
${ }^{51}$ Cabe ressaltar que a Febem-SP conta com apenas quatro postos - Norte, Sul, Leste e Oeste para execução da liberdade assistida.
} 
a socioeducação da pessoa em desenvolvimento é concebida como uma reeducação de suas relações familiares.

De modo geral, o Estatuto da Criança e do Adolescente estrutura-se a partir do artigo 277 da Constituição Federal, no qual se asseguram, a crianças e adolescentes, o direito à vida, à saúde, à alimentação, à educação, ao lazer, à profissionalização, à cultura, à dignidade, ao respeito, à liberdade e à convivência familiar e comunitária. O primeiro livro do Estatuto dedica-se, justamente, a regulamentar cada um desses direitos, considerados como fundamentais. Sua garantia é, tanto para o Estatuto quanto para a Constituição, dever da família, da sociedade e do Estado.

A definição da socioeducação encontra-se no segundo livro, que visa estabelecer as políticas específicas de atendimento a crianças e adolescentes considerados em situação de risco social e pessoal, a saber, as vítimas e os autores de ato infracional. ${ }^{52}$ Esse livro regulamenta as formas de atendimento, a estrutura e o funcionamento das entidades, as instâncias colegiadas de participação da sociedade, as medidas de proteção às vítimas, o sistema de justiça juvenil e as medidas socioeducativas.

Inseridas na doutrina da proteção integral e direcionadas aos adolescentes considerados em situação de risco social e pessoal, as medidas socioeducativas apresentam um duplo caráter. ${ }^{53}$ Por um lado, há a dimensão punitiva, que prevê uma penalidade compulsória diante do cometimento de ato infracional. Ao definir esse ato como a conduta descrita como crime ou contravenção penal, o Estatuto estabelece uma íntima relação com o Código Penal, fazendo deste a base sobre a qual se edifica a socioeducação. ${ }^{54}$ Por outro lado, há essa dimensão pedagógica que, ao conceber o adolescente como uma pessoa em desenvolvimento, procura assegurar que a punição seja educativa.

\footnotetext{
${ }^{52}$ Cf. Brasil criança urgente: a lei, 1994.

${ }^{53}$ Cabe lembrar que a doutrina da proteção integral implica a concepção do adolescente enquanto sujeito de direitos e a afirmação de sua condição especial de pessoa em desenvolvimento como formas de garantir e legitimar sua proteção integral pela família, pela sociedade e pelo Estado.

${ }^{54}$ Art. 103 do Estatuto da Criança e do Adolescente. Uma discussão crítica sobre a relação entre o Estatuto e o Código Penal pode ser encontrada em Passetti, 1999a.
} 
Em termos específicos, a re-educação ou socioeducação pode significar uma simples advertência, a obrigação de reparar o dano ou a prestação de serviços à comunidade, que são medidas leves, realizadas em meio aberto, e nas quais a família do autor de ato infracional não é mencionada. ${ }^{55}$ Aparentemente inócuas no que se refere às relações familiares dos adolescentes, essas medidas envolvem uma visão quase "paternal" da autoridade judicial, que pode "dar uma bronca" - sendo a advertência uma admoestação verbal - ou dar uma "lição" mais pragmática, fazendo com que o adolescente restitua o prejuízo causado à vítima ou trabalhe gratuitamente em tarefas de interesse geral. ${ }^{56}$ Porém, a "lição" a ser aprendida torna-se progressivamente mais severa, com as medidas que envolvem a inserção na Febem-SP e que requisitam a participação da família no processo socioeducativo.

Segundo o Estatuto, a liberdade assistida, medida intermediária em termos de severidade, consiste na designação, por parte do juiz, de uma pessoa capacitada para acompanhar, auxiliar e orientar o adolescente. A primeira incumbência desse orientador é promover socialmente o adolescente e sua família, fornecendo-Ihes orientação e inserindo-os, se necessário, em programa oficial ou comunitário de auxílio e assistência social. ${ }^{57}$ As outras são supervisionar a escolarização, assegurar a profissionalização do adolescente e apresentar relatório do caso à autoridade judicial.

Logo na primeira incumbência, a regulamentação da liberdade assistida apresenta um recorte social implícito de quem seriam os adolescentes para os quais essa medida se aplicaria. Uma vez que a orientação individual e familiar como forma de promoção social não delimita seu significado, a inserção em

\footnotetext{
${ }^{55}$ Cabe lembrar que a única medida em regime fechado é a internação, sendo todas as demais em meio aberto. Talvez uma exceção deva ser feita à semiliberdade, que é um híbrido entre os dois tipos de medida.

${ }^{56}$ Respectivamente, artigos 115 e 117 do Estatuto da Criança e do Adolescente. A idéia de que a medida socioeducativa seja uma "lição" faz-se presente desde as audiências com o juiz. Como assinala Paula Miraglia (2001:82-3), o objetivo das audiências parece ser o de dar uma "lição". (...) Em diversas ocasiões, o juiz acaba fazendo parentes e adolescentes chorarem, "pela vergonha de ter um filho criminoso".

${ }^{57}$ Respectivamente, Art. 118 e Inciso I do Art. 119 do Estatuto da Criança e do Adolescente.
} 
programas de assistência social parece indicar que a promoção social é entendida como a adoção de políticas compensatórias para o adolescente e sua família. Se for exagerado supor que a liberdade assistida se dirige principalmente aos que necessitam de políticas sociais compensatórias, ou seja, aos segmentos menos favorecidos da população, é importante salientar que, na legislação, existe a propensão de esperar que sejam esses os grupos atendidos.

No entanto, a questão diferencial da liberdade assistida parece ser menos a indicação dos indivíduos para os quais ela se direciona e mais o modo como isso é feito. Assim, a promoção social vai além do adolescente autor de ato infracional sobre o qual se aplica a medida e engloba sua família, apontando que, de algum modo, a situação de risco social e pessoal vivida pelo autor de ato infracional é entendida como uma questão familiar. Por conseguinte, se o Estatuto iguala a família à sociedade e ao Estado como instância que deve garantir os direitos fundamentais do adolescente, ele não parece distribuir igualmente a responsabilidade entre as três instâncias quando esses direitos se encontram ameaçados e levam o adolescente da situação de risco ao ato infracional.

Para além da discussão sobre a situação de risco como causa do fenômeno da criminalidade, a família é convocada a participar do processo socioeducativo de forma desigual em comparação à sociedade e ao Estado. Implicitamente responsabilizada pela situação vivida pelo adolescente, sua entrada nesse processo faz com que ela ocupe posição estrategicamente inferior de objeto de intervenção da ação socioeducativa do Estado e da sociedade, na forma de entidades civis a ele conveniadas e por ele supervisionadas. Como se trata de uma liberdade "assistida", a intervenção envolve vigilância e controle discretos da vida e do convívio familiares que se legitima pela suposta necessidade de que sejam orientados e promovidos.

No entanto, não parece ser esse o caso da medida de semiliberdade, mais severa que a liberdade assistida. A semiliberdade leva o adolescente a pernoitar em uma unidade estatal e permite que ele passe o dia fora, desde que 
cumpra as atividades obrigatórias de escolarização e profissionalização. ${ }^{58}$ A família não é mencionada e não há prescrição sobre intervenções nessa medida, embora implique uma discreta substituição do convívio familiar pelo convívio entre adolescentes. No município de São Paulo, essa substituição pode estar indiciada nos nomes de parte das unidades de semiliberdade, que são chamadas de "casas comunitárias" (ver quadro 1).

Por fim, a internação, a medida mais severa do Estatuto por envolver a privação de liberdade, consiste na inserção do adolescente em uma unidade estatal na qual ele deve permanecer em tempo integral, só podendo sair mediante autorização judicial. A substituição do convívio familiar pela situação de internação é abrupta e a intervenção na vida familiar tende a ser direta, constante e visível. Nesse sentido, as obrigações das entidades que desenvolvem programas de internação são diligenciar no sentido do restabelecimento e da preservação dos vínculos familiares, comunicar à autoridade judiciária, periodicamente, os casos em que se mostre inviável ou impossível o reatamento dos vínculos familiares, proceder a estudo social e pessoal e reavaliar periodicamente cada caso, dando ciência dos resultados à autoridade judicial. ${ }^{59}$

Tendo em vista que a internação rompe abruptamente o convívio familiar, o reatamento e a preservação dos laços familiares podem ser interpretados como o restabelecimento do contato perdido no momento da internação entre o adolescente e sua família de origem. Podem também ter um sentido mais terapêutico-pedagógico, que pressupõe um afrouxamento dos vínculos familiares durante a situação de risco vivida pelo adolescente, levando-o ao ato infracional e à internação. Assim, seria necessário que os funcionários das unidades de internação buscassem fortalecer esses vínculos, estudando-os, descobrindo seus pontos fracos, analisando aqueles acontecimentos que poderiam ter levado à desestruturação da vida familiar.

\footnotetext{
${ }^{58}$ Parágrafo $1^{\circ}$ do Art. 120 do Estatuto da Criança e do Adolescente.

59 Incisos V, VI, XIII e XIV do Art. 94 do Estatuto da Criança e do Adolescente.
} 
Esse segundo sentido aproxima-se da forma como a família é convocada a participar do processo socioeducativo da liberdade assistida. Por conseguinte, também na internação, a família parece ser implicitamente responsabilizada pela situação de risco que leva o adolescente ao ato infracional e torna-se alvo direto e obrigatório do tratamento e da pedagogia socioeducativos.

Em suma, as medidas socioeducativas de liberdade assistida e internação definem-se também como medidas de intervenção, controle e avaliação periódica da vida familiar dos adolescentes autores de ato infracional. Fundamentadas em uma doutrina da proteção integral que visa assegurar o desenvolvimento de adolescentes considerados em situação de risco social e pessoal, essas medidas implicam que o tratamento do autor de ato infracional responsabiliza a família tanto pelo risco quanto pela infração, fazendo dela o alvo da pedagogia terapêutica que permeia as entrelinhas do Estatuto. Por conseguinte, a re-educação familiar torna-se parte integrante da socioeducação do adolescente autor de ato infracional, indicando que a situação de risco da pessoa em desenvolvimento não pode ser solucionada sem que se considerem suas relações familiares.

Ao afirmá-las como ponto de intervenção do tratamento dos adolescentes autores de ato infracional, o Estatuto parece indicar novos desdobramentos na história das estratégias de Estado que incidem sobre os segmentos menos favorecidos da população. Como se procurará discutir no próximo capítulo, essas estratégias marcam a constituição de diferentes eixos de individualização pelas vias do Estado e têm como efeito a produção de distinções nas trajetórias dos indivíduos dos segmentos altos, médios e baixos da população.

Assim, a individualização de crianças e adolescentes pobres emerge no início do século XX com a promulgação do Código de Menores, em 1927, e a conseqüente transformação do encarceramento em instituições estatais na estratégia geral de construção da individualidade dessas crianças e adolescentes como menores. Essa estratégia pautava-se por uma visão que associava o fracasso educativo da família, a pobreza e a marginalidade social como produtoras do 
abandono e da criminalidade. O tratamento dessas questões dava-se pela internação em instituições de Estado que assumiam a responsabilidade pela educação, em substituição aos cuidados familiares considerados “inaptos”.

Se, por um lado, o Estatuto aponta um deslocamento da substituição dos cuidados familiares para seu tratamento terapêutico e a afirmação de sua centralidade no processo socioeducativo, ele instiga, por outro, a questionar a possibilidade de que a família se torne, de fato, uma instituição re-educadora. Nesse sentido, a literatura sociológica a ser abordada no terceiro capítulo desta dissertação parece indicar que, no contexto contemporâneo, a família detém cada vez menos controle sobre o processo educativo, lançando novos desafios à afirmação da família como instituição socioeducadora.

Entendendo a socialização como um processo complexo, que envolve a atuação de diferentes instituições sociais e que busca inculcar nos indivíduos o conjunto de regras necessárias para que possam viver juntos, as diferentes perspectivas sociológicas a serem apresentadas tendem a polemizar a possibilidade da família ser, na modernidade e na contemporaneidade, uma instituição fundamental aos processos de socialização e individualização. Nesse sentido, se a modernidade implicou a retirada da produção material do espaço familiar, com a autonomização da esfera do trabalho e a conseqüente expansão da escolarização como forma de formar os indivíduos para o trabalho, essa restrição do controle familiar sobre o processo produtivo tornou-se o foco da polêmica sobre a possibilidade da família manter sua centralidade socializadora e individualizadora em uma sociedade cuja construção de identidades padronizadas direciona-se para o trabalho. A questão torna-se mais complexa à medida que a família se desinstitucionaliza, ou seja, transforma-se em uma constelação de diferentes significados possíveis. Além disso, as identidades sociais também apresentam tendências "desinstitucionalizadas", isto é, tornam-se cada vez mais flexíveis, mutáveis e despadronizadas.

A saída dessa polêmica foi, aqui, isolar o ponto comum aos diferentes posicionamentos, a saber, a de que as famílias se caracterizam, desde a 
modernidade, pela interferência externa de outras instituições sociais. Assim, optouse por não discutir se, na atualidade, a família é ou não uma instituição socializadora e individualizadora relevante, mas como a possibilidade de que ela o seja faz dela um objeto permanente de interferência e controle social.

Desse modo, procurou-se fazer, no segundo capítulo, uma reconstrução histórica e institucional da relação entre família e Estado, visando traçar as mudanças e os eventuais deslocamentos que ela sofreu a partir da constituição de um eixo socializador e individualizador voltado para crianças e adolescentes pobres que se envolvem com atos ilícitos. Com a reconstrução histórica, buscou-se, então, abordar como as propostas do Estatuto da Criança e do Adolescente podem ser entendidas, na reflexão sociológica, a partir da dinâmica entre a família e outras instituições que buscam nela interferir. 


\section{Capítulo II}

\section{A TRAJETÓRIA DA FAMÍLIA NA INTERNAÇÃO DO ADOLESCENTE}

Uma história de internações para crianças e jovens provenientes das classes sociais mais baixas, caracterizados como abandonados e delinqüentes pelo saber filantrópico privado e governamental elaborado, entre outros, por médicos, juízes, promotores, advogados, psicólogos, padres, pastores, assistentes sociais, sociólogos e economistas -, deve ser anotada como parte da história da caridade com os pobres e a intenção de integrá-los à vida normalizada. Mas também deve ser registrada como componente da história contemporânea da crueldade.

Edson Passetti. ${ }^{60}$

O Estatuto da Criança e do Adolescente, ao salientar as concepções de sujeitos de direitos, pessoas em desenvolvimento e destinatários de absoluta precedência pela família, pela sociedade e pelo Estado como a base de estruturação do atendimento a adolescentes que se envolvem com atos ilícitos, possibilita mudanças na forma como esses têm sido tratados por instituições como a FebemSP. De imediato, indica um investimento na afirmação da adolescência como uma etapa peculiar da formação do ser humano, em que a vulnerabilidade e a fragilidade demandariam cuidados específicos das diferentes instituições responsáveis pelos processos de socialização e também de ressocialização.

Nesse sentido, a família, a sociedade e o Estado seriam convocados a participar conjuntamente desses processos com o intuito de criar um círculo de proteção integral em que a vivência de situações limítrofes ou de risco por pessoas em desenvolvimento seria evitada ou minimizada, diminuindo as possibilidades de inserção ou retorno à criminalidade. No que se refere à punição e ao tratamento daqueles que cometeram atos infracionais, a participação conjunta de diferentes instituições e grupos sociais poderia resultar na diminuição do controle da ressocialização por parte de representantes e instituições de Estado.

\footnotetext{
${ }^{60}$ Passetti, 1999b:350.
} 
Essa diminuição produziria, por sua vez, mudanças na estratégia de encarceramento em instituições de Estado como modelo geral de ressocialização, no qual o tratamento e a recuperação das condutas desviantes ocorreriam por meio da interrupção e do cerceamento do contato com diferentes tipos de agentes e instituições socializadores e sua substituição por um único tipo, focalizado na vigilância e na padronização individuais. Desse modo, a estratégia de encarceramento implica a concentração do investimento ressocializador em uma única instituição e seus agentes, cujo efeito tende a ser, tanto para a trajetória individual quanto para a histórica, a construção de individualidades assujeitadas pelos mecanismos e procedimentos institucionais.

Por um lado, o modelo da ressocialização pelo encarceramento parece estar relacionado a uma concepção moderna de indivíduo na qual sua identidade não é um dado a priori, mas algo que pode ser construído, desconstruído e reconstruído no embate entre instituições sociais e as tendências e opções individuais. ${ }^{61}$ Nesse sentido, as biografias individuais não teriam um percurso totalmente pré-determinado desde o nascimento, mas resultariam das escolhas feitas a partir das possibilidades institucionalmente oferecidas ao longo do processo de socialização. A tarefa da ressocialização seria, portanto, de "disciplinar" essas escolhas, isto é, tornar a identidade e a biografia individuais calculáveis e manipuláveis no sentido de sua adequação a padrões normais.

Por outro lado, ele envolveria uma peculiaridade nessa concepção, qual seja, a de que o envolvimento de adolescentes com atos ilícitos não estaria somente relacionado à escolha ou aptidão individual pelo desvio, mas seria também o sintoma do fracasso das instituições socializadoras em direcionar suas trajetórias para caminhos lícitos. A atribuição da responsabilidade institucional pelo fracasso,

\footnotetext{
${ }^{61}$ Uma interessante abordagem teórica sobre a relação entre modernidade e individualização pode ser encontrada em Zygmunt Bauman (2002), segundo o qual elas seriam uma mesma condição social, no sentido de implicar a transformação da identidade humana de uma dádiva em uma tarefa, ou seja, a substituição da determinação pelo status social pela autodeterminação e pela necessidade de se tornar o que se é. Não obstante a relevância dessa abordagem, a discussão histórica sobre a estratégia de encarceramento como forma de produção de individualidades assujeitadas busca aproximar-se da contribuição teórica de Michel Foucault (1999a), que será desenvolvida no próximo capítulo.
} 
porém, tenderia a pesar mais especificamente sobre uma dessas instituições, a família.

Aparentemente, para o modelo de ressocialização dos adolescentes pelo encarceramento, a família seria considerada o ponto privilegiado de interseção entre socialização e individualização e, por isso, responsável direta pela construção de biografias normais e/ou desviantes. Assim, caberia a ela estabelecer o contato e os vínculos entre as gerações mais novas e as outras instituições socializadoras, como a escola, e garantir que seu desenvolvimento levasse à inserção no mundo do trabalho. Em contrapartida, o desvio individual em relação ao mundo do trabalho, o direcionamento a seu oposto, o mundo da criminalidade, seria o resultado da inaptidão familiar.

No limite, a adoção desse modelo como estratégia de Estado parece implicar a substituição dos cuidados familiares, considerados fracassados ou inaptos, pelos oferecidos em instituições de Estado, que assumiriam as tarefas de socializar e individualizar. Este capítulo propõe, então, fazer um balanço histórico dessa relação entre a estratégia de encarceramento e as famílias das camadas menos favorecidas, para as quais tal estratégia teria se direcionado. Para tanto, toma como base dois acontecimentos ocorridos na trajetória de internação de crianças e adolescentes menos favorecidos ao longo do século XX.

Primeiro, destaca-se a emergência do Código de Menores, de 1927, e a instauração de um campo de discursos e práticas que transformaram a infância e a adolescência pobres em alvos da interferência ressocializadora do Estado. Segundo, salienta-se a criação da Funabem e seu giro "biopsicossocial", um marco na extensão das formas de controle institucionalizado em direção às famílias dos adolescentes autores de ato infracional. O ponto de partida, porém, encontra-se no período histórico que antecede o Código de Menores e que marca o surgimento da concepção moderna de indivíduo na sociedade brasileira, bem como estabelece ruptura e diferenciação entre os processos de socialização e individualização relativos aos filhos da elite e aos filhos das camadas menos favorecidas. 


\section{Instituições "indisciplinadas": as famílias coloniais e a Roda dos Expostos}

Durante muito tempo, defendeu-se que a família patriarcal brasileira teria sido a forma predominante de organização da vida social no período colonial, compreendido entre o século XVI e o início do século XIX. ${ }^{62}$ Nesse sentido, a sociedade colonial poderia ser considerada como "doméstica", pois as famílias concentravam as funções política e econômica, tornando-se, assim, instituições hegemônicas nos processos de socialização e inserção social. ${ }^{63}$

Segundo Antonio Candido de Mello e Souza (1951), a família patriarcal organizava-se hierarquicamente a partir de um núcleo central de poder, constituído de acordo com uma lógica de solidariedade entre parentes, isto é, de uma lógica que vinculava os laços sociais aos laços de sangue. Assim, faziam parte do núcleo o patriarca, sua esposa branca, seus filhos legítimos e outros membros a eles relacionados, de modo geral, pela consangüinidade. Em torno do núcleo, formava-se uma periferia de agregados e escravos, dentre os quais estavam as concubinas do patriarca e seus filhos ilegítimos.

Essas relações extraconjugais com membros da periferia, consentidas ou não, apontavam a satisfação afetivo-sexual como uma questão secundária para o núcleo, cujas prioridades eram a preservação do status político-social e do patrimônio. Os casamentos da elite colonial não resultavam das escolhas afetivas dos noivos, mas de acordos firmados conforme os interesses do grupo familiar. Desse modo, a união conjugal poderia servir tanto para reafirmar a solidariedade

${ }^{62} \mathrm{O}$ conceito de família patriarcal brasileira como tipo de organização familiar predominante no período colonial difundiu-se na primeira metade do século XX, por meio das obras de Gilberto Freyre (1996[1933]), Casa grande \& senzala, e Antonio Cândido de Mello e Souza (1951), The Brazilian family. Contudo, no final do século XX, novos estudos vieram a questionar a predominância da família patriarcal, apontando a ausência de regularidades nas formas de organização familiar que coexistiram durante o período colonial. Nesse sentido, destacam-se o artigo de Mariza Corrêa (1981), Repensando a família patriarcal brasileira, e os ensaios mais recentes de Paulo César Garcez Marins (2002), Mulheres de elite, filhos naturais - São Paulo, séculos XVIII e XIX, e de Helena Maffei Cruz (2002), Segredos, silenciamentos e apagamentos: família - mitos e conceitos.

${ }^{63} \mathrm{Em}$ seus estudos sobre a família, Émile Durkheim define a sociedade doméstica como aquela baseada no comunismo familiar, isto é, na família como um todo cujas partes não teriam individualidade distinta. Para o autor, a família patriarcal poderia ser uma transformação nesse comunismo, pois a situação predominante do pai transferia para sua figura o substrato da vida social antes concentrado na família. Ver Durkheim, 1975b. 
entre os membros do núcleo, havendo freqüentemente casamentos entre parentes (primos ou tios e sobrinhos), quanto para ampliar o poder de uma família por intermédio de sua aliança com outra.

A coesão interna do núcleo familiar em torno da preservação do status político-social e do patrimônio era mantida pela centralização de poder na figura paterna. O pai, chefe do grupo que se estendia do núcleo para a periferia, possuía autoridade praticamente irrestrita, garantindo sua liderança pela força e pelo prestígio econômico.

A submissão a ele e às demandas do grupo familiar pautava-se pela necessidade de organização em um imenso território no qual a existência fora do âmbito doméstico era extremamente difícil. Isso porque a produção material essencialmente agrária exigia investimentos em larga escala e, assim, se concentrava nos latifúndios das famílias patriarcais. Ademais, na ausência de um Estado nacional, as funções de regulamentação e defesa (armada) da ordem social estavam a cargo destas. Enfim, para além das fronteiras da ordem social patriarcal, estavam os socialmente degradados, isto é, uma massa que se reproduzia a esmo e vivia sem normas regulares de conduta. ${ }^{64}$

A partir do século XIX, essa ordem entraria em declínio, juntamente com o fim do período colonial e a modernização da sociedade brasileira. A chegada da corte portuguesa ao Brasil e a abertura dos portos, em 1808, marcaram o início de transformações que enriqueceram a vida social e criaram novas possibilidades de produção econômica e organização política. Primeiramente, os processos de urbanização, industrialização e proletarização modificaram essa sociedade que, até então, era agrária e economicamente voltada para a produção dos latifúndios por meio da utilização de mão-de-obra escrava. Em segundo lugar, com a formação do Estado nacional, a organização política deixaria de ser caracterizada pela diluição do poder em pequenos focos privados, familiares e patriarcais, e passaria à sua centralização em uma ordem pública.

\footnotetext{
${ }^{64}$ No original: The nonfamilial portion consisted of a nameless mass of the socially degraded, those cast off by the family groups or brought up outside of them. They reproduced themselves haphazardly and lived without regular norms of conduct. (Souza, 1951:304).
} 
Para Antonio Candido de Mello e Souza (1951), essa complexificação crescente da sociedade estaria no centro da evolução da família brasileira, pois significou a restrição de suas funções política e econômica e a concentração em funções mais especificamente familiares, a saber, o cuidado com a infância e a regulamentação das relações afetivas entre homens e mulheres.

Contudo, a passagem da família patriarcal para a família moderna vista nesses termos parece reduzir-se à simplificação e especialização de funções limitando a história das famílias no Brasil a uma perspectiva funcionalista e evolutiva (quase) linear. Assim, não obstante suas contribuições, essa perspectiva apresenta um sério equívoco, qual seja, o de apagar da superfície social as lutas políticas travadas entre aqueles que ocupavam posições estratégicas de poder e os que resistiram a eles.

De fato, estudos históricos mais recentes têm colocado em cheque a noção de uma sociedade colonial homogênea, comandada pelos patriarcas e suas famílias, que seria o pressuposto da perspectiva evolutiva para o surgimento da família nuclear. Primeiramente, esses estudos apontam que outras formas de organização familiar co-existiram com a família patriarcal; dessa forma, negligenciálas significaria apagar da memória a heterogeneidade como um dos traços marcantes da sociedade colonial. Em segundo lugar, questionam a suposta autoridade quase absoluta do patriarca, demonstrando que, mesmo entre os membros da elite, existiam desobediências e resistências às regras de conduta da ordem patriarcal.

Sem a homogeneidade assegurada pelo predomínio da família patriarcal, o declínio da sociedade colonial deixa de ser visto como uma evolução linear rumo a uma sociedade mais complexa. Dessa feita, a modernização do século XIX é complexa menos no sentido de uma expansão de instituições e funções sociais e mais pela emergência de grupos e intenções divergentes e de novas posições estratégicas a serem ocupadas. Assim, a homogeneização, ou melhor, as tentativas de padronização eficiente da vida familiar foram o traço marcante que se 
manifestou a partir do século XIX, em que se procurou regulamentar as desobediências, reduzindo-as a um número calculável, observável e controlável.

Ao analisar essas tentativas de padronização do século XIX, Jurandir Freire Costa (1999) assinala a mudança de foco para a infância como uma reconfiguração de poder entre o patriarca, representante da família, e o Estado. Nesse sentido, a ação dos médicos higienistas e suas campanhas sanitárias do século XIX teriam constituído as táticas locais que destituíam o poder do patriarca em nome da proteção da criança (e, posteriormente, do adolescente) e que foram incorporadas pela estratégia de Estado. Contudo, se a análise de Costa explicita os conflitos e rearranjos de poder, ela tem como ponto fraco o pressuposto da hegemonia da família patriarcal. Nesse sentido, o que restava para além desta era a camada dos sem-família, que estava entregue à polícia, ao recrutamento militar ou aos espaços de segregação higienizados como prisões e asilos. ${ }^{65}$

Historicamente, o pressuposto da hegemonia da família patriarcal não se sustenta, sendo mais um efeito das idéias de higienização e homogeneização do século XIX, que procuraram apagar da história social "dizível" os desvios, as irregularidades e as resistências em relação ao primado do patriarca. Como aponta Mariza Corrêa (1981), a alta mobilidade populacional no imenso território a ser colonizado corrói a noção de uma sociedade colonial pasteurizada por núcleos familiares da elite patriarcal e seus agregados submissos. Assim, se o controle externo da Coroa Portuguesa e da Igreja Católica encontrava resistências por parte dos que aqui se fixavam, o controle interno dos patriarcas não era menos contestado. Isto significa que a sociedade colonial era mais multifacetada, móvel, flexível, dispersa e complexa do que é mostrado pelas posteriores tentativas de homogeneizá-la entre famílias patriarcais e "degradados". Desse modo, a história das famílias brasileiras não se reduz a um estudo da forma de organização familiar do grupo dominante, ou de um grupo dominante em uma determinada época e lugar. 66

\footnotetext{
${ }^{65}$ Costa, 1999:33.

${ }^{66}$ Corrêa, 1981:7.
} 
Mais ainda, a multiplicidade dos arranjos familiares coloniais não se concentrava nos segmentos menos favorecidos da população, mas abrangia também membros da elite. Nesse sentido, Paulo César Garcez Marins (2002) aponta que, tanto na sociedade paulista colonial quanto na imperial, os concubinatos, os divórcios e a criação de filhos naturais sem casamento ou de filhos ilegítimos não eram ocorrências tão incomuns no cotidiano de homens e mulheres de elite. ${ }^{67}$ Por conseguinte, o escândalo diante dessas ocorrências tornou-se socialmente significativo a partir do modelo de família nuclear e estável, que emergiu no século XIX e esteve profundamente relacionado ao processo de higienização. Em São Paulo, a estratégia adotada para a construção higiênica das genealogias familiares foi a do apagamento dessas ocorrências escandalosas, desses desvios familiares às normas católicas ou aburguesadas.

Portanto, se não é possível dizer que as famílias patriarcais monopolizavam as manifestações de poder no Brasil colônia, isso se deve ao fato de que essas manifestações se encontravam dispersas, difusas e "indisciplinadas" em vários arranjos familiares e comportamentos que escapavam ao controle patriarcal. Com os higienistas, no entanto, tornar-se-ia possível a organização e concentração de poder, a partir da produção de saberes sobre a família e do estabelecimento de padrões de normalidade e desvio em relação à família higiênica. Essa capacidade de reconfiguração do poder e de seu exercício por intermédio da vida familiar teria sido o que garantiu, aos higienistas, sua influência nos assuntos de Estado e a sanitarização do espaço urbano. E é nesse sentido que a tese de Jurandir Freire Costa (1999) permanece relevante, não obstante seu equívoco em partir do pressuposto de hegemonia da família patriarcal.

Para o autor, o problema que se colocava na formação do Estado Nacional, no século XIX, referia-se a como garantir que a instauração do novo regime político, o Império, não acarretasse insurreições armadas e a exacerbação de dispersões de poder. As estratégias do Império intencionavam uma concentração

\footnotetext{
${ }^{67}$ Cabe ressaltar, desse modo, que o papel feminino na administração das famílias, nas redes de sociabilidade e no comércio informal da capital paulista nos séculos XVIII e XIX dava às mulheres uma relevância social maior do que o mero casamento com um patriarca. Ver Marins, 2002.
} 
política que a Colônia não havia experimentado, visavam à conversão dos membros da elite agrária, de possíveis opositores em aliados da nova ordem. Nesse sentido, a medicina higiênica aparecia como um conjunto de táticas capaz de responder aos anseios das estratégias de Estado, pois os higienistas, servindo de mediadores e intérpretes dos interesses do Estado pela saúde da população, diluíam os antagonismos entre ele e as famílias da elite. ${ }^{68}$

A entrada da medicina higiênica na vida familiar da antiga elite agrária deu-se em nome da conservação e da educação das crianças. Sob a influência do tema da preservação da infância, os higienistas interessavam-se pela criança de elite como objeto de produção do adulto saudável. Desse modo, preocupavam-se com os altos índices de mortalidade infantil, que, a seu ver, refletiam o estado de afrouxamento dos vínculos entre pais e filhos. Esse estado de afrouxamento tinha como fonte a escravidão, isto é, a presença de escravos dentro da casa, espaço da intimidade familiar, e o uso de escravas como babás e amas-de-leite eram tidos, pelos higienistas, como a origem da degradação dos costumes familiares da elite e, por conseguinte, da degeneração e morte de sua prole.

A bandeira da luta higienista pela produção do indivíduo saudável era, então, o estreitamento das relações afetivas entre pais e filhos como forma de assegurar a sobrevivência dos últimos. Assim, surgiram as críticas à Roda dos Expostos e as campanhas de amamentação, que procuravam abolir o uso das amas-de-leite. $^{69}$ A Roda, instituição herdada da Colônia, era acusada pelos higienistas de contribuir para a irresponsabilidade dos pais com os filhos legítimos,

\footnotetext{
${ }^{68}$ Nas palavras de Jurandir Freire Costa (1999:210), a ação patriótica da higiene não era uma cópiacarbono da política. (...) A ciência fazia parte da política. Era um de seus momentos. Uma de suas estratégias específicas. Os médicos, conscientemente, punham à disposição dos governos o que sabiam ou podiam fazer para levarem os indivíduos a compactuarem com a ordem estatal.

${ }^{69}$ Criada no início do século XVIII, a Roda dos Expostos, ou simplesmente Roda, tinha como objetivo acolher as crianças abandonadas. O nome Roda referia-se à forma de recebimento dessas crianças a instalação de um cilindro de madeira que, girando em torno de um eixo e tendo uma parte da superfície lateral aberta, permitia que as crianças fossem entregues a qualquer momento, sem que a pessoa que a deixasse tivesse qualquer contato com os funcionários da instituição. Assim, a Roda servia como um mecanismo de "gestão das irregularidades" da vida familiar colonial, pois se mantinha em sigilo a proveniência dos filhos ilegítimos, muitas vezes filhos dos patriarcas coloniais com suas escravas, mas também filhos de mulheres de elite que queriam esconder ou regularizar pela adoção a existência de filhos sem ou fora do casamento. Ademais, era usada por mulheres das camadas menos favorecidas que se tornavam amas-de-leite nas casas de elite. Ver Costa, 1999:164; Bacellar, 2002.
} 
que eram entregues aos cuidados das inaptas amas-de-leite. Muitas delas abandonavam seus bebês para servirem nas casas de elite, prejudicando a amamentação pela própria mãe. Além disso, a Roda incentivava as ilegalidades familiares, por recolher os filhos ilegítimos sem identificar quem os abandonava.

Ao estreitar os laços entre pais e filhos de elite, a medicina higiênica não gerou somente uma valorização do indivíduo e de seu histórico físico, mas também estimulou o interesse por sua trajetória emocional. Passando da saúde do corpo para a saúde da alma, tomava de assalto o monopólio da Igreja sobre os assuntos da interioridade humana, investia sobre os aspectos de foro íntimo e transformava a dicotomia religiosa entre o bem e o mal em um caleidoscópio de infinitos mistérios, anseios indizíveis, reminiscências e também de paixões desordenadas, perversidades e monstruosidades. ${ }^{70} \mathrm{Em}$ uma palavra, à alma higiênica não bastava a predestinação divina entre a graça e o pecado, pois o que estava em jogo era o percurso pelo qual se construía a saúde e a doença. ${ }^{71}$

Nesse movimento rumo à saúde da alma, a medicina higiênica despertava nas famílias um interesse até então inexistente pelo psiquismo e pelo intimismo de seus filhos. Inundadas pelos conselhos médicos, tornavam-se atentas observadoras do desenvolvimento emocional das crianças, ao mesmo tempo que buscavam adequar-se às prescrições da boa educação higiênica. Assim, questões como amamentação, alimentação, vestuário, exercícios físicos e também demonstrações de amor materno e paterno passavam a ser cuidados familiares essenciais na formação do adulto saudável.

Juntamente com a demanda por cuidados familiares atentos, despertos e discretamente vigilantes, instaurava-se um sistema de interpretação da conduta humana no qual as aspirações, comportamentos, adaptações e desvios seriam

\footnotetext{
${ }^{70}$ Costa, 1999:146.

${ }^{71}$ Apontado por Jurandir Freire Costa (1999), o avanço da medicina em direção ao psiquismo, associado ao declínio da importância religiosa, é observado em diferentes autores que abordaram a emergência histórica da medicina (e, posteriormente, da psiquiatria e da psicanálise) nas sociedades modernas. Esse movimento do confessionário para o consultório pode ser verificado, principalmente, nas obras de Michel Foucault (1999b) e de Christopher Lasch (1991).
} 
determinados pelo indivíduo e sua história. ${ }^{72}$ Dessa forma, a causalidade interna, as particularidades e especificidades da biografia individual, principalmente a infância e a ação educativa da família, transformaram-se no princípio explicativo das condutas e ações individuais. Surgia, portanto, uma concepção de individualidade relacionada à família, em que seus sucessos e fracassos na educação infantil eram vistos como a chave interpretativa das qualidades e deficiências do adulto. No limite, essa concepção implicava a emergência de indivíduos analisáveis e calculáveis, que se tornariam os futuros adultos saudáveis a partir de sua socialização na família higiênica, a "célula-mater" da sociedade.

\section{O destino dos "sem-família": da filantropia religiosa ao problema de Estado.}

Se a individualização dos filhos da elite pode ser pensada, como propõe Jurandir Freire Costa (1999), a partir da ação dos higienistas no século XIX, algo diferente parece ter ocorrido com os filhos dos menos favorecidos. Nesse sentido, seria pertinente pensar não em um processo, mas na constituição de diferentes processos de individualização e socialização que, a partir da modernização da sociedade brasileira, focalizaram igualmente a infância enquanto objeto da produção de saberes e, no entanto, o fizeram de diferentes perspectivas.

Haveria, assim, processos de individualização e socialização que estiveram relacionados à emergência da criança de elite por meio de sua transformação em objeto dos saberes higienistas. Ao problematizar os altos índices de mortalidade infantil, esses saberes não tiveram somente como efeito a individualização da infância, mas também o reordenamento do âmbito privado ao qual ela se destinaria. Dessa feita, a produção da criança saudável significou uma conversão higiênica do espaço familiar e de seus membros no sentido de se tornarem instituição e agentes socializadores voltados para essa produção.

\footnotetext{
${ }^{72}$ Costa, 1999:145.
} 
Em contrapartida, a emergência da criança menos favorecida parece ter se referido a um reordenamento dos espaços públicos a serem ocupados por ela. Embora essas crianças também se deparassem com elevados índices de mortalidade, os saberes produzidos sobre elas privilegiaram problemas outros que não a saúde ou a higiene. Focalizando o abandono e a "vadiagem", isto é, as crianças e os adolescentes que perambulavam "sem-família" pelas ruas da cidade, os saberes sobre a infância pobre no início do século XX relacionavam-se ao problema da manutenção da ordem urbana e tiveram como efeito a conversão jurídico-estatal dos espaços de assistência e dos agentes que, doravante, passariam a atuar na produção do menor.

Nesse sentido, as estratégias de Estado parecem ter se dirigido de maneiras distintas com relação às famílias de um e outro segmento social. Segundo a análise de Jurandir Freire Costa (1999), a estratégia para as famílias de elite visava sua adesão à ordem estatal por intermédio da gestão das questões de higiene de seus filhos. A literatura sobre a infância menos favorecida, por sua vez, desenha uma estratégia de confronto e contraposição às famílias menos favorecidas e seu potencial de desordem, apontando para uma tendência de substituição da vida familiar pela internação em instituições públicas assistenciais e/ou punitivas.

Tudo leva a crer que esse movimento de encarceramento de crianças e adolescentes menos favorecidos, no sentido de sua internação em espaços cercados que mesclavam assistencialismo, violência punitiva e disciplinamento das condutas, teve como ponto de partida o início do século XX. Trata-se do momento em que a infância menos favorecida emergiu enquanto problema social, tornando-se objeto da produção intensa de discursos e práticas que culminariam na promulgação do primeiro Código de Menores, de 1927, e na estatização das instituições de assistência, e que refletiam a forma como o processo econômico e social daquele período seria colonizado pela ideologia da preservação da ordem social. ${ }^{73}$

\footnotetext{
${ }^{73}$ Entre as obras que apontam o final do século XIX e o início do século XX como o momento em que a infância pobre emergiu como questão social, destaca-se o artigo Infância e sociedade no Brasil: uma análise da literatura, de Maria Rosilene Barbosa Alvin e Licia do Prado Valladares (1988). Nele, é apresentada uma revisão exaustiva e minuciosa da produção bibliográfica nacional sobre a infância desde o surgimento dessa questão, no final do século XIX, até a década de 1980. Vale ressaltar,
} 
A passagem para o século $X X$ caracterizou-se por instabilidades e incertezas políticas e econômicas advindas, principalmente, do fim do Império e da abolição da escravidão. ${ }^{74}$ Visando minimizar essas instabilidades e incertezas, um dos problemas cruciais para a recém-proclamada República da "ordem" e do "progresso" era a constituição do trabalhador assalariado, em uma sociedade que ingressara tardiamente no processo de modernização da produção e que havia contado, até então, com a mão-de-obra escrava. Assim, a implantação do novo regime foi marcada pela intenção de modernizar econômica e politicamente o país e, ao mesmo tempo, de garantir que os novos rumos não significassem alterações profundas na estrutura social, ou seja, não trouxessem a desordem ou a revolução. ${ }^{75}$

A modernização tardia significou, por um lado, uma profunda aceleração dos processos de industrialização e urbanização. Seguindo o ritmo de crescimento industrial, a cidade de São Paulo passaria de 30 mil habitantes, em 1870, para 286 mil, em 1907 - um crescimento demográfico de quase dez vezes em um período de 37 anos. Por outro lado, a industrialização e a urbanização foram acompanhadas de uma profunda deterioração das condições sociais, habitacionais e de saneamento das camadas menos favorecidas. ${ }^{76}$ As fábricas para onde essas camadas se encaminhavam eram, em muitos casos, espaços insalubres e de instalações precárias. Sua arquitetura de pouca iluminação e baixa circulação de ar, aliada ao ruído das máquinas, à grande quantidade de operários ali amontoados e

como publicações mais recentes que versam sobre esse tema, os artigos de Edson Passetti (1999b), Crianças carentes e políticas públicas; e de Marco Antonio Cabral dos Santos (1999), Criança e criminalidade no início do século. Sobre as propostos do primeiro Código de Menores, destaca-se a dissertação de Marcos Cézar Alvarez (1989), A emergência do Código de Menores de 1927: uma análise do discurso jurídico e institucional da assistência e proteção aos menores.

${ }^{74}$ Embora não seja uma referência bibliográfica acadêmica, o romance Esaú e Jacó, de Machado de Assis (1996), fornece um interessante retrato do período de transição entre o Império e a República.

75 Segundo Florestan Fernandes (1975:19), a desaprovação do escravismo e a defesa do abolicionismo transformaram-se em uma revolução social dos "brancos" e para os "brancos": combatia-se (...) não a escravidão em si mesma, porém o que ela representava como anomalia, numa sociedade que extinguira o estatuto colonial, pretendia organizar-se como Nação e procurava, por todos os meios, expandir internamente a economia de mercado.

${ }^{76}$ Estima-se que um terço das habitações em São Paulo eram cortiços. Além disso, a ocorrência de pestes e epidemias era comum no período. Sobre os dados de crescimento populacional e habitação em São Paulo, ver Santos, 1999: 212. 
às longas jornadas de trabalho, fazia das fábricas um local propício aos acidentes de trabalho e ao alastramento de doenças, como a tuberculose. ${ }^{77}$

Além dos adultos, muitas crianças e vários adolescentes participavam do e eram vitimados pelo trabalho precário nas fábricas. Com os baixos salários pagos aos homens adultos, a renda familiar era complementada pelo trabalho de mulheres, adolescentes e crianças. Recebendo salários ainda menores para executarem as mesmas funções, crianças e adolescentes eram submetidos a difíceis condições de trabalho e, não raro, sofriam maus tratos de patrões e representantes de chefia. $^{78}$

Com a eclosão dos movimentos operários, liderados principalmente por imigrantes italianos e espanhóis, a denúncia da exploração do trabalho infantojuvenil transformou-se em uma das bandeiras na luta pelos direitos trabalhistas. No entanto, e de imediato, essa e outras reivindicações foram tratadas como caso de polícia. Juntamente com os movimentos operários, a prostituição, a criminalidade e os menores "vadios", crianças e adolescentes que não tinham sido cooptados pelo trabalho nas fábricas e viviam pelas ruas da cidade, transformavam-se em questões de ordem para as quais se disseminariam aparelhos policiais de controle voltados repressão social.

Por conseguinte, o trabalho infanto-juvenil ou a mortalidade infantojuvenil nas fábricas e cortiços ou, ainda, a deterioração das condições de vida das famílias dessas crianças e jovens não constituíram o eixo propulsor daqueles que entrariam para a história como destacados defensores da infância menos favorecida. ${ }^{79}$ Efetivamente, os discursos de proteção e assistência a essa infância,

\footnotetext{
${ }^{77}$ Sobre as condições precárias de vida das camadas menos favorecidas na passagem para o século XX, ver Santos, 1999; Passetti, 1999b; Moura, 1999.

${ }^{78}$ Vale ressaltar que as mulheres também recebiam salários inferiores aos homens para executarem as mesmas funções nas fábricas. Nesse sentido, os movimentos operários do início do século XX colocavam como plataforma de luta pelos direitos dos trabalhadores tanto a proibição do trabalho infantil quanto a equalização da remuneração entre o trabalho realizado por homens e por mulheres. Ver Moura, 1999:262, Passetti, 1999b:350-2.

${ }^{79}$ Segundo Marcos Cézar Alvarez (1989), entre o final do século XIX e o início do século XX, constituiu-se um movimento a favor da infância abandonada e delinqüente no Rio de Janeiro e em São Paulo. Destacaram-se como defensores de uma nova concepção de justiça para a infância e adolescência Tobias Barreto, Evaristo de Moraes e Ataulpho de Paiva, cujas obras defendiam mudanças na legislação; Alcindo Guanabara, redator do primeiro projeto legislativo para a
} 
que floresceram na República Velha e culminaram na promulgação do primeiro Código de Menores, priorizavam a dicotomia entre trabalho e vadiagem e negligenciavam os conflitos inerentes ao mundo do trabalho. ${ }^{80}$

Esses discursos não se direcionavam a crianças e adolescentes nas fábricas, mas aos que estavam nas ruas e eram tidos ora como abandonados ora como "vadios" e "delinqüentes". Assim, procuravam identificar e individualizar todo um contingente populacional que, até então, escapara à socialização pelas vias produtivas, isto é, ao trabalho nas fábricas e às escolas. ${ }^{81}$ Desse modo, estabeleciam - como objeto de produção de saberes sobre a infância pobre crianças e adolescentes que, perambulando pelas ruas, estavam fora da produção e, por isso, expostos ao exercício de atividades ilícitas.

Duas concepções configuravam-se como centrais para a escolha desse objeto. A primeira delas era a de que o trabalho - entendido como o exercício de uma atividade remunerada e, principalmente, regular - seria capaz de assegurar a inserção dos pobres no mundo da ordem, afastando-os da ociosidade e da criminalidade a ela relacionada. A segunda era a de que a origem da criminalidade estaria situada na infância, ou seja, o "delinqüente" juvenil tenderia a se tornar o criminoso adulto. ${ }^{82}$

No entanto, o fato dessas crianças e desses adolescentes estarem fora da produção não era visto como algo deliberado. Nesse sentido, uma das operações centrais para os discursos de proteção e assistência à infância menos favorecida era concentrar a responsabilidade pela situação de abandono ou delinqüência de crianças e adolescentes na instituição que primeiro deveria garantir sua inserção nas vias produtivas: a família. A ausência ou a deficiência dos cuidados familiares e a impossibilidade de a família orientar os filhos para o caminho da educação e do

menoridade; e Mello Mattos, responsável pela redação do Código de Menores e primeiro juiz de menores brasileiro. Cabe ainda mencionar o pediatra Moncorvo Filho, defensor do ideário de que a infância moralizada e higiênica era o alicerce da sociedade sadia.

${ }^{80}$ Em sua análise do Código de Menores de 1927, Alvarez (1989:195) assinala a ausência, nessa legislação, de mecanismos concretos que pudessem minimizar a exploração do trabalho infantil e generalizar o acesso à educação.

${ }^{81}$ Cf. Alvarez, 1989.

${ }^{82}$ Ver Santos, 1999:215-22. 
trabalho seriam, então, as causas do abandono material ou moral que levaria crianças e adolescentes a viver pelas ruas.

Tida como resultado do estado de abandono, a delinqüência não teria sua origem na vontade do delinqüente, mas na ação negligente de seus pais. ${ }^{83} \mathrm{~A}$ chave de interpretação das condutas delinqüentes passaria pela reconstrução de trajetórias individuais marcadas pelo abandono material ou moral da família e deixaria de ser, simplesmente, fruto da má índole. Retomava-se, assim, a concepção de individualidade relacionada à família que havia sido adotada pelos higienistas do século XIX e que enfatizava a causalidade interna como princípio interpretativo das condutas individuais. Nessa concepção, os comportamentos, as qualidades, as deficiências e os desvios que caracterizavam o indivíduo eram explicados como resultado de fatores internos à sua história, principalmente sua infância e o desempenho educativo de sua família.

O sistema de interpretação de condutas produzido pelos discursos do início do século XX enfatizava essa causalidade interna, isto é, a dimensão individual das trajetórias de abandonos e delinqüentes, em detrimento das condições socioeconômicas em que se inseriam. Porém, esses discursos também ressignificavam a concepção higienista de individualidade, pois a causalidade interna de seu sistema de interpretação dependia mais da história familiar do que dos indivíduos em questão.

Estabelecido o objeto para o qual os discursos se direcionavam, as crianças e adolescentes que perambulavam pelas ruas, e construída sua chave interpretativa sobre esse objeto, a ausência ou insuficiência dos cuidados familiares, restavam ainda suas propostas para solucionar o problema que se colocavam, qual seja, o do abandono e da delinqüência. Nesse sentido, defendiam uma leitura do problema como sendo social, ou melhor, de Estado. Assim, sua proposta era a substituição dos cuidados familiares, ausentes ou deficientes, pelos cuidados de instituições de assistência que, geridas pelos Estado, seriam capazes de transformar abandonados e delinqüentes em futuros trabalhadores.

\footnotetext{
${ }^{83}$ Ver Alvarez, 1989.
} 
Diferentemente das campanhas higienistas que, em nome da produção do indivíduo saudável, haviam modificado as relações familiares para que garantissem os cuidados à infância, os discursos de proteção e assistência à infância menos favorecida, visando à produção do indivíduo trabalhador, propunham a transformação das instituições de assistência para que estas substituíssem os cuidados familiares. Para tanto, pretendiam re-organizar as instituições já existentes, boa parte das quais privadas ou religiosas, e construir um complexo institucional capaz de absorver tanto abandonados quanto delinqüentes.

A construção desse complexo passava pela centralização das instituições de assistência à infância e adolescência no Estado. Isto porque as propostas desses discursos e, posteriormente, as regulamentações do Código de Menores objetivavam sistematizar os serviços de assistência de maneira eficiente. No entanto, as instituições existentes no início do século $X X$, muitas das quais privadas e religiosas, atuavam de forma irregular, esparsa, desorganizada e não conseguiam absorver todo o contingente de crianças e adolescentes que seria abrangido por sua atuação.

Dentre as instituições da época, havia a Roda dos Expostos. ${ }^{84} \mathrm{Se}$, para os higienistas do século XIX, esta representava riscos à saúde das crianças de elite, as questões que a levaram a ser novamente criticada no início do século XX eram de outra ordem. ${ }^{85}$ Destinada ao acolhimento de crianças abandonadas e operando na lógica da caridade religiosa, a Roda era vista como um grande depósito de expostos, pouco tendo a oferecer para a produção do indivíduo trabalhador. Assim, para os discursos de proteção e assistência à infância menos favorecida, ela estava longe de ser uma instituição eficiente.

Havia também as casas de correção, instituições aparentemente públicas herdadas do Império e destinadas ao recolhimento de adolescentes de 14 a

\footnotetext{
${ }^{84}$ Segundo Roberto da Silva (1997), a Roda dos Expostos da cidade de São Paulo, criada no século XVIII, continuaria operante até 1951.

${ }^{85}$ Vale ressaltar que a crítica dos higienistas à Roda relacionava-se ao recurso a amas-de-leite pelas mulheres de elite, pois viam a amamentação como fundamental para o estreitamento dos cuidados com os filhos. Já o abandono de bebês por parte das amas era uma questão secundária. Ver Costa, 1999:164-70.
} 
17 anos envolvidos criminalmente, ou mesmo menores de 14 anos, que tivessem obrado com discernimento. ${ }^{86}$ No entanto, há pouca informação sobre essas casas na literatura revisada, podendo-se apenas supor que também se assemelhassem à noção de depósito, uma vez que haviam sido criadas a partir da concepção punitiva de justiça do Império e não da concepção recuperadora que se difundia no início do século $X X$.

Enfim, havia os institutos privados de recolhimento. Criados por religiosos ou particulares ligados à indústria e ao comércio, esses institutos tinham como diretriz fornecer ensino profissional aos filhos de operários e comerciantes. Por um lado, devido ao ensino profissional, eram as instituições que mais se aproximavam das propostas dos discursos de proteção e assistência à infância menos favorecida. Por outro, contudo, a "clientela" que atendiam era diferente. Os filhos de operários e comerciantes que freqüentavam esses institutos eram parte do contingente populacional que recebia cuidados familiares e estava sendo inserido nas vias produtivas por meio da educação profissional. Já o contingente dos abandonados e delinqüentes era outro, o dos "sem-família", dos que perambulavam pelas ruas e que seriam, posteriormente, "filhos do Estado". ${ }^{87}$

Embora o Estado contasse com algumas vagas nos institutos privados de recolhimento, seus diretores relutavam em aceitar crianças e adolescentes envolvidos judicialmente com crimes. ${ }^{88}$ Assim, mesmo sendo esses institutos o tipo de instituição assistencial capaz de produzir o indivíduo trabalhador, havia uma segmentação, uma diferenciação populacional que dificultava a absorção de abandonados e delinqüentes.

Não obstante, é possível que esses institutos tenham sido modelo para a criação das colônias correcionais e das instituições estatais de assistência que surgiram no início do século XX. Sob a influência da pedagogia do trabalho, essas

\footnotetext{
${ }^{86}$ Nos Códigos Penais do Império e da República, os menores de 14 anos eram passíveis de punição caso tivessem consciência de que o ato cometido era criminoso. Cf. Santos, 1999.

${ }^{87}$ Essa noção de filhos do Estado foi colocada por Roberto da Silva para definir crianças e adolescentes que passaram boa parte de suas trajetórias em instituições estatais de assistência e que tiveram, por isso, sua socialização marcada por esse vínculo. Contudo, o autor adota a expressão filhos do governo. Ver Silva, 1997.

${ }^{88}$ Cf. Santos, 1999:222.
} 
colônias e instituições tinham como objetivo claro e declarado a produção de indivíduos aptos para o trabalho, de indivíduos moralizados e trabalhadores. Em uma palavra, e para citar Michel Foucault (1999a:119), visavam a transformação de crianças e adolescentes que estavam nas ruas das cidades em indivíduos economicamente úteis e politicamente dóceis.

\section{O Instituto Disciplinar e o Código de Menores de 1927.}

A literatura revisada que aborda a infância e a adolescência pobres no Brasil, no início do século $X X$, não permite afirmar em que medida os institutos privados de recolhimento foram um modelo para a criação das colônias correcionais e das instituições de assistência. No entanto, ela assinala o surgimento de um ideário da pedagogia do trabalho como forma de inserir socialmente os que escapavam ao sistema produtivo. ${ }^{89}$ Nesse sentido, emergiam novos modelos de encarceramento de crianças e adolescentes, quase ao mesmo tempo que se organizava uma movimentação discursiva em torno de mudanças sobre a menoridade na legislação. Uma nova concepção de justiça para os menores delinqüentes, justiça essa recuperadora e não mais punitiva, surgia juntamente com novos projetos institucionais que pretendiam regenerar as condutas delinqüentes por meio do trabalho. ${ }^{90}$

Havia, assim, uma dupla movimentação no início do século $X X$. Primeiro, os discursos de proteção à infância menos favorecida, que transformaram abandonados e delinqüentes em objeto da produção de saber, relacionaram sua situação à ausência ou deficiência dos cuidados familiares, propuseram sua substituição pelos cuidados do Estado e defenderam a criação de uma justiça recuperadora para menores. Segundo, as práticas institucionais, que transformaram

\footnotetext{
${ }^{89}$ Cf., principalmente, Alvarez, 1989; Santos, 1999 e Silva, 1997. Ver também Alvim \& Valladares, 1988; Passetti, 1999a:21-52; Passetti, 1999b.

${ }^{90}$ Optou-se por utilizar o termo menor para referir-se a esse período histórico justamente porque nele se deu a emergência da categoria menor. Tal categoria viria a ser questionada somente a partir da década de 1980, com os movimentos de defesa dos direitos civis e a redemocratização do país.
} 
as instituições de assistência (e punição), de depósitos de gente em grandes laboratórios para a regeneração das condutas.

Contudo, antes mesmo da consolidação dos discursos de proteção e assistência à infância menos favorecida no Código de Menores, as práticas institucionais já estavam em andamento. Entre a fundação do Instituto Disciplinar de São Paulo, em 1902, e a promulgação do Código, em 1927, transcorreu um período de 25 anos.

Mais uma vez, a literatura revisada não permite afirmar em que medida instituições como o Instituto Disciplinar podem ter influenciado a formulação da legislação que visava à proteção e assistência à infância menos favorecida. Ainda assim, acredita-se que essas novas formas de encarceramento tenham sido relevantes para as mudanças na legislação. Sua relevância reside na possibilidade de que os primeiros laboratórios de regeneração das condutas tenham fornecido a experiência necessária à formulação das propostas dos discursos de proteção e assistência a infância menos favorecida. Tudo leva a crer que as práticas institucionais localizadas, como as colônias correcionais, o Instituto Disciplinar e, até mesmo, os institutos privados de recolhimento, foram incorporadas de algum modo à nova estratégia de encarceramento como forma de ressocialização proposta no Código de Menores.

Essa incorporação pode ser percebida a partir da relação entre a concepção de uma justiça recuperadora, educativa e disciplinar, presente no Código, e as práticas de frentes de trabalho, combate ao ócio, educação cívica e formal do Instituto Disciplinar. Além disso, o Código veio a corrigir uma falha do Instituto; a saber, a forma de recrutamento dos internos, prevista pela legislação, dava margem a pedidos de soltura que escapavam ao controle dos funcionários do Instituto.

O Instituto Disciplinar e a Colônia Correcional de São Paulo foram fundados entre 1902 e 1903, para atender à demanda de criação de instituições públicas de recolhimento dos abandonados e delinqüentes. Nesse sentido, o aumento da criminalidade no início do século levou juristas e autoridades policiais a pressionarem o governo estadual, que encontrava dificuldades em inserir as 
crianças e adolescentes em institutos privados de recolhimento e não tinha uma instituição específica para que eles cumprissem suas sentenças. ${ }^{91}$

Segundo Marco Antonio dos Santos (1999), a Colônia Correcional foi criada com o objetivo de recolher crianças e adolescentes que haviam sido judicialmente condenados. Os internos assim recolhidos eram submetidos aos regimes de enclausuramento e correção das condutas pelo trabalho. Já o Instituto Disciplinar não abrigava somente os condenados por crimes, mas também os abandonados entre 9 e 14 anos, que ficavam separados em outra seção.

Construído no bairro do Belenzinho, o Instituto tinha como práticas iniciais o registro dos internos em livros de matrícula, o interrogatório, o exame médico e o recebimento de um uniforme. Finda uma pequena fase de adaptação, eles eram inseridos nas atividades cotidianas, isto é, nas frentes de trabalho, principalmente agrícola, e nas aulas de ginástica, instrução militar, educação cívica e formal. ${ }^{92}$ Visando combater o ócio, essas atividades limitavam excessivamente os momentos de lazer, que eram quase ausentes. O regimento interno não permitia a comunicação com o mundo exterior, excetuando somente as visitas dos pais e correspondências com eles. Além disso, o Instituto contava com um sistema rígido e gradativo de punições e premiações das condutas, embora não permitisse castigos físicos. $^{93}$ Enfim, o Instituto era quase uma instituição disciplinar, nos termos foucaultianos. ${ }^{94}$

\footnotetext{
${ }^{91}$ Com a promulgação do Código Penal Republicano, em 1890, ficou estabelecida a aplicação de penas de correção para menores em estabelecimentos disciplinares industriais (Santos, 1999:216). Assim, o Código Penal Republicano parece ser uma legislação transitória entre a antiga concepção de justiça punitiva do Código Penal Imperial, pois manteve o dispositivo do discernimento, e a concepção de justiça recuperadora do Código de Menores, com a especificação da punição em estabelecimentos disciplinares industriais e não mais em casas de correção.

${ }^{92}$ Para uma relevante discussão do trabalho como forma de recuperação das condutas, ver Salla, 1991.

${ }^{93}$ As informações sobre o Instituto, apresentadas por Marco Antonio Cabral dos Santos (1999:222-9) a partir de documentos históricos, afirmam a não aplicação de castigos corporais. No entanto, o livro de memórias de Jacob Penteado (2003:66) relata algo diferente: Os meninos do instituto levavam uma vida bem dura. Levantavam às 4 horas da manhã, no verão, e às cinco, no inverno. Após o banho no Tietê, tomavam café e iam, sem mais demora, para o guatambu, cultivar a imensa área, aos dois lados do rio. Devido aos maus tratos dos feitores, que lhes batiam com rabo de tatu, muitos fugiam, uniformizados, buscando refúgio nas casas vizinhas. Quando apanhados, eram açoitados e metidos em banho de salmoura.

${ }^{94}$ Ver Foucault, 1999a:117-142.
} 
As formas de desligamento do Instituto eram a fuga, um recurso freqüentemente usado, a recomendação do diretor, devido à boa conduta, e aplicação do interno, ou o apelo dos pais ao juiz. Essa última forma era também comum, sendo grande a quantidade de pedidos de soltura assim encaminhados. Os pedidos que vinham de apelos dos pais refletiam o modo como as apreensões policiais e o julgamento de seus filhos ocorriam, não raro, sem o seu conhecimento. Visando deter todo e qualquer indivíduo encontrado a pedir esmolas ou que fosse "reconhecidamente" vagabundo, a polícia tinha crianças e adolescentes como alvo privilegiado. ${ }^{95} \mathrm{~A}$ ausência dos pais e a dificuldade em comprovar uma ocupação de trabalho eram, no momento da apreensão, circunstâncias consideradas suficientes para o enquadramento no crime de "vadiagem". ${ }^{96}$

Contudo, ao saberem da apreensão e envio de seus filhos para o Instituto, muitos pais recorriam ao poder judiciário com o intuito de obter sua liberação. Uma das formas de apelo utilizava o dispositivo jurídico do discernimento. Assim, diversas famílias procuravam comprovar a incapacidade mental e conseqüente irresponsabilidade de seus filhos. Como o discernimento para os adolescentes entre 14 e 17 anos era presumido, seus pais eram impelidos a buscar outras formas para fundamentar os pedidos de soltura.

Quando concedidos, esses pedidos enfraqueciam tanto a legitimidade da autoridade policial quanto a capacidade pedagógica do Instituto, pois questionavam os critérios de apreensão, julgamento e tratamento das crianças e dos adolescentes. Por conseguinte, causavam indignação nos diretores do Instituto e em autoridades em geral, que perdiam o controle sobre o tempo de permanência dos internos. Abria-se, assim, um flanco de disputa entre as famílias e autoridades

\footnotetext{
${ }^{95}$ As apreensões policiais de crianças e adolescentes povoavam a imaginação de pais e filhos. Segundo Santos (1999:227), em 1903, inaugurado o instituto, o temor tinha se espalhado pela cidade em virtude do boato de que a polícia andava pelas ruas capturando menores indistintamente para enclausurá-los na instituição. No bairro do Brás, muitos pais teriam tirado seus filhos das escolas, munindo-os de salvo-conduto para evitar tal desgraça. Para Penteado (2003,65-6): Meus tios, para assustar-me, afirmavam que havia, também, 'carrocinha de meninos', que levava os moleques para o Instituto.

${ }^{96}$ Para Marco Antonio Cabral dos Santos (1999), as prisões e apreensões policiais da República Velha caracterizavam-se por uma profunda arbitrariedade. No entanto, a ação da polícia não parece ter sido tão arbitrária, pois, como braço armado da defesa da ordem republicana, a polícia objetivava a apreensão dos elementos considerados "desordeiros" em potencial.
} 
policiais, diretores do Instituto e, até mesmo, juristas, em torno da internação de crianças e adolescentes a fim de regenerar suas condutas. Para aquelas, era crucial demonstrar que a internação havia sido arbitrária e que, por isso, não era necessária sua continuidade. Para esses, era preciso desacreditar as famílias, apontar sua incompetência em educar seus filhos e diminuir sua possibilidade de interferir na internação.

\begin{abstract}
(...) infelizmente as nossas leis dão aos juízes um excessivo arbitrio, e estes, muitas vezes sugestionados pelo empenho dos pais, pelas lágrimas pouco sinceras de mães, que não souberam educar seus filhos, e querem ter criados a sua disposição, pelo falso interesse de protetores da última hora, que só visam o trabalho, ou o pecúlio já acumulado desses infelizes, e que uma vez dissipado este, os lançam em completo abandono, ordenam a sua liberação, sem se aperceberem que, interrompendo a ação do instituto e atendendo a esses pedidos impertinentes, tornam-se os únicos responsáveis pelo insucesso (...) muitas vezes, quando depois de um labutar insano, vai o menor dando esperanças de emenda, surge uma intempestiva ordem de soltura, que vem anular todo o trabalho feito e concorrer para que o menor retorne ao instituto mais endurecido e corrompido do que quando ali entrou pela primeira vez. ${ }^{97}$
\end{abstract}

Na perspectiva dos defensores do Instituto, a internação em instituições de assistência e recuperação seria capaz de transformar as condutas, de evitar que o "menor delinqüente" viesse a ser o criminoso adulto. Acreditava-se que a pedagogia do trabalho e outras práticas disciplinares seriam capazes de operar tal transformação, sendo fundamental que o processo não fosse abruptamente interrompido, mas levado até o fim, isto é, até a recomendação do diretor ao juiz.

Nesse sentido, havia um descompasso entre a defesa do recolhimento e o posicionamento de juízes que, aceitando os pedidos de soltura encaminhados pelos pais, prejudicavam o processo de regeneração das condutas de crianças e adolescentes. No entanto, esse descompasso foi superado pela consolidação da concepção de justiça recuperadora do Código de Menores de 1927. Nela, o juiz especializado de menores tornava-se uma figura paternal, assumindo os cuidados educativos de crianças e adolescentes que, com o fim do dispositivo do discernimento, não poderiam mais ser responsabilizados por seus atos. Agente privilegiado na determinação e manutenção do encarceramento, o novo juiz paternal

\footnotetext{
${ }^{97}$ Motta Apud Santos, 1999:227.
} 
e educador dificilmente cederia aos apelos dos pais contra um tratamento institucional que se colocava como recuperador e racional.

Para Alvarez (1989), a concepção de justiça recuperadora do Código de Menores significou uma perda do pátrio poder, pois restringiu o campo de atuação das famílias. Ademais, ao regulamentar a política de internação, o Código expandiu o campo de ação do Estado e inscreveu crianças e adolescentes no registro da tutela estatal. Assim, as relações entre pais e filhos passaram a ser fiscalizadas pelo Estado, que assumiu a responsabilidade pela educação em substituição à família, quando essa fosse considerada ausente ou incompetente.

\section{Tentativas de centralização dos serviços de assistência: o Serviço de}

\section{Assistência a Menores e o Recolhimento Provisório de Menores.}

Se o Código de Menores foi, como coloca o autor, um instrumento de controle da desordem urbana, pois permitia a identificação e individualização de um contingente populacional que estava fora do sistema produtivo, esse mesmo controle não poderia ser entendido sem as práticas de internação. Ordenar as ruas da cidade era retirar delas essa massa populacional amorfa e recolhê-la em instituições que pudessem identificá-la, estudá-la, conhecê-la e tratá-la.

Tratava-se de uma individualização pelo poder, isto é, da produção de uma espécie de indivíduos descritíveis e calculáveis que, cada vez mais, ficariam conhecidos como menores. Essa individualização passava por um eixo diferente da produção do indivíduo de elite, pois os menores definiam-se por ocuparem posições pouco privilegiadas na sociedade. Assim, nos termos de Alvarez (1989), tratava-se da sujeição de crianças e adolescentes das camadas menos favorecidas e de sua inserção em trajetórias individuais institucionalizadas de antagonismo entre trabalho e delinqüência. ${ }^{98}$

\footnotetext{
${ }^{98}$ A vivência desse antagonismo e seus desdobramentos para a constituição da identidade dos jovens pobres foram brilhantemente tratados no clássico estudo de Alba Zaluar (1994).
} 
Dito de outro modo, na primeira metade do século $X X$, constituíam-se processos diferenciados de socialização e individualização destinados aos jovens das camadas pobres. Por um lado, havia a socialização pelo ingresso precoce no mundo do trabalho, que, afirmando-se pela necessidade de sobrevivência material individual e familiar, tendia a produzir, desde cedo, individualidades trabalhadoras assujeitadas pela disciplina produtiva. Partindo do trabalho infanto-juvenil nas fábricas do início do século, esse eixo socializador pela via produtiva passaria, a partir da década de 1940, a caracterizar-se por um duplo movimento de expansão da escolarização pública e de criação dos cursos privados de aprendizado técnicoprofissionalizante. ${ }^{99}$ Por outro lado, com o Código de Menores, construía-se a possibilidade de socialização pelo ingresso precoce nas instituições públicas punitivo-assistenciais, que produziriam individualidades assujeitadas pela repressão totalizadora das condutas.

Esse segundo eixo socializador envolvia, primeiramente, técnicas de controle policial da circulação de jovens no espaço urbano, que visavam retirá-los da rua e empurrá-los para os espaços institucionais do trabalho, da escola e da família. Em segundo lugar, desenvolvia técnicas de intensificação do controle social sobre aqueles que escapavam a esses espaços por intermédio da internação em instituições de Estado. Para tanto, o eixo socializador pela via do encarceramento transferia o controle sobre a educação e a inserção no mundo do trabalho, da família para o Estado, que assumia a tarefa de re-encaminhar os desviantes para o eixo de socialização produtiva. ${ }^{100}$

Nesse sentido, a sujeição de crianças e adolescentes aos procedimentos totalizadores do encarceramento não pode ser entendida sem as mudanças de configuração das relações entre famílias pobres e Estado. Quando o

\footnotetext{
${ }^{99}$ Cf. Alvim \& Valladares, 1988.

100 A transferência da autoridade familiar dos pobres para o Estado não parece ter sido uma peculiaridade do contexto brasileiro. Nesse sentido, Phillippe Meyer (1975) aponta a ocorrência de um movimento de transferência, na sociedade francesa, a partir da regulamentação e da transferência do controle familiar sobre a correção paterna para o Estado. Assim, a correção, entendida como o encarceramento temporário de jovens em instituições públicas, deixara de ser uma forma usada pelas famílias para lidar com os filhos rebeldes e passara a ser gerida pelos juízes e profissionais sociais que, por meio do inquérito social e do controle do tempo de aprisionamento educativo, produziam instrumentos de penetração e pressão normalizadora do Estado sobre as famílias.
} 
Instituto Disciplinar foi criado, os posicionamentos sobre o encarceramento eram ainda heterogêneos, de modo que os juízes oscilavam entre atender aos pedidos das famílias para que soltassem seus filhos e aos protestos dos defensores da ordem urbana, que queriam assegurar aos funcionários do Instituto o poder de determinar ou não a soltura. Com o Código, no entanto, iniciou-se uma tendência à homogeneização das estratégias de Estado com relação à infância e à adolescência menos favorecidas em prol do encarceramento, colocando o Estado em uma posição hierarquicamente superior, de vigilância, fiscalização e oposição às famílias.

No momento em que a delinqüência deixou de ser um ato e passou a envolver a consciência e os estados de alma do criminoso, quando sua vida pregressa se transformou na chave explicativa para o ato, o fracasso da família na educação dos filhos tornou-se inerente à situação de delinqüência. Assim, a estratégia de encarceramento justificava-se e implementava-se pela substituição dos cuidados familiares pelos institucionais, como forma de garantir a regeneração dos "menores delinqüentes".

Por intermédio das tendências de centralização e sistematização dos serviços de assistência pública e privada pelo Estado, o encarceramento foi se enraizando ao longo do século XX. E, embora, na literatura revisada, haja pouca informação sobre o período decorrido entre a promulgação do Código de 1927 e a criação da Fundação Nacional do Bem-Estar do Menor - FUNABEM, em 1964, é possível detectar o surgimento de algumas tentativas no sentido da centralização e sistematização desses serviços.

Em 1938, surgiu o Serviço Social dos Menores Abandonados e Delinqüentes em São Paulo, visando fiscalizar o funcionamento administrativo e fornecer orientação médico-pedagógica às instituições de amparo e reeducação de crianças e adolescentes, recolher aqueles temporariamente sujeitos à investigação e distribuir os que haviam sido julgados pelos estabelecimentos do Serviço. ${ }^{101}$

Em 1941, no Rio de Janeiro, foi criado o Serviço de Assistência a Menores - SAM, instituição pública cujo objetivo era sistematizar e orientar os

${ }^{101}$ Cf. Passetti, 1999b. 
serviços de assistência a menores "desvalidos" e "delinqüentes" internados em estabelecimentos oficiais e particulares. ${ }^{102}$

Inspirado no SAM, o Recolhimento Provisório de Menores - RPM - foi criado em São Paulo, em 1954. O RPM era uma instituição pública vinculada ao Juizado de Menores que tinha por objetivo fornecer abrigo provisório aos adolescentes acusados de crimes. Nele, instituía-se a perícia técnica como prática privilegiada, de modo que era executado o exame físico, mental e moral dos internos, bem como era avaliada a situação econômica, social e moral de seus pais ou responsáveis. ${ }^{103}$

A partir do Golpe Militar de 1964, o RPM e o SAM seriam substituídos por um amplo e ambicioso projeto de institucionalização do encarceramento, que englobava a Política Nacional do Bem-Estar do Menor - PNBEM - e a Fundação Nacional do Bem-Estar do Menor - Funabem - e deixaria a Fundação Estadual do Bem-Estar do Menor - Febem - como legado para a sociedade redemocratizada.

\section{A internação coroada: os militares e a Fundação Estadual do Bem-Estar do}

\section{Menor.}

Segundo Gutemberg Alexandrino Rodrigues (2001), a Funabem deve ser entendida como a estratégia social dos militares, ou seja, como o veículo disseminador de todas as ações militares na área social. ${ }^{104}$ Inspirada em um anteprojeto de ex-diretores do SAM, que propunha a criação de uma nova instituição

\footnotetext{
102 Enquanto o Estado priorizava a assistência e recuperação de crianças e adolescentes, a iniciativa privada, principalmente a indústria e o comércio, assumia mais diretamente e de forma organizada a responsabilidade pela formação para o trabalho. Surgia assim, em 1942, o Serviço Nacional de Aprendizagem Industrial - SENAI, seguido, em 1946, pelo Serviço Social da Indústria - SESI, Serviço Social do Comércio - SESC - e Serviço Nacional de Aprendizado Comercial - SENAC. Cf. Alvim \& Valladares, 1988.

${ }^{103}$ Ver Passetti, 1999b.

${ }^{104}$ A interessante análise de Gutemberg Alexandrino Rodrigues (2001) sobre os discursos e práticas dos militares para a questão do menor baseou-se nos discursos de Mário Altenfelder Silva, primeiro presidente da Funabem e, posteriormente, da Febem de São Paulo, na revista Brasil Jovem, publicada pelo Setor de Relações Públicas da Funabem, e em prontuários de ex-internos de três diferentes unidades da Febem-SP, entre 1976 e 1979.
} 
de assistência e tratamento desvinculada do Ministério da Justiça, ela surgiu em dezembro de 1964 com o intuito de formular e implantar a PNBEM.

A importância e a centralidade da Funabem para o Regime Militar, verificadas por sua incorporação, em 1966, ao Manual da Escola Superior de Guerra, que delineava todas as esferas consideradas prioritárias pelo governo, deveram-se à conversão da questão do menor em questão de segurança nacional. ${ }^{105}$ Para o Regime, era preciso eliminar os fatores geradores de tensão, conflito e desordem, pela implementação de um projeto desenvolvimentista, ou seja, o desenvolvimento era visto como um fator de segurança.

Assim, a implementação do desenvolvimento nacional passava pela integração de setores excluídos da ordem urbana e pelo combate à marginalidade social, o que implicava a construção de discursos e a elaboração de práticas que dessem conta de explicar e tratar essa marginalidade. Entre os discursos, e não se sabe até que ponto práticas como a perícia técnica do RPM possam ter tido alguma influência, difundia-se a concepção de marginalização como um círculo vicioso em que o estado de abandono seria o último estágio da desestruturação familiar, completado apenas pelo surgimento do menor infrator. Sendo a família a instituição produtora e reprodutora da marginalidade, caberia à Funabem reverter o processo de marginalização de crianças e adolescentes pobres.

No entanto, a relação que se visava estabelecer entre a Funabem e as famílias já não era de oposição ou substituição, como havia sido nas propostas de proteção e assistência à infância menos favorecida do início do século $X X$. As propostas do Regime Militar, elaboradas a partir de 1964, estabeleciam relações mais complexas e ambíguas. Uma primeira pista de como seriam essas relações é fornecida por Alvim e Valladares (1988), segundo as quais uma das diferenças da Funabem em relação ao SAM era a de que a reeducação do menor não dependeria mais somente da internação, mas passaria pelo apoio da família e da comunidade. A outra diferença seria uma nova concepção administrativa em que haveria uma

\footnotetext{
${ }^{105}$ Ver Alvim \& Valladares, 1988.
} 
fundação nacional responsável por ditar a política nacional e seriam criadas várias fundações estaduais responsáveis por executá-la.

Rodrigues (2001) também salienta a família como elemento privilegiado nos discursos de Mário Altenfelder Silva, um dos principais responsáveis pela criação da Funabem e seu primeiro presidente. Ele acreditava que as famílias, tanto as de elite quanto as das camadas menos favorecidas, estariam passando por um processo de desestruturação. No entanto, os efeitos dessa desestruturação eram distintos para umas e outras. Para as famílias mais favorecidas, tratava-se do problema da corrupção dos costumes, o que significava um desvio em relação ao seu papel de liderança e à formação de uma elite instauradora da ordem e condutora dos caminhos da sociedade. Para as famílias menos favorecidas, a desestruturação tinha como conseqüência a marginalização e a delinqüência.

Dito de outro modo, em uma visão funcionalista e conservadora da sociedade, a desestruturação das famílias menos favorecidas engendrava um processo de marginalização porque elas não seriam capazes de exercer suas funções de socializar e garantir a sobrevivência material dos filhos, lançando-os na miséria e na criminalidade. Essa visão aproximava-se muito daquela observada nos defensores da infância pobre do início do século $X X$, que percebiam a origem da delinqüência na ação negligente dos pais.

Para Rodrigues (2001), a diferenciação entre os dois momentos históricos poderia ser visualizada da seguinte forma: no início do século $X X$, essa visão se restringia aos discursos dos juristas, que tinham como objetivo fornecer respaldo legal para o controle de crianças e adolescentes que incomodavam o espaço público; já na década de 1960, a produção discursiva se expandiu dos juristas para médicos, pedagogos e sociólogos e visava discutir as causas do abandono e da delinqüência por meio dos aspectos biopsicossociais, isto é, biológicos (no sentido médico), psicológicos e sociais. Contudo, como salienta Alvarez (1989), a construção da categoria jurídica menor, no início do século XX, não ficou restrita aos juristas, tendo sido uma empreitada multidisciplinar que contou com o apoio de filantropos, educadores e médicos. Ademais, eles também se 
interessavam pelas causas da delinqüência e salientavam como sendo centrais a ausência ou a insuficiência dos cuidados familiares.

Então, o que havia de novo na produção discursiva que fundamentava a proposta de criação da Funabem? Ora, tratava-se da "vitimização" da família, sua conversão de instituição culpabilizada e descartada em instituição tratável, integrável ao desenvolvimento nacional, para que pudesse exercer suas funções. Ao contrário dos discursos do início do século $X X$, que defendiam a substituição dos cuidados familiares, os da década de 1960 visavam à transformação das famílias dos menores em objeto da ação de práticas corretivas. Desse modo, as instituições de assistência criadas a partir de 1960 não mais se limitariam às práticas de correção das condutas delinqüentes, mas estenderiam seu tratamento à causa dessas condutas: às famílias.

A partir da literatura revisada, não se pode afirmar em que medida, entre 1927 e 1964, as práticas de produção de saberes sobre a vida pregressa dos internados, como as perícias técnicas realizadas pelo RPM, forneceram os subsídios para a construção de discursos e práticas que estariam direcionados ao tratamento das famílias, isto é, à interferência direta sobre a vida familiar, visando transformar a ação negligente dos pais em ação eficiente. Ainda assim, Edson Passetti (1999b) esboça essa possibilidade ao apontar que a identificação dos menores, nas instituições de controle anteriores a 1964, preparou o campo para os programas interdisciplinares de reeducação inaugurados com a PNBEM. ${ }^{106}$

Com a Funabem e a PNBEM, os aspectos biopsicossociais ganhariam novos contornos e passariam a integrar o tratamento dos internados - sofisticando a antiga ideologia da pedagogia do trabalho como forma de ressocialização pelo encarceramento do início do século XX. Essa ressocialização não era mais vista apenas como uma inserção no mundo da ordem pela disciplina do trabalho, como ocorria nas Colônias Correcionais e no Instituto Disciplinar. Tratava-se de uma integração a ser gerada em diversas frentes, dentre elas, a do tratamento familiar. Nesse sentido, os prontuários contendo as informações sobre os internados, seus

\footnotetext{
${ }^{106}$ Passetti, 1999b:363.
} 
exames físicos e psicológicos, bem como a avaliação das condições socioeconômicas de seus pais ou responsáveis não eram apenas os elementos que produziam e reificavam o indivíduo menor, mas também, de 1964 em diante, constituiriam o objeto de intervenção da terapêutica institucional.

Embora não se possa falar em emergência da família como alvo de tratamento, devido às poucas informações existentes em relação ao período entre 1927 e 1964, deve-se ter em mente que, a partir daquele momento, as famílias dos internados deixavam de ser simplesmente fonte da produção de saberes sobre eles e passavam a ser objeto de intervenções práticas que atuavam em nome da reeducação e da prevenção à marginalidade. As propostas da Funabem e da PNBEM tenderiam, então, a reestruturar a estratégia de ressocialização pelo encarceramento, diminuindo a oposição entre as instituições de internação e as famílias, ao investir em sua inserção no processo ressocializador.

Nesse sentido, em 1972, surgia o Plano de Integração do Menor à Comunidade - PLIMEC, uma proposta de trabalho junto às "famílias marginalizadas", nas áreas de alimentação, saúde e educação. Cinco anos mais tarde, esse plano seria desenvolvido, em São Paulo, com algumas modificações em relação ao original, dentre elas a substituição do trabalho social voluntário pelo assalariado. $^{107}$

Em 1976, inaugurava-se a Fundação Estadual do Bem-Estar do Menor de São Paulo - Febem-SP, com os objetivos de implementar as diretrizes da PNBEM e promover a integração social dos menores por meio de programas e providências que objetivem prevenir sua marginalização e corrigir as causas do desajustamento. ${ }^{108}$ Assim, um dos principais focos de atuação institucional seria a produção de saberes que viabilizassem o planejamento de soluções para o problema do menor. No entanto, não é possível dizer em que medida esses saberes

\footnotetext{
${ }^{107} \mathrm{Na}$ literatura revisada, a única referência ao PLIMEC encontra-se no texto de Cyntia Petrocínio Figueiredo (1987), não sendo possível apontar maiores detalhes.

${ }^{108}$ Decreto 8.777 , de 13 de outubro de 1976, consultado no sítio da Imprensa Oficial do Estado de São Paulo, www.imprensaoficial.com.br, em 10 de fevereiro de 2003.
} 
acumulados podem ter influenciado a promulgação, em 1979, do segundo Código de Menores.

Porém, a literatura revisada revela que, de fato, a Febem-SP apresentou preocupação em conhecer, ou melhor, reconhecer as características da categoria menor marginalizado. ${ }^{109}$ Nesse sentido, os relatórios técnicos nos prontuários dos internados reproduziram a visão que permeava a criação da Funabem e sedimentaram a associação entre desestruturação familiar e marginalização como discurso institucional. Assim, enraizava-se a noção de que família ilegalmente constituída, desorganizada pela separação ou falecimento de um dos genitores, se despreocupava com o destino de seus filhos, lançando-os em ambientes de miséria, promiscuidade e delinqüência. ${ }^{110}$

Não obstante a literatura apontar que o item "família" era um dos mais contraditórios dos prontuários e que muitas das famílias apresentavam características que não se enquadravam naquelas preconizadas pelos discursos institucionais, a noção de desestruturação e desorganização familiar manteve-se relativamente estável. Isso porque essa noção justifica e legitima a internação como prática privilegiada ao torná-la mais adequada por oferecer os serviços de abrigo, alimentação e escola, que a família desorganizada e desestruturada não poderia assegurar. Mais uma vez, difundia-se a idéia de que a ausência ou ineficiência dos cuidados familiares justificava sua substituição pelos cuidados estatais. No entanto, havia então uma diferença, pois se tratava de substituição temporária, que visava reestruturar e re-integrar a família, "corrigi-la" enquanto causa da marginalização social.

A internação na Febem-SP manteve como efeito imediato do encarceramento uma ruptura deliberada e um distanciamento controlado em relação à vida familiar. Dito de outro modo, a internação apresenta-se como uma forma intencionalmente usada para afastar o adolescente de todo o contexto em que o ato

\footnotetext{
109 Cf. Sader, 1987; Silva, 1997; Fundação Estadual do Bem-Estar do Menor \& Faculdade de Saúde Pública, 1998; Marin, 1999; Passetti, 1999a; Rodrigues, 2001.

${ }^{110} \mathrm{Na}$ análise dos prontuários, Rodrigues (2001:193) afirma que a Febem apresenta a desagregação familiar como característica intrínseca das camadas pobres da sociedade, vivendo sem os padrões básicos da família orgânica e higiênica.
} 
infracional ocorreu e, por isso, afastá-lo também do convívio com sua família. Durante a internação, esse convívio passa a ser burocraticamente controlado, estabelecendo-se dias e horários para as visitas familiares. Assim, o primeiro lugar ocupado pela família seria o de contra-instituição, ou seja, um posicionamento que se opõe ao cotidiano institucional de duas formas.

Primeiramente, essa oposição é exercida pela própria instituição, por intermédio de todos os cerceamentos impostos à vida familiar, que vão desde os muros e cercas, passando pela revista, pelas visitas agendadas, pela necessidade de autorizações para visitas fora de horário e que envolvem também a vigilância ocular explícita do atendimento familiar institucional e implícita dos dias de visita. Em segundo lugar, a oposição pode ser exercida pelas próprias famílias, atuando em defesa de seus filhos internados. Esse posicionamento de contra-instituição oscila entre a ruidosa denúncia em face do ilegalismo institucional e as tentativas silenciosas de burlar suas regras oficiais. Atuando contra o ilegalismo institucional, algumas famílias têm denunciado as práticas corriqueiras e não-oficiais da tortura, dos maus-tratos e do abuso físico e psicológico. ${ }^{111}$ Já as tentativas de burlar as regras institucionais, como a inserção de substâncias entorpecentes dentro das unidades de internação e a conivência com eventuais fugas, requerem uma atuação silenciosa.

\footnotetext{
${ }^{111}$ Em São Paulo, um grupo de mulheres cujos filhos estavam internados nas unidades da Febem-SP criou a Associação das Mães e Amigos de Crianças e Adolescentes em Risco - AMAR, com o objetivo de organizar politicamente as denúncias de abusos, tortura e maus-tratos sofridos pelos adolescentes. Ainda atuante, essa associação procura também denunciar o mau funcionamento institucional, particularmente no que se refere à morosidade no andamento dos processos, o que significa, em muitos casos, o descumprimento dos prazos legais previstos para a internação provisória (45 dias), a medida de internação (03 anos) e a elaboração do relatório avaliativo (06 meses). Além disso, a associação procura atuar também em casos excepcionais, como o desaparecimento institucional de adolescentes. Ao longo dos quatro meses em que visitei semanalmente a associação, tive contato com dois desses casos. O primeiro deles, ocorrido antes de minha chegada, decorreu da morte e do desaparecimento do prontuário de um adolescente internado. Sem o prontuário, prova material da existência institucional do adolescente, a Febem-SP negou à mãe do adolescente que o mesmo sequer tivesse passado pela instituição. O segundo caso, que pude acompanhar, referia-se a um jovem cujo tempo de internação havia expirado, mas que estava sendo mantido na Febem-SP por meio da intensa troca de unidades, o que dificultava a sua localização por parte da família e da AMAR. Embora excepcionais, são casos de complicada comprovação, pois, na ausência de registros institucionais, fica-se entre acreditar nos familiares ou na Febem-SP.
} 
Com o fim do Regime Militar, a redemocratização do país e a promulgação da Constituição Federal, em 1988, e do Estatuto da Criança e do Adolescente, em 1990, as lutas de familiares pela garantias de direitos humanos e contra a tortura ganharam respaldo jurídico. Principalmente após a década de 1980, surgiram diversas denúncias contra as práticas cotidianas da Febem-SP que apontavam para uma percepção generalizada de que a estratégia de encarceramento se encontrava em uma profunda crise. Nesse sentido, suas unidades são lugares marcados pela constante mortificação da condição humana de adolescentes e monitores que, internalizando a hostilidade mútua, se tornam algozes e vítimas uns dos outros. Os numerosos relatos de espancamentos, torturas e maustratos apontam para a violência como tônica das relações intramuros.

Fora dos muros, rumores de rebelião levam pais e mães a se amontoarem nos portões das unidades à espera de notícias de seus filhos. Deixados do lado de fora, eles pouco podem fazer para protegê-los dos riscos a que estão submetidos pela vida intramuros. Vale ressaltar que prevenir "riscos sociais" ainda é o argumento muitas vezes usado para levar esses jovens para dentro da instituição, não obstante os riscos que eles correm estando nela. Nesse embate, fortalece-se a defesa da desinternação como forma de evitar os problemas que o encarceramento acarreta e ressaltar as qualidades socioeducativas das medidas em meio aberto, que mantêm o adolescente em sua família e comunidade de origem.

Contudo, um segundo efeito do encarceramento para as famílias é menos imediato, mais implícito e também mais duradouro. Para além da contrainstituição, os discursos que permearam a criação da Funabem, em 1964, tinham um projeto de cooptação das famílias para o processo de reeducação. Nesse sentido, a produção exaustiva de prontuários e relatórios não somente visava à produção de saberes, o estabelecimento das características consideradas "intrínsecas" ao "menor" e sua família, mas também tencionavam lançar as bases para o tratamento terapêutico. Porém, devido à grande quantidade de adolescentes internados, ao alto custo da manutenção de atendimento familiar ou às resistências veladas, mas eficazes, de diretores e funcionários em relação ao atendimento familiar, as práticas 
institucionais não deram conta de concretizar a proposta de extensão da correção de condutas para as famílias.

O legado dos discursos da década de 1960 é, portanto, o enraizamento da desestruturação familiar como causa da criminalidade a ser combatida, enraizamento esse que pode ser verificado no conteúdo dos prontuários e relatórios sociais. Já a cooptação das famílias para o processo de reeducação, prática dispersa durante o Regime Militar, reaparece com a redemocratização enquanto proposta humanista. A participação da família no processo socioeducativo, a manutenção do adolescente em sua família e comunidade de origem, a submissão dessa mesma família aos atendimentos das medidas em meio-aberto, o objetivo da liberdade assistida de promover socialmente o adolescente e sua família, fornecendo-Ihes orientação e inserindo-os, se necessário, em programa oficial ou comunitário de auxílio e assistência social, e mesmo o objetivo da internação de diligenciar no sentido do restabelecimento e da preservação dos vínculos familiares parecem apontar o quanto se perpetuam, no Estatuto da Criança e do Adolescente, as idéias de desestruturação familiar como causa intrínseca da criminalidade e de terapêutica familiar como forma de tratamento e prevenção. ${ }^{112}$

\footnotetext{
${ }^{112}$ Estatuto da Criança e do Adolescente, Art. 119, inciso I e Art. 94. inciso V, respectivamente.
} 


\title{
Capítulo III \\ (RE)SOCIALIZAÇÃO DA FAMÍLIA: OS DESAFIOS DA ATUALIDADE
}

\begin{abstract}
Nem destruída nem piedosamente conservada: a família é uma instância cuja heterogeneidade face às exigências sociais pode ser reduzida ou funcionalizada através de um processo de flutuação das normas sociais e dos valores familiares. Assim como se estabelece, ao mesmo tempo, uma circularidade funcional entre o social e o econômico. Jacques Donzelot. ${ }^{113}$
\end{abstract}

Os prontuários de adolescentes que passaram pela Febem representam uma interseção entre trajetórias individuais e institucionais, entre a experiência vivida pelo adolescente e a esperada ou imposta pela instituição. Por serem um registro oficial, tendem a materializar o olhar institucional sobre 0 indivíduo, apresentando os modos pelos quais se constroem saberes que legitimam a existência do sistema ao alimentarem o imaginário institucional sobre a categoria menor e que permitem controlar as especificidades ou desvios individuais em relação a essa categoria. Nesse sentido, a internação homogeneiza os adolescentes, produz para eles uma identidade e uma cultura desviantes em que suas condutas, suas buscas e suas expectativas são lidas pela lente da anormalidade.

A construção dessa identidade transforma os prontuários em um instrumento da produção de saberes, no qual a vida pregressa é escrutinada com o objetivo de traçar um perfil criminológico do futuro "delinqüente", aquele cujos desvios, se não corrigidos, levarão ao sistema carcerário. Não raro, essa previsão funciona como uma profecia auto-realizada, pois os mecanismos institucionais da internação tendem mais a aprofundar a inserção do adolescente nessa individualização pelo desvio do que propriamente a romper esse processo.

${ }^{113}$ Donzelot, 1986:13. 
Nesse sentido, a estratégia de encarceramento como modelo de ressocialização, adotada experimentalmente em instituições como o Instituto Disciplinar e as Colônias Correcionais e expandida, ao longo do século $\mathrm{XX}$, com o Recolhimento Provisório de Menores e, principalmente, com a Febem-SP, pode ser entendida como a constituição de um eixo socializador e individualizador destinado à produção de individualidades desviantes. Historicamente, esse eixo se construiu a partir de um duplo movimento na relação entre o Estado e as famílias pobres.

Houve, em primeiro lugar, o movimento de transferência do controle sobre a educação e a punição de crianças e adolescentes, das famílias para o Estado. Apresentado no capítulo anterior, esse movimento pode ser observado na criação de instituições públicas de recolhimento como o Instituto Disciplinar e as Colônias Correcionais, cuja fórmula de correção das condutas eram o afastamento em relação ao ambiente familiar, devido à sua "inaptidão" em conter os excessos de "liberdade" dos jovens e em encaminhá-los para o espaço de disciplina produtiva da fábrica, e o combate permanente a essa "liberdade", entendida como ócio e "vadiagem". Pode ser também assinalado com a promulgação do primeiro Código de Menores, que regulamenta e institucionaliza a perda do pátrio poder para o Estado, criando a figura do Juiz de Menores, associado a um pai supremo que assumia os cuidados sobre a infância e juventude quando a família parecia não conseguir fazêlo. ${ }^{114}$ Estabelecia-se, assim, uma tutelarização da vida familiar pelo Estado e seus representantes, por meio da vigilância e restrição de sua participação nos processos de socialização e individualização de seus filhos.

O segundo movimento foi a transformação da família em objeto da produção de saberes sobre o indivíduo desviante. Das avaliações econômicas, sociais e morais feitas por funcionários do Recolhimento Provisório de Menores aos relatórios biopsicossociais dos técnicos da Febem-SP, as instituições de internação empreenderam um certo esforço na produção de saberes e no diagnóstico da vida familiar dos internados, vistos potencialmente como futuros criminosos. Desse modo, os procedimentos institucionais indicavam a tendência de ramificação das técnicas

\footnotetext{
${ }^{114}$ Cf. Alvarez, 1989.
} 
de recuperação das condutas pelo encarceramento dos indivíduos para a correção de sua vida doméstica e íntima.

No entanto, se a inserção de inquéritos, estudos, avaliações e relatórios da vida familiar de adolescentes que se envolveram com atos ilícitos pode ser entendida como uma difusão dos controles institucionais sobre a família, ampliando-se da vigilância e restrição para a intenção de tratamento, essa difusão parece ter encontrado barreiras institucionais que dificultavam sua expansão. Para a estratégia de ressocialização pelo encarceramento, a oposição à vida familiar era uma de suas bases operacionais, pois legitimava a substituição dos cuidados familiares pelos estatais. Assim, as instituições de internação afirmavam a incompetência socializadora da família para legitimar sua existência e a aplicação de suas técnicas corretivas, de modo que a concepção de desestruturação familiar como causa da delinqüência colocava-se como uma das condições existenciais dessas instituições.

Por conseguinte, a intenção de tratamento familiar seria convertida em uma finalidade secundária para o investimento institucional, que terminaria por se concentrar na correção das condutas dos indivíduos internados. No caso da Febem$\mathrm{SP}$, embora os discursos de Mário Altenfelder, seu primeiro presidente, indicassem a ênfase no combate à desestruturação familiar como causa da marginalização social, entendida tanto como o abandono crianças e adolescentes quanto como seu ingresso na criminalidade, essa desestruturação tendeu a reafirmar o encarceramento como forma de integração social. ${ }^{115}$ De fato, dentre as finalidades e atribuições da Febem-SP, quando de sua criação, havia referências à prevenção da marginalização e correção das causas do desajustamento pela integração social do menor e, no entanto, o termo "família" não aparece em nenhum momento. ${ }^{116}$

$\mathrm{Na}$ atualidade, a relevância crescente e o destaque que a liberdade assistida tem ganhado entre os grupos de defesa dos direitos da criança e do adolescente parece significar o início de um terceiro movimento na relação entre

\footnotetext{
${ }^{115}$ Ver Rodrigues, 2001.

${ }_{116}$ Decreto 8.777, de 13 de outubro de 1976, consultado no sítio da Imprensa Oficial do Estado de São Paulo, www.imprensaoficial.com.br, em 10 de fevereiro de 2003.
} 
Estado e famílias pobres. Nesse sentido, a liberdade assistida aparece como uma possibilidade de deslocar a centralidade da estratégia de encarceramento na constituição do eixo socializador e individualizador dos adolescentes autores de ato infracional, fazendo da internação uma medida excepcional, reservada aos indivíduos refratários às suas técnicas corretivas.

Primeiramente, sua adoção em larga escala indicaria um investimento político que buscaria neutralizar os efeitos totalizadores da vida intramuros, evitar a naturalização e a interiorização de hábitos e condutas subservientes pelos adolescentes, como andar de cabeça baixa e com mãos para trás; diminuir a violência da qual se tornam sujeitos e que lhes impõe uma concepção de mundo segundo regras de força; eliminar a estigmatização que os rotula como menores ou "meninos da Febem". ${ }^{117}$ Visaria, então, retirar do corpo e da alma desses indivíduos as marcas visíveis que materializam uma história social de produção de individualidades desviantes pelas vias do encarceramento.

Em segundo lugar, o refreamento da incidência desses procedimentos totalizadores sobre os indivíduos possibilitaria a emergência de uma nova estratégia de ressocialização, que visaria a difusão das mais variadas técnicas médicas, psicológicas e sociais. Tendo a "promoção social" como objetivo, elas podem assumir as mais variadas formas, tais como terapia familiar, terapia de grupo, terapia individual, encaminhamento para programas de complementação de renda, alcoólicos anônimos, palestras sobre prevenção de doenças sexualmente transmissíveis e sobre planejamento familiar, reunião de pais e orientadores, etc. Porém, todas essas formas implicam o desaparecimento da figura do monitor, que ocupava um lugar central no encarceramento por estar em contato direto e cotidiano com o adolescente, e a reafirmação dos profissionais biopsicossociais, que tinham, como grupo técnico das instituições de internação, uma atuação menos privilegiada sobre o processo de ressocialização.

\footnotetext{
117 Sobre esses efeitos institucionais, uma boa descrição pode ser encontrada na dissertação de Paula Miraglia (2001).
} 
Em terceiro lugar, a difusão das técnicas biopsicossociais, que compõem a liberdade assistida, ampliaria seu ponto de aplicação corretiva do indivíduo para sua família. Se, no encarceramento, os procedimentos institucionais totalizadores se opunham à vida familiar, impedindo sua transformação em objeto privilegiado de tratamento, as barreiras por eles colocadas não aparecem nas técnicas da liberdade assistida, uma vez que ela não se contrapõe à vida doméstica do assistido. Assim, suas técnicas se estendem em direção às famílias, fazendo delas não somente fonte de produção de saberes sobre os desviantes, mas também alvo da intervenção terapêutica.

Desse modo, no Estatuto da Criança e do Adolescente, os orientadores sociais da liberdade assistida visam promover socialmente o adolescente e sua família, ou seja, seu objetivo seria adequar os cuidados familiares ao modelo socioeducativo. ${ }^{118}$ Por intermédio da orientação familiar, sua participação é constantemente incitada e quase exigida como signo do sucesso da ressocialização, de modo que a "promoção social" do adolescente não pode ocorrer sem a sua promoção social. Sendo ambos, adolescente e família, alvos da orientação socioeducativa, a liberdade assistida parece apontar a ascensão de novas formas de gestão do desvio por meio da regulamentação da vida familiar, para a qual se transfere a responsabilidade pela correção dos desvios individuais, ao mesmo tempo que se legitima a expansão e ramificação do controle técnico sobre ela.

Por conseguinte, sua implantação implicaria mudanças na constituição do eixo individualizador de crianças e adolescentes dos segmentos menos favorecidos da população a partir de um deslocamento das relações de poder entre Estado e família, esta passando a sofrer maior regulamentação. Tal deslocamento, que parece se fundamentar em uma concepção moderna da família como primado do educacional, transforma-a no lugar privilegiado de socialização e produção de individualidades e, portanto, de prevenção, punição e tratamento das condutas desviantes.

\footnotetext{
${ }^{118}$ Inciso I do art. 119, Estatuto da Criança e do Adolescente.
} 
Este capítulo busca aprofundar a reflexão sociológica sobre essa dupla mudança de reafirmação da importância da família como instituição socializadora e individualizadora e do aumento de sua regulamentação estatal no que se refere, justamente, à socialização e individualização dos jovens. Procura-se, assim, abordar uma e outra a partir de contribuições sociológicas modernas e contemporâneas sobre socialização, individualização, família e controle estatal.

Efetivamente, essas questões têm sido exaustivamente colocadas desde a modernidade e a ascensão do indivíduo moderno, sendo ele o resultado da destradicionalização da sociedade e da conseqüente possibilidade de construção da própria identidade. Nesse sentido, há um aparente consenso entre diferenciados autores e correntes teóricas no que se refere à interferência social - seja do Estado, da escola, dos médicos ou de profissionais sociais - na vida familiar como característica intrínseca à modernização e à individualização. Porém, os resultados dessa interferência e a possibilidade de que a família seja, nas condições modernas e contemporâneas, a instituição central dos processos de socialização e individualização parecem ser os focos de polêmica sociológica. Apresentar algumas das contribuições sobre ela é o que se propõe a seguir.

\section{A família moderna e a socialização: o problema da padronização.}

Na primeira metade do século $X X$, quando as separações, as uniões estáveis e as famílias recompostas, monoparentais ou unipessoais não eram consideradas um fenômeno representativo da população como são nos dias atuais, parecia fazer sentido pensar a família como uma instituição socializadora, com uma estrutura relativamente rígida e um conjunto de regras prescritas e fixas. ${ }^{119}$ De certa

\footnotetext{
${ }^{119}$ Segundo Rosa Ribeiro et alii (1998), o peso das famílias constituídas por casal com filhos tem apresentado tendência de redução, tendo passado de $65 \%$, em 1981, para 60,9\%, em 2000 . Em contrapartida, houve crescimento das formas alternativas de organização doméstica, destacando-se as unidades domésticas unipessoais e as famílias formadas por mulheres sem cônjuge com filhos, que representavam 13,7\%, em 1990. O Censo de 2000 parece também apontar o crescimento desse último tipo de organização familiar, de modo que $24,9 \%$ dos domicílios brasileiros eram chefiados por mulheres. Dados retirados do sítio oficial do IBGE, www.ibge.com.br, em 25 de agosto de 2004.
} 
forma, havia uma definição conhecida, compartilhada, sentida ou vivida do que seria uma família. Ela poderia ser considerada um conceito social e sociologicamente institucionalizado que encerrava uma estrutura composta pelas relações mais imediatas de conjugalidade (esposos) e de consangüinidade (pais e filhos) e que prescrevia os papéis sexuais e as funções intergeracionais a serem seguidos por cada um de seus membros.

Se constituir uma família era casar-se e ter filhos, a criação de um novo núcleo familiar envolvia, primeiramente, um rito de reconhecimento do casal, por meio de uma aliança firmada perante a Igreja e o Estado. Assim, desde o início da modernização da sociedade brasileira, no século XIX, o matrimônio passou por profundas mudanças, deixando de ser uma aliança entre linhagens sacramentada pela lgreja para tornar-se uma união entre indivíduos, resultante de uma escolha "irracional" advinda da afetividade entre os esposos. ${ }^{120}$ Essas mudanças refletiam-se também na finalidade do casamento, que não mais significava a preocupação com a ascendência dos noivos e que, doravante, passaria a ter como razão de ser o investimento no futuro e a preocupação com a descendência do casal. ${ }^{121}$

Uma vez formado o núcleo familiar, caberia aos seus membros adultos a identificação com papéis sociais e sexuais padronizados, nos quais o homem se tornaria o "provedor" ou "chefe de família", responsabilizando-se pela mediação entre a esfera privada da família e o mundo público por meio de sua inserção no mercado de trabalho assalariado, e a mulher, a "dona de casa" ou "rainha do lar", voltada para manutenção interna do núcleo familiar.

Fosse por uma suposta fragilidade para lidar com o mundo público ou pela alegada "instabilidade de nervos", isto é, pela atribuição que lhe era feita de um conjunto de características e distúrbios biopsíquicos, como a histeria, a mulher foi

\footnotetext{
${ }^{120}$ Sobre as mudanças do casamento na sociedade brasileira, cf. Souza, 1951; Costa, 1999.

${ }^{121}$ No século XIX, o surgimento da ênfase na infância e na descendência, característica da família nuclear moderna, não implicou a desvalorização social da ascendência e da linhagem. Nesse sentido, o século da higienização familiar em nome da saúde da prole foi também marcado pelo ápice das genealogias em São Paulo, que buscavam conferir legitimidade à elite cafeicultora emergente por meio da construção histórica de uma ancestralidade notável ou nobre, apagando da memória social seu passado de pobreza e de desvios em relação ao modelo patriarcal do período colonial e criando um mito de origem da "família de quatrocentos anos". Ver Marins, 2002; Cruz, 2002.
} 
relegada ao espaço protegido da vida privada, tornado-se sua representante no imaginário social. Por conseguinte, os papéis sociais possíveis para a mulher casada cerceavam-na ao privado, privavam-na do público, lançavam-na em uma vida cujo sentido existencial eram os outros, e diziam respeito a ser uma esposa dedicada ao marido e uma mãe afetuosa para os filhos.

Não obstante a hierarquização entre os membros adultos, sendo a família moderna por vezes descrita como patriarcal devido ao predomínio masculino, seu foco não se dirigia às relações conjugais de gênero, mas às relações consangüíneas intergeracionais. ${ }^{122}$ Como dito anteriormente, o casamento e a criação de um novo núcleo familiar tinham como finalidade assegurar a descendência e a posteridade por meio dos filhos. Esse itinerário familiar traçado a partir da preocupação com o porvir esvaziou a importância do homem patriarca, transferindo-a para a criança, que se transformara no símbolo do futuro com, pelo menos, dois significados. O primeiro deles referia-se à perpetuação da instituição familiar por meio de seus herdeiros, que, atingindo a idade adulta, iriam recomeçar o ciclo, constituindo um novo núcleo. O segundo era a reprodução da sociedade nas novas gerações, pois a família era o grupo social mais simples e imediato com o qual a criança teria seu primeiro contato.

A questão que se colocava (e, de certo modo, ainda se coloca) para a reflexão sociológica era em que medida essa instituição familiar moderna, reduzida às relações entre esposos e entre pais e filhos, poderia assegurar a reprodução da sociedade nas novas gerações. Historicamente, tal reflexão emergiu entre o final do século XIX e o início do século XX, período em que o problema do indivíduo moderno e de sua formação social mobilizava as atenções de diversos pensadores.

\footnotetext{
${ }^{122}$ Segundo Jeni Vaistman (1995), a família conjugal moderna seria uma instituição ao mesmo tempo individualista e patriarcal porque estaria estruturada em uma valorização da relação afetiva e contratual entre dois indivíduos e em uma prática de divisão sexual do trabalho, hierarquizando os sexos e colocando a mulher em posição subordinada e excludente da possibilidade de participação nas práticas públicas e na individualização. Cynthia Sarti (1994), por sua vez, assinala que as famílias pobres da periferia de São Paulo, ao seguirem padrões patriarcais de autoridade e hierarquia, estariam reiterando valores tradicionais coloniais e dificultando a afirmação individual do homem e da mulher. Sobre os traços patriarcais da família moderna, cf. também Castells, 1999.
} 
Na perspectiva de Émile Durkheim (1947), a base dessa formação era a educação, entendida especificamente como a ação exercida assimétrica e hierarquicamente pela geração de adultos sobre a geração de jovens. Buscando regulamentar as ações humanas e direcionar as condutas individuais rumo a fins sociais, a educação das crianças envolveria o aprendizado de regras por intermédio da instauração do espírito de disciplina desde a infância, o envolvimento com o social pela adesão a um grupo social e o reconhecimento racionalizado das regras, gerando uma autonomia da vontade que muito se aproximava de uma identificação com as regras. ${ }^{123}$

Nesse processo de educação, a família moderna ocuparia um lugar secundário, pois, embora seja o primeiro grupo social ao qual a criança adere e com o qual se envolve, não lhe seria possível instaurar o senso do dever, ou seja, o espírito de disciplina e a autonomia da vontade.

Por um lado, a família despertaria os sentimentos domésticos e ofereceria à criança a sensação de amparo do grupo, que tornaria a sociedade algo desejável. Seria também a instituição onde a educação teria início, no sentido de fazer com que a criança contraísse hábitos regulares, ou seja, a vida doméstica criaria a afeição pela regularidade, preparando a criança para a vida social. Ademais, por intermédio dos pais, a família despertaria um primeiro sentimento de autoridade, que, no entanto, não se poderia desenvolver no meio familiar.

Por outro lado, contudo, a noção de autoridade, fortemente relacionada ao respeito à regra, aparecia na família moderna de modo rudimentar devido ao caráter pessoal e relativamente eletivo de suas relações. Sendo um grupo reduzido, suas relações seriam marcadas pela intimidade e pelo contato pessoal, o que prejudicaria a regulamentação dos deveres domésticos baseada em preceitos gerais e definidos que se aplicariam sempre da mesma maneira, deixando-os suscetíveis à diversidade de caráter e de circunstâncias. Como o aprendizado do

\footnotetext{
${ }^{123}$ As contribuições de Émile Durkheim sobre a formação das novas gerações pela educação encontram-se, principalmente, na publicação de seu primeiro curso lecionado na Universidade de Sorbonne, entre 1902 e 1903 (e repetido entre 1906 e 1907). Cf. Durkheim, 1947. Ver também Durkheim, 1978; Fernandes, 1994.
} 
respeito à regra se daria de modo incompleto na família, deveria ser efetuado pela escola.

A partir da década de 1950, a influência da psicologia social levaria a novos desdobramentos da sociologia da família, que passaria a revisar o lugar ocupado por ela na reprodução individual da vida social. Com a influência da psicologia, questões como o aprendizado do respeito à regra e o senso do dever tornaram-se conseqüências da adesão ao grupo social, que se transformou no ponto-chave da discussão sobre o processo de socialização. Assim, os aspectos emocionais, a intimidade e a pessoalidade das relações familiares deixaram de ser vistos como entraves e tornaram-se essenciais na internalização da vida social, conferindo sentido e motivação às suas regras. ${ }^{124}$

Esse resgate da centralidade da família caracterizou a contribuição de Talcott Parsons (1960), que, juntamente com colaboradores, procurou abordar a socialização por meio da interseção entre o conceito psicológico de personalidade e a teoria sistêmica. ${ }^{125}$ Para o autor, o funcionamento de uma sociedade dependeria da relação entre a personalidade individual e o sistema social, na qual o indivíduo aprenderia, desenvolveria e manteria uma motivação adequada ao comprometimento com os valores sociais. ${ }^{126}$

Visando estabelecer essa relação, a socialização deveria organizar a personalidade da criança por meio da internalização e da reprodução dos papéis sociais mais simples vivenciados na família. A família nuclear moderna, entendida como um subsistema social, apresentaria um nível muito elementar de diferenciação de papéis, distribuídos conforme geração e gênero nas formas de pai/marido, mãe/esposa, filho/irmão e filha/irmã. Ao aprenderem a representar esses papéis

\footnotetext{
${ }^{124}$ Sobre essa questão ver Lasch, 1991; Singly [1993].

125 Segundo Christopher Lasch (1991:151-76), Talcott Parsons e seus colaboradores do Departamento de Relações Sociais de Harvard, criado em 1950, procuraram construir uma teoria sistêmica do comportamento humano que incorporasse a psicanálise por intermédio do estudo da dinâmica de pequenos grupos sociais. Nessa dinâmica, a família nuclear moderna seria entendida a partir das noções de liderança instrumental e expressiva, segundo as quais o pai/marido seria o líder instrumental do grupo familiar, responsabilizando-se pelas relações externas entre esse e outros grupos sociais, e a mãe/esposa, a líder expressiva, assegurando a estabilidade das relações internas. Ver também Parsons et alii, 1960.

${ }^{126}$ Cf. também Parsons, 1969.
} 
sociais simples, as crianças internalizariam uma estrutura primária de personalidade a partir da qual novos papéis, progressivamente mais complexos, poderiam ser aprendidos e organizados.

Porém, a função da família no processo de aprendizado dos papéis sociais não se resumiria à sua simplicidade. Nesse sentido, o envolvimento emocional característico da interação entre a criança e sua família seria o estímulo indispensável que levaria aquela a aprender a desempenhar os papéis apropriados. Por meio desse envolvimento, a estrutura de personalidade da criança também internalizaria os mecanismos de motivação necessários para participar de padrões de ação socialmente valorizados, tornando-se um adulto comprometido com os valores sociais.

Afirmando a função familiar de edificação da personalidade das crianças, fosse pelo aprendizado de papéis sociais ou pela motivação para representá-los, Talcott Parsons e seus colaboradores (1960) asseguravam à família a centralidade na reprodução da sociedade nas novas gerações e, portanto, no processo de socialização. Ao mesmo tempo, demonstravam a influência que a perspectiva psicológica teria nas teorias da socialização, ao enfatizar a questão do envolvimento emocional como chave da internalização do social. ${ }^{127}$ Essa questão seria aprimorada a partir da década de 1960, com o desenvolvimento do interacionismo simbólico.

Nessa perspectiva, a importância da família relacionava-se aos efeitos cognitivos produzidos pelas interações com os outros significativos, que lançariam as bases para a internalização do outro generalizado, isto é, da sociedade. Por intermédio da família, a criança seria inserida no mundo da linguagem, dos valores e dos papéis sociais em um ambiente fortemente carregado pelo envolvimento emocional com os agentes socializadores.

\footnotetext{
${ }^{127}$ Contudo, segundo Christopher Lasch (1991:159-64), o envolvimento emocional na interação entre a criança e a família era visto de forma contraditória por Talcott Parsons. Embora este reconhecesse sua importância para a formação da personalidade, havia, para ele, a constante possibilidade de que seu excesso produzisse tensões e desequilíbrios prejudiciais à segurança emocional da criança e, por conseguinte, à formação da sua personalidade.
} 
O processo de socialização, enquanto esquema universal de desenvolvimento do ser humano, dividir-se-ia em duas fases, sendo a primeira delas a socialização primária com os outros significativos da família, em que o envolvimento afetivo levaria à introdução dos mecanismos de identificação pelos outros e de auto-identificação. De imediato, a socialização primária constrói o primeiro mundo social concreto do qual o indivíduo faz parte e, assim, funda as bases que tornam possível uma abstração progressiva dos papéis e atitudes dos outros significativos, particulares e concretos, em direção a papéis e atitudes em geral, formando o outro generalizado. Essa formação é decisiva para a socialização, pois implica a interiorização da sociedade como realidade objetiva ao mesmo tempo que estabelece uma identidade subjetiva corrente e contínua. A fase primária só se conclui quando o conceito de outro generalizado foi estabelecido na consciência do indivíduo, cabendo à socialização secundária, que envolve a escolarização, criar mecanismos de interiorização dos submundos institucionais. ${ }^{128}$

Ao buscar estabelecer um esquema universal de desenvolvimento do ser humano, o interacionismo simbólico se aproximava tanto de Émile Durkheim quanto de Talcott Parsons, no sentido de visar uma padronização teórica para o processo de socialização. O objetivo comum a essas perspectivas seria apontar os padrões ideais pelos quais a socialização pudesse assegurar a produção social dos indivíduos. Além disso, se elas apresentavam diferentes leituras sobre a importância da família nessa produção, tinham, por outro lado, um pressuposto comum, a saber, uma concepção padronizada de família como um grupo social reduzido às relações marcadamente afetivas entre pais e filhos.

\footnotetext{
${ }^{128}$ Ver, principalmente, Berger e Luckmann, 1999; também, Berger \& Berger, 1977.
} 


\section{Famílias contemporâneas e socialização: o problema da incerteza}

$\mathrm{Na}$ contemporaneidade, esse pressuposto deixa de existir, isto é, a família se torna um caleidoscópio de possibilidades de vida íntima, o que inviabiliza compartilhar uma concepção homogênea ou padronizada dela. De fato, a tendência de desinstitucionalização da família e a conseqüente fragmentação da socialização pela via doméstica são alguns dos desafios que se colocam à reflexão sociológica contemporânea.

Nesse sentido, o declínio do modelo familiar moderno, baseado na conjugalidade, com sua divisão sexual do trabalho, e nas relações inter-geracionais, transformou os contextos de socialização familiar em algo incerto, instável e de difícil prescrição. Desde a década de 1970, diferentes formas de vida íntima ganharam visibilidade e abalaram o primado da configuração marido e esposa, pais e filhos como única forma legítima de experiência familiar. ${ }^{129}$ Dentre elas, a dissolubilidade dos laços matrimoniais, com o crescimento das famílias monoparentais e da recomposição familiar, criou novas possibilidades de educação das crianças pela redução ou ampliação do contato com os adultos. Assim, ocorreu um processo de desinstitucionalização da família, uma vez que suas relações se tornaram menos prescritas e não servem mais de guia para o que se pode esperar do futuro, ou seja, já não há um controle das incertezas pelo estabelecimento de um padrão familiar. ${ }^{130}$

Diante desse quadro, a proposta indicada pelo Estatuto da Criança e do Adolescente, de afirmação da família no processo de ressocialização e, principalmente, de construção de identidades, parece deslocada. Por um lado, na liberdade assistida, a inserção da família como objeto de intervenção terapêutica indica que ela é considerada uma instância central na formação das pessoas em desenvolvimento, isto é, dos adolescentes. Por outro lado, no entanto, o contexto atual de incerteza com relação às organizações familiares lança dúvidas sobre a

\footnotetext{
${ }^{129}$ Ver Beck e Beck-Gernsheim, 2002.

${ }^{130}$ Sobre o conceito de instituição como controle das incertezas com relação ao futuro, cf. Douglas, 1986.
} 
possibilidade de continuarem sendo instituições socializadoras e individualizadoras centrais.

Nesse esteio, Claude Dubar (2001) assinala que a contemporaneidade se caracterizaria pela substituição do indivíduo conformado por regras e normas pelo indivíduo-trajetória, lançado à conquista de sua identidade pessoal. ${ }^{131} \mathrm{~A}$ ascensão do indivíduo-trajetória, associada à ampliação das possibilidades de escolha e das variações na biografia individual, ao declínio de formas institucionalizadas e padronizadas de vida - como no caso da família - e ao aumento da valorização social de biografias autênticas, teria como conseqüências a intensificação das experiências de crise ou ruptura no nível individual e o enfraquecimento, no nível social, do modelo de estabilização da identidade pelas instituições, que assegurava uma continuidade linear do aprendizado de papéis sociais e da construção identitária, desde a infância até a idade adulta.

Conseqüentemente, no nível sociológico, a ascensão do indivíduotrajetória inviabilizaria a leitura do processo de socialização como determinação da identidade pessoal por condições sociais. Em contrapartida, delinearia uma outra leitura na qual essa identidade seria construída a partir dos recursos da trajetória social que é também uma história subjetiva. ${ }^{132}$ Tal leitura parece implicar um deslocamento do foco de análise da socialização das instituições para os indivíduos, acentuando a questão da subjetividade, enfatizada pelo interacionismo simbólico, e, ao mesmo tempo, diminuindo sua proximidade com a abordagem sistêmica de Talcott Parsons et alii (1960). ${ }^{133}$

Segundo Claude Dubar (2002), a construção da identidade pessoal darse-ia a partir de um dualismo irredutível na socialização, isto é, de dois processos heterogêneos que co-existem e não necessariamente coincidem. O primeiro deles seria a atribuição de identidades sociais pelos outros, as instituições ou os atores

\footnotetext{
${ }^{131}$ Ver Dubar, 2001:165.

${ }^{132}$ No original: L'identité personnelle (...) est construite à partir des ressources de la trajectoire sociale qui est aussi une histoire subjective. (Dubar, 2001:198).

${ }^{133} \mathrm{O}$ aprendizado e a internalização de papéis sociais pela criança na interação marcadamente afetiva com os pais são abordados tanto pelos interacionistas quando por Talcott Parsons et alii (1960). Porém, é o interacionismo que enfatiza a dimensão subjetiva da criança nesses processos. Nesse sentido, ver Berger \& Luckmann, 1999:173-84.
} 
que interagem diretamente com indivíduo. O segundo, por sua vez, seria a forma como ele as incorpora, ou seja, a construção de uma identidade por si.

Para diminuir a distância entre esses dois tipos de identidade, haveria duas estratégias individuais centrais à socialização. ${ }^{134}$ A primeira seria a transação objetiva, na qual o indivíduo procuraria acomodar a identidade atribuída por outro e a identidade construída por si por intermédio da negociação com o outro. Essa transação pressupõe que a negociação identitária não seja uma etiquetagem automática, mas um processo complexo de comunicação em que a possibilidade de confrontação entre as demandas individuais e as ofertas de identidades sociais tende a forçar uma redefinição das categorias pelas quais essas últimas são construídas. ${ }^{135}$ A segunda seria a transação subjetiva e implicaria a tentativa de assimilação interna da identidade atribuída por outro àquela construída por si. Tratarse-ia, desse modo, da construção da identidade pessoal a partir do confronto subjetivado entre o desejo, a expectativa individual e as identidades sociais, oferecidas e internalizadas.

$\mathrm{Na}$ contemporaneidade, essas transações ocorreriam em um contexto no qual não haveria uma definição de novas identidades sociais atribuídas pelas instituições, ao mesmo tempo que as antigas não seriam mais suficientes para assegurar aos indivíduos um controle sobre as incertezas do futuro. Nesse sentido, as instituições teriam se flexibilizado, de modo a combinar elementos comunitários tradicionais, que determinam normas, regras e papéis, com elementos societários, que oferecem possibilidades e recursos à construção da identidade pessoal.

O laço societário seria uma associação voluntária e temporária de indivíduos que, buscando defender interesses comuns e/ou compartilhar valores por intermédio de parcerias, estabeleceriam uma sociabilidade eletiva que tem uma significação subjetiva ao mesmo tempo que reconhece no parceiro um ator pessoal e social. Desse modo, Claude Dubar (2001) indica que a saída para a crise identitária, ocasionada pela dissolução das formas comunitárias e pela individualização das

\footnotetext{
${ }^{134}$ Sobre os processos e mecanismos de socialização ver Dubar, 2002:109-14.

135 Sobre negociação e interação com outros significativos, cf.também Berger \& Luckmann, 1999.
} 
ações institucionais, seria a afirmação da sociabilidade societária, entendida como emancipadora, por implicar maior autonomia nas escolhas individuais. ${ }^{136}$

No que se refere à família, o casamento seria um exemplo sintomático da mudança institucional societária, uma vez que mulheres e homens tenderiam cada vez mais a negar a conjugalidade comunitária instituída, com identidades sociais pré-estabelecidas, e a aspirar um nós societário, uma parceria baseada no amor e na incerteza. Assim, a vida conjugal contemporânea torna-se cada vez menos padronizada e mais flexível, individualizada e desinstitucionalizada.

Porém, quando as mudanças envolvem a relação pais e filhos, a análise da construção identitária é mais complexa. Para Dubar (2002), as esferas do trabalho, do emprego e da formação escolar tornaram-se os domínios de identificação social dos indivíduos, adquirindo centralidade histórica crescente a partir da segunda metade do século XX. O momento essencial de construção da identidade autônoma dar-se-ia entre a saída do sistema escolar e a confrontação com o mundo do trabalho, e não na relação do jovem com a família. ${ }^{137}$

Nesse sentido, a análise do autor parece indicar que, com a ascensão do indivíduo-trajetória e das formas societárias de construção das identidades, a família contemporânea, desinstitucionalizada, perdeu a centralidade no processo de socialização das gerações mais novas. Por um lado, ela transformou-se em uma intimidade eletiva, baseada na parceria entre homem e mulher e nas negociações das identidades afetivo-sexuais e de gênero entre indivíduos adultos. Por outro, o aprendizado, a internalização e a negociação das demais identidades pelas crianças deslocaram-se para outras instituições que, como a escola, visam principalmente a inserção no mercado de trabalho.

A relevância da escolarização e do mercado de trabalho como eixos socializadores do indivíduo contemporâneo, associada ao declínio da importância da família nesse processo, foi também assinalada por Ulrich Beck e Elizabeth BeckGernsheim (2002). Segundo esses autores, na atualidade, a individualização seria,

\footnotetext{
${ }^{136}$ Ver Dubar, 2001:198-2003.

${ }^{137}$ Cf. Dubar, 2002:115-8.
} 
justamente, o resultado de uma socialização complexa e contingente, impulsionada tanto pela expansão das instituições educacionais implementadas pelo Estado de Bem-Estar Social quanto pelo mercado de trabalho. Nessa perspectiva, a individualização significaria a aquisição e ampliação de habilidades de trabalho por meio da obtenção de credenciais educativas, abrindo oportunidades individuais de carreira no mercado de trabalho, da demanda de mobilidade pelo mercado, que implicaria a ruptura com vínculos tradicionais, e da competição entre iguais, que dissolveria a comunidade e isolaria os indivíduos de grupos sociais homogêneos. ${ }^{138}$

A conseqüência mais imediata desse processo seria a desintegração dos estilos de vida e das formas tradicionais de sociabilidade, quais sejam, a família, a comunidade, a classe e o status social. Nesse sentido, ao criar diferenciações internas nos grupos sociais, a espiral individualizante destruiria as antigas bases de coexistência social, desencaixando e desenraizando os indivíduos de vínculos sociais tradicionais sem re-encaixá-los ou produzir novos tipos de vínculos duradouros ou estáveis. Contudo, a ausência de re-encaixe não significaria que os controles e constrangimentos sociais deixem de existir. Eles transformaram-se de modo a incitarem constantemente os indivíduos à construção de biografias que se adaptem a condições sociais fluidas, sejam elas as de mercado de trabalho ou referentes ao sistema de educação e ao Estado.

Diferentemente de Dubar (2001), que assinala o declínio das formas tradicionais de sociabilidade como uma possibilidade de emancipação e autonomia do indivíduo, Beck e Beck-Gernsheim (2002) apontam que esse declínio estaria relacionado a uma individualização institucionalizada, ou seja, à constituição de uma estrutura social individualizante cujos processos contínuos não-lineares, de possibilidades ilimitadas e ambivalentes, visariam produzir soluções biográficas para contradições sistêmicas. As biografias individuais assim constituídas seriam de risco, pois, ao mesmo tempo que o indivíduo é compelido a tomar decisões, ele não ocupa uma posição que possibilite avaliar prováveis conseqüências e fazer escolhas de maneira racional e refletida. Dessa forma, o indivíduo contemporâneo seria mais

\footnotetext{
${ }^{138}$ Ver, principalmente, Beck \& Beck-Gernsheim, 2002:30-41.
} 
anômico que autônomo, aproximando-se do conceito de anomia como ausência de regulação e se afastando de uma noção de autonomia iluminista pelo conhecimento da razão ou de suas leis. ${ }^{139}$

A conseqüência específica desse processo para a vida familiar, colocada pelos autores, seria a transformação das relações familiares, de uma comunidade de necessidade, em uma constelação de diferentes relações eletivas. Historicamente, a primeira ruptura dessa comunidade viria com a individualização produzida pela constituição do mercado de trabalho e a perda das funções econômicas que asseguravam à família pré-industrial a manutenção de propósitos e objetivos comuns entre seus membros, por intermédio de uma obrigação de solidariedade. No entanto, essa obrigação não teria deixado de existir com o surgimento da família moderna industrial, mas adquirido uma nova forma com a divisão sexual do trabalho, que só viria a enfraquecer-se com a expansão da individualização pelo Estado de Bem-Estar Social. Estabelecer-se-ia, assim, um novo estágio na relação entre família e indivíduo, no qual as políticas de equalização do acesso à educação entre homens e mulheres assim como a entrada no mercado de trabalho e a seguridade social como garantias de uma existência mínima fora da família levaram a profundas mudanças nas biografias femininas, incentivando-as a desenvolverem-se para além do espaço privado familiar. ${ }^{140}$

A individualização de mulheres e homens causaria o rompimento da obrigação de solidariedade dos vínculos familiares juntamente com a capacidade de determinação de um modelo familiar por regras tradicionais. Tornando-se um dos aspectos da construção de biografias de risco, a família contemporânea passaria a ser uma constelação de diferentes relações eletivas em que é impossível determinar o que é normal e o que é desvio. Nesse sentido, o declínio do modelo normal marcaria a ascensão da era da família autodeterminada, a qual compele seus membros a permanentes escolhas sem que, contudo, isso signifique a eliminação de contradições ou a diminuição de riscos. Isso implica dizer que, não obstante a

139 O conceito de individualização institucionalizada usada por Ulrich Beck e Elizabeth BeckGernsheim remete à obra de Talcott Parsons. Já a noção de anomia refere-se à contribuição de Émile Durkheim. Cf. Beck \& Beck-Gernsheim, 2002.

${ }^{140}$ Cf. principalmente Beck \& Beck-Gernsheim, 2002:85-100. 
equalização da educação e a seguridade social, haveria a manutenção de uma estrutura institucional familiar e de comportamentos sociais que pressupõem desigualdades de gênero e produzem descompasso entre as expectativas de igualdade e as experiências biográficas de desigualdade. ${ }^{141}$

Conseqüentemente, o foco de tensão das famílias contemporâneas, ou das famílias pós-familiares, para usar a expressão de Beck e Beck-Gernsheim (2002), vincular-se-ia às relações de gênero. Desse modo, mulheres e homens experimentariam continuamente a construção de um espaço de intimidade, a partir de laços contingentes e fragilizados pela ausência de um aparato público que minimize os impactos da economia de mercado na vida privada. Essa ausência distribuiria de forma desigual as conseqüências e os riscos da paternidade e da maternidade, fazendo com que as mulheres estejam mais expostas aos riscos ocupacionais, financeiros e existenciais de ter filhos, pois a maternidade, sem um aparato público para o cuidado das crianças, limita suas chances no mercado de trabalho.

Contudo, o cuidado das crianças, isto é, a vertente inter-geracional da socialização contingente e complexa que produz indivíduos é pouco abordada pelos autores. Focalizando os conflitos familiares de gênero em relação às demandas de mercado, sua análise se limita aos problemas da individualização em uma sociedade de adultos cujo pressuposto é a equalização da educação formal das crianças. No entanto, as especificidades ou as formas de operacionalização dessa equalização não são abordadas.

Nesse sentido, a contribuição de François de Singly [1993, 1996a, 1996b] parece ser mais completa, pois procura abordar as transformações da família contemporânea tanto no que se refere às relações intra-geracionais entre homens e mulheres quanto ao que remete às relações inter-geracionais entre pais e filhos. ${ }^{142}$

\footnotetext{
${ }^{141}$ Sobre a discussão de gênero e família na modernidade e na contemporaneidade, cf. também Beck, 1992; Vaistman, 1995.

${ }^{142}$ Cabe ressaltar a importância do clássico estudo de Philippe Ariès (1981), que abordou as transformações nas relações familiares a partir da valorização da infância e serviu de base para estudos e reflexões posteriores.
} 
Com relação às transformações na conjugalidade, François de Singly [1996a, 1996b] aponta a família menos como uma instituição e mais como o espaço das relações afetivas, no qual as interações entre homem e mulher ofereceriam um sentido social para as escolhas identitárias individuais. O retorno à família pelos indivíduos adultos dar-se-ia juntamente com a ascensão de uma concepção de indivíduo que desvaloriza os papéis pré-estabelecidos e exalta a originalidade e a autenticidade. Essa busca permanente de si na sociedade contemporânea demandaria a continuidade das ligações com os outros muito próximos ou significativos, permitindo aos indivíduos escaparem de um fechamento identitário em si mesmos ao criar um espaço para relações de diálogo com outros significativos. Desse modo, a família possibilitaria articular a busca da realização de si e a preocupação com o outro, a valorização do indivíduo e a produção de um interesse coletivo, a partir da construção de um senso de responsabilidade nas relações com os outros significativos, o que conferiria sentido subjetivo a uma coação, sujeição ou restrição social proveniente de papéis, posições ou status e as transformaria em uma decisão ou compromisso pessoal. ${ }^{143}$

Porém, é na discussão das relações inter-geracionais entre pais e filhos que a análise de François de Singly [1993] se diferencia das anteriormente apresentadas e, por isso, se torna esclarecedora. Segundo o autor, de modo geral, as relações familiares seriam caracterizadas por um duplo movimento: de pessoalização, com o crescimento e a valorização da afetividade e da intimidade entre os indivíduos, e de socialização, com o surgimento e a intensificação da intervenção do Estado na vida privada. ${ }^{144}$

Em nome do interesse pela infância e pela formação das novas gerações, a intervenção estatal buscaria regulamentar, sustentar e controlar as relações familiares, tornando-as dependentes da esfera pública não obstante suas reivindicações por maior independência coletiva e individual. Por um lado, a interferência do Estado asseguraria a individualização, ao garantir a independência da família em relação aos laços de parentesco, da mulher em relação ao homem e

\footnotetext{
${ }^{143}$ Ver Singly, [1996a, 1996b].

${ }^{144}$ Cf. também Déchaux, 1995.
} 
da criança em relação aos pais, seja por meio do estabelecimento de regras e leis, seja fornecendo subsídios econômicos. Por outro lado, isso implicaria menor autonomia em relação aos representantes do Estado.

Ainda assim, o autor salienta a redução da tensão entre as famílias e a esfera pública na contemporaneidade, pois o Estado tenderia a intervir mais como apoio do que como controle. Com o crescimento do número de divórcios e de famílias recompostas, a socialização familiar tornou-se complexa a tal ponto que o estabelecimento de regras fixas de matrimônio e criação dos filhos pelo Estado teria perdido sua eficácia simbólica. Em contrapartida ao recuo do controle estatal, estaria presente a ascensão dos controles psicológico e psicanalítico, ou seja, a regulamentação familiar tornar-se-ia cada vez mais dependente de especialistas do complexo "psi".

A intervenção de especialistas e conselheiros na vida familiar parece ser o ponto de passagem do duplo movimento de pessoalização e socialização das famílias contemporâneas. Centralizando as relações pessoais e transformando a família em um lugar de intimidade tensa, a pessoalização geraria a demanda constante por serviços psicológicos, tanto no foco da sexualidade quanto no da infância, que fazem da família "normal" uma consumidora de serviços psicológicos terapêuticos. Estes, além de estabelecerem critérios de normalidade, produziriam também novas formas de estigmatização social, desvalorizando certos modos de organização doméstica. Por conseguinte, para Singly [1993], se houve a diminuição da estigmatização no nível estatal, ela se mantém em canais menos formais, como o de especialistas psicológicos. ${ }^{145}$

Ao aprofundar a discussão dos controles externos sobre a vida familiar a partir do interesse pela infância e da formação das novas gerações, a abordagem desse autor contribui mais diretamente para a reflexão teórica sobre a afirmação da importância da família no processo de ressocialização de adolescentes. Nesse sentido, enquanto Dubar (2002), Beck e Beck-Gernsheim (2002) vêem a expansão da escolarização pelo Estado como pressuposto da formação do indivíduo

\footnotetext{
${ }^{145}$ Para a discussão específica do significado do estigma com relação às identidades individuais, ver Goffman, 1988.
} 
contemporâneo e direcionam-se para a discussão das mudanças na vida familiar pela perspectiva dos adultos, a análise de Singly [1993] aponta que o deslocamento do eixo de individualização, da família para outras instituições, por meio da interferência do Estado na vida íntima moderna, não é um processo simples ou acabado, havendo diferentes formas de controle que visam regulamentá-lo. ${ }^{146}$

$\mathrm{Na}$ sociedade brasileira, esse controle estatal sobre a família, no sentido do estabelecimento de regras fixas para o matrimônio e a criação dos filhos e da padronização de um modelo único de família, caracterizado pela desigualdade entre a mulher e o homem e pela centralidade da relação entre pais e filhos, teria também entrado num momento histórico de recuo. Nesse sentido, ao analisar as posições jurídico-doutrinárias com relação às famílias brasileiras, Andrei Koerner (2002) assinala que a Constituição Brasileira de 1988, ao reconhecer legalmente a união estável e outras formas de vida íntima, indica uma abertura do direito e da legislação à diversidade de costumes e às pluralidades.

Desse modo, o Estatuto da Criança e do Adolescente, de 1990, parece seguir a mesma tendência da Constituição Federal e, embora mencione repetidas vezes o termo "família", não o regulamenta ou define um modelo prescrito, indiciando um reconhecimento da pluralidade que esse termo assume na contemporaneidade. No entanto, esse reconhecimento de diferentes formas de organização familiar como legalmente possíveis não parece implicar somente um recuo do controle estatal na vida íntima. Como afirma Koerner, indica também um reinvestimento, isto é, uma outra maneira pela qual a família articula-se à ordem política e social. ${ }^{147}$

No que se refere à punição e ao tratamento dos adolescentes autores de ato infracional, essa articulação dá-se, por um lado, pela afirmação da importância da família tanto no nível geral, de instância que deve garantir os direitos do adolescente, quanto no nível específico, em que ela se torna parte do processo socioeducativo.

\footnotetext{
${ }^{146}$ A idéia de que a característica mais central da vida familiar na modernidade é a interferência do Estado parte das contribuições de Émile Durkheim (1975a).

${ }^{147}$ Koerner, 2002:82.
} 
No nível específico, a afirmação da importância da família implica também uma mudança de estratégia no tratamento do autor de ato infracional, que se desloca da substituição da vida familiar, como é o caso da estratégia de encarceramento, para a manutenção desse convívio. Esse descolamento levanta duas questões: primeiro, a entrada da família como parte do processo socioeducativo; segundo, essa entrada em uma posição estratégica hierarquicamente inferior, como alvo da intervenção do Estado e da sociedade.

Assim, a entrada da família no processo socioeducativo não parece indicar a retração do controle estatal na vida familiar. Pelo contrário, salienta a tendência de expansão desse controle, que se legitima pela re-educação da pessoa em desenvolvimento. No entanto, com a desinstitucionalização da família na contemporaneidade e o crescimento das incertezas e das possibilidades referentes a ela, esse controle parece exercer-se, cada vez mais, sob a forma de gestão das incertezas em vez de manifestar-se como tentativa de estabilização e padronização do permitido e do proibido. ${ }^{148}$

Desse modo, o desenvolvimento das técnicas psicológicas, eficientes no controle das famílias contemporâneas, por darem conta de abarcar sua diversidade de composições, pode ser entendido não como substituto ou concorrente da intervenção estatal, mas como uma forma de operacionalizá-la.

Por conseguinte, se a existência de um modelo familiar único está em declínio, diminuindo as possibilidades de um controle social do permitido e do proibido, isso não significa que a família tenha deixado de ser um ponto de investimento de poder, mas que este tende a operar cada vez mais por outros registros que não o da repressão. Nesse sentido, a questão teórica que se coloca é abordar a flexibilização legislativa ou a diminuição do controle repressivo do Estado sobre as famílias não como uma retração, mas como uma difusão de mecanismos mais discretos e, no contexto atual, mais eficientes porque mais adaptáveis ao aumento do número de variações possíveis.

\footnotetext{
${ }^{148}$ Ver também Koerner, 2002.
} 


\section{A importância da norma na reflexão sobre família, indivíduo e Estado: a gestão}

\section{das incertezas.}

Trata-se, então, de abordar a família também como um ponto de investimento de poder que visa regulamentar a produção de individualidades. Assim, para além da polêmica sobre a família poder ser, na contemporaneidade, a instituição central nos processos de socialização e individualização de crianças e adolescentes, a questão é pensar como essa possibilidade faz dela objeto de diferentes exercícios de poder. Nesse sentido, as reflexões de Michel Foucault (1999a, 1999b, 2000) e Jacques Donzelot (1986) tornam-se fundamentais.

Analisando a sociedade francesa, Michel Foucault (1999b; 2000) aponta que a passagem do século XVIII para o século XIX foi marcada por um deslocamento nas formas de exercício de poder, de cima para baixo e do centro para as franjas. Esse deslocamento transformou profundamente os princípios estratégicos de Estado, de tal modo que a soberania, o campo jurídico da lei e o direito assimétrico do soberano de dispor da vida de seus súditos teriam perdido sua centralidade, tornando-se peças complementares no exercício de um novo poder. Tratava-se da emergência do poder sobre a vida, cuja legitimidade não seria garantida pelo direito do soberano de determinar a morte, mas pelo direito do corpo social de manter sua vida e desenvolvê-la. Assim, seus objetivos não visariam à repressão ou a destruição, mas à maximização da vida como princípio central das estratégias de Estado, tanto em seu investimento no nível individual quanto no populacional. Nesse sentido, seria um poder que se exerce, positivamente, sobre a vida, que empreende sua gestão, sua majoração, sua multiplicação, buscando a criação, a produção e o acréscimo de forças por meio da articulação de técnicas de ordenação das individualidades e de regulamentação dos fenômenos populacionais. ${ }^{149}$

O desenvolvimento dessas técnicas dar-se-ia em duas etapas. Em primeiro lugar, a partir do século XVII, teria havido um investimento de poder sobre o

\footnotetext{
${ }^{149}$ Foucault, 1999b:129.
} 
corpo individual, visando seu adestramento, a maximização de sua força econômica e a diminuição de sua resistência política, isto é, uma anátomo-política do corpo humano. $^{150}$ Essa descoberta do corpo como alvo e objeto de poder teria sido acompanhada pelo desenvolvimento de técnicas que viabilizavam o controle detalhado das operações do corpo individual e, assim, tornavam possível o exercício de um poder disciplinar. ${ }^{151}$

Ao incidir sobre os corpos individuais, a disciplina produziria uma individualização pelo poder que inverte o eixo individualizador, do homem memorável para o homem calculável, do mestre para os discípulos, do soberano para os súditos, enfim, das regiões superiores do poder para as inferiores. Nesse sentido, o desenvolvimento das técnicas disciplinares nos séculos XVII e XVIII significaria uma primeira ruptura no campo do direito do soberano. Embora essa ruptura ainda não tenha sido a configuração de um poder sobre a vida, pois o problema da vida ainda não constituía um fenômeno a ser gerido pelo Estado, a disciplina permitiu um deslocamento da ruidosa ostentação de força do soberano para o escrutínio discreto das extremidades capilares dos súditos, uma vez que ela descentraliza e dissemina um instrumento de controle sobre os indivíduos que vai muito além do alcance das leis e suas prescrições fixas. Com a disciplina, ter-se-ia a ascensão da norma, que não se estabelece a partir de preceitos gerais de certo e errado, mas pela observação, avaliação e valoração das condutas individuais consideradas em seu conjunto.

Em todo sistema disciplinar, haveria o funcionamento de um microsistema penal, que visa punir a inobservância das regras e a inadequação à regularidade entre os indivíduos. Dito de outro modo, a punição disciplinar opera como uma sanção normalizadora que tem como objetivo reduzir os desvios individuais em relação a um quadro médio e gradativo de condutas, desempenhos e aptidões considerados regulares e normais. Buscando diminuir os desvios em relação à média dos indivíduos, essa sanção é essencialmente corretiva e privilegia

\footnotetext{
${ }^{150}$ Foucault, 1999b:131; grifo original.

151 Sobre o adestramento e a obtenção da docilidade do corpo, ver, principalmente, Foucault, 1999a:117-42.
} 
o exercício e o caráter pedagógico da punição. Assim, coloca-se menos como uma vingança coletiva contra uma lei ultrajada ou contra um indivíduo que, infringindo a lei, fere o sentimento coletivo que ela representa, e mais como um processo racionalizado de treinamento e correção dos comportamentos pela repetição exaustiva de exercícios específicos. ${ }^{152}$

Por conseguinte, essa sanção põe em funcionamento a normalização, isto é, cria normas, ao mesmo tempo que produz indivíduos conformados a elas por intermédio de cinco operações. Em primeiro lugar, exige um registro das condutas e dos desempenhos no conjunto de indivíduos que se pretende normalizar, o que permite a comparação entre eles e o estabelecimento de um padrão ou uma regra a ser seguida pelo conjunto. Em segundo, diferencia cada indivíduo tanto em relação aos demais, quanto em relação a essa regra de conjunto. Então, hierarquiza-os por meio da qualificação de suas condutas e desempenhos a partir dos valores opostos de bem e mal - isto é, a boa e a má conduta, o bom e o mau desempenho - e sua quantificação em escalas gradativas. Enfim, a normalização estabelece o limite para a diferença individual, para o desvio que está além da escala de normalidade, e o exclui, criando uma barreira externa contra a anormalidade.

Exercendo-se sobre os indivíduos, a norma disciplinar significaria um investimento de poder que produz individualidades normais e anormais, tipos humanos normais e desviantes. Tendo indivíduos e não grupos como alvo de aplicação, ela pouco contribuiria, aparentemente, para uma revisão da abordagem tradicional da família moderna como uma instituição socializadora, cuja noção de regras prescritas a aproximava do campo soberano da lei. No entanto, uma vez que a concepção moderna de indivíduo atém-se ao modelo de construção continuada pelas instituições, é possível pensar se e em que medida a família moderna teria se convertido em uma instituição disciplinar, passando a operar em um registro de produção das novas gerações pela norma e não somente pela lei. Nesse sentido,

\footnotetext{
${ }^{152}$ Entre os instrumentos disciplinares apontados por Michel Foucault (1999a:143-61), há a vigilância hierarquizada, a sanção normalizadora e o exame. Desses, a sanção normalizadora merece maior destaque por caracterizar a normalização. A vigilância hierárquica, por sua vez, constitui aparelhos de observação, registro e treinamento que atuam constantemente em instituições disciplinares. Já o exame permite o registro documentário e a transformação de cada indivíduo em um caso, sendo uma inversão da visibilidade pelo poder e um mecanismo de objetificação.
} 
Foucault aponta para a necessidade de analisar o modo como as relações familiares, principalmente, entre pais e filhos, se "disciplinaram", absorvendo desde a era clássica esquemas externos, escolares, militares, depois médicos, psiquiátricos, psicológicos, que fizeram da família o local de surgimento privilegiado para a questão disciplinar do normal e do anormal. ${ }^{153}$

Operando em diferentes instituições sociais, a disciplina permitiria uma primeira abordagem da família, no sentido de uma inversão dos eixos de poder do pai, patriarca soberano, para a criança, ou seja, o poder da família moderna se exerceria menos em nome do pai e mais em nome da criança, visando sua transformação no indivíduo adulto normal e saudável. Assim, a vida familiar teria se reorganizado internamente de modo a assegurar a saúde e a educação das novas gerações. Nesse sentido, houve mudanças no espaço do lar que se aproximaram de um esquadrinhamento disciplinar, tais como a separação entre o quarto do casal e o quarto do filho, que procuraram dar à casa uma certa funcionalidade e organização, separando os ambientes de acordo com critérios de salubridade e intimidade. Houve também uma divisão do tempo familiar, tanto de acordo com uma lógica interna de rotinização e repetição de seqüências, como tempo de estudar, de trabalhar, de comer, de dormir e de lazer, quanto de acordo com uma linearidade das idades progressivas da família, desde a constituição do casal, passando pelas etapas de nascimento e criação dos filhos, pelo momento em que os filhos deixam o núcleo de origem, até a velhice do casal.

No entanto, faltava a essa instituição um certo grau de "auto-gestão", uma intencionalidade interna que desse sentido a sua conversão disciplinar. ${ }^{154}$ Para o exército, esses mecanismos formavam o soldado eficiente, para a escola, o aluno exemplar, para a fábrica, o operário ideal, para a prisão, o preso subserviente. Por suas técnicas, a disciplina permitia a essas instituições produzirem tipos específicos ou espécies de indivíduos cujas características gerais seriam a docilidade política e a força econômica. E para a família? Seria a criança saudável e normal? Ou não seria esse um objetivo mais geral? Efetivamente, uma dificuldade que se coloca na

\footnotetext{
153 Foucault, 1999a:177-8.

154 Para uma abordagem dos limites da autonomia familiar moderna, ver Lasch, 1991.
} 
abordagem da família enquanto instituição disciplinar é essa ausência de clareza quanto a uma intencionalidade própria para a adoção das técnicas disciplinares. Essa adoção parece visar menos a produção de uma individualidade específica - o soldado, o aluno, o operário ou o delinqüente - e mais a construção de uma historicidade ou biografia que servirá para dar sentido a essa individualidade.

Se, por um lado, não é muito clara a intenção da família em se disciplinar, a não ser para ter como efeito genérico a produção do indivíduo normal e saudável, a intenção de outras instituições de discipliná-la em nome dessa produção é, por outro lado, explícita. No que se refere à infância, haveria, pelo menos, duas linhas de controle externo sobre a família. A primeira delas situar-se-ia no registro da lei e asseguraria ao Estado uma interferência permanente na vida familiar como forma de, independentemente da vontade paterna, regulamentar os laços entre pais e filhos. ${ }^{155}$ Uma vez configurada essa interferência, uma segunda linha de controle busca normalizá-los, criando padrões médios de conduta e desempenho familiar que permitiriam traçar uma escala gradativa de pequenos desvios toleráveis e uma linha divisória com o extremamente outro: a família anormal.

Na segunda linha de controle, a escola talvez seja o exemplo mais evidente de controle normalizador sobre a família. O alvo privilegiado de investimento do poder escolar seria, sem dúvida, a criança, o aluno a ser educado. No entanto, seus mecanismos tenderam à ramificação e à extensão, passando a incidir sobre a vida familiar dos alunos fora da instituição. Além da escola, o desenvolvimento da medicina doméstica entre os séculos XVIII e XIX e o problema da saúde e da produção do indivíduo saudável implicaram a intensificação do controle externo sobre a família, considerada como foco da saúde e da doença das novas gerações.

Essa linha de controle das relações familiares inter-geracionais, uma espécie de normalização exercida por outras instituições e mecanismos,

\footnotetext{
${ }^{155}$ Segundo Durkheim (1975b), a característica mais distintiva da família moderna é a interferência do Estado na vida familiar, de modo que a paternidade passa a ser assegurada pela legislação e não depende mais da vontade do patriarca (que poderia negar ou romper a paternidade, como no caso da deserção). Assim, há uma considerável redução do pátrio poder, que passa a ser gerido pelo Estado.
} 
transformaria a família na "célula-máter" da sociedade, menos como instituição fechada de reprodução social e mais enquanto lugar de incidência e experimentação de técnicas reprodutivas. Historicamente, tais técnicas teriam se desenvolvido com a medicina doméstica, cujo problema era a produção do corpo saudável no espaço familiar, passando para a medicina higiênica e a questão da saúde pública, que se direcionava para uma higienização das famílias como forma de maximização da vida da população.

Para Foucault (1999b, 2000), essa problematização da vida teria emergido a partir da articulação entre disciplina do corpo e regulamentação da população. Assim, enquanto a disciplina produziria indivíduos, a regulamentação os massificaria em processos de conjunto. Uma e de outra seriam duas etapas e duas formas não-excludentes, mas complementares, do biopoder, que se exerceria por meio da circulação da norma entre técnicas pedagógicas, médicas e demográficas. Dessas, a medicina torna-se central porque permite a circulação da norma disciplinar e regulamentadora, enquanto a pedagogia focaliza a disciplina do corpo individual e a demografia, a regulamentação dos fenômenos de população.

Um exemplo da centralidade da medicina na articulação entre corpo e espécie seria o surgimento da teoria da degenerescência hereditária, na segunda metade do século XIX. De acordo com ela, as condutas individuais tidas como indesejadas, desvalorizadas ou mesmo perigosas seriam características biológicas da raça humana, transmitidas como herança genética entre as gerações de degenerados. ${ }^{156}$ Nesse contexto de maximização da vida pela preservação da raça, expandiriam-se os inventários exaustivos e as classificações minuciosas dos indivíduos considerados anormais, agrupando-os em espécies desviantes - tais como loucos, débeis, indisciplinados, tuberculosos. ${ }^{157}$ Ademais, a aliança entre a categorização desses indivíduos e a noção de que suas características seriam

\footnotetext{
${ }^{156}$ Sobre o impacto da teoria da degenerescência hereditária e sua contrapartida nos defensores da ordem pelas vias da educação, ver Fernandes, 1994:109-46.

157 Em sua abordagem sobre a teoria da degenerescência no final do século XIX, Elizabeth Roudinesco assinala quem eram os desviantes: A mulher, o louco, o judeu, o criminoso e o tarado: estes eram os nomes comuns de uma ideologia da degenerescência em que circulava, através de todos os fanatismos, a visão de uma humanidade reduzida a suas categorias hereditaristas. (Roudinesco Apud Fernandes, 1994:112).
} 
transmitidas à prole legitimava sua exclusão do convívio social e seu confinamento em espaços fechados de segregação em nome da garantia de pureza da raça e da eliminação da possibilidade de contágio das gerações descendentes. ${ }^{158}$

Visando à prevenção de doenças e à conservação da saúde da geração futura, a teoria da degenerescência hereditária articulava as tecnologias biomédicas de controle do corpo individual e o problema da vida e da doença da população. Além disso, produzia uma noção de "responsabilidade biológica" com relação à espécie que incidia diretamente como controle sobre as famílias, seus critérios de formação e procriação.

Porém, a conversão das famílias em ponto de aplicação das técnicas médicas, disciplinares e regulamentadoras, não poderia negligenciar a clivagem social. Nesse sentido, Michel Foucault (1999b) aponta que as famílias das camadas mais favorecidas eram seu ponto de aplicação mais imediato e intenso, de modo a resguardarem o corpo saudável dos indivíduos de elite como forma de distinção social. Contudo, embora sua contribuição permita construir uma abordagem sociológica da família como ponto de investimento de poder, ela não aprofunda essa problematização a partir da clivagem social, no sentido de salientar as diferenças nos exercícios de tecnologias de poder que, tendo como alvo a infância e como objetivo a saúde e a educação das novas gerações, produzem efeitos políticos distintos.

Nesse sentido, a análise de Jacques Donzelot (1986) assinala que, contemporaneamente à ascensão do biopoder na França, a revalorização das tarefas educativas e as mudanças na imagem da infância levaram a uma reorganização das famílias em torno de duas estratégias pedagógicas diferentes. Tendo como base as contribuições de Michel Foucault, o autor procura apontar como as tecnologias biopolíticas que investem sobre o corpo e a espécie difundiramse de diferentes modos no tecido social. Assim, a família moderna, centrada na educação dos filhos, não pode ser pensada a partir da propagação de um mesmo

\footnotetext{
${ }^{158}$ A psiquiatria, mais a jurisprudência, a medicina legal, as instâncias do controle social, a vigilância das crianças perigosas, ou em perigo, funcionaram durante muito tempo 'pela degenerescência', pelo sistema hereditariedade-perversão. (Foucault, 1999b:112).
} 
modelo a todas as camadas sociais, cujas variações se dariam pela maior ou menor resistência ou adaptação a ele. Pelo contrário, haveria duas linhas estratégicas diferentes e (quase) concomitantes de promoção da preocupação educacional, com efeitos políticos diversos.

A primeira estratégia situar-se-ia no eixo de difusão da medicina doméstica, com suas normas disciplinares individualizantes que investiam sobre 0 corpo da criança de elite e que, em nome de sua saúde, transformaram a família em uma estufa aquecida contra as influências exteriores. ${ }^{159}$ Assim, a medicina doméstica teria como efeitos o fechamento da família em relação a influências exteriores prejudiciais (de nutrizes e empregados) e o estabelecimento de uma aliança com a mulher, que se tornaria responsável pelo bom andamento da educação dos filhos. Ademais, converteria a família em uma aliada contra as antigas estruturas de ensino religioso e do internato. Criaria, portanto, uma dupla frente de defesa da ação educativa saudável na esfera privada, com a mulher como representante; na esfera pública, com a atuação da família contra a educação nociva e a fundação de associações de pais e alunos. Enfim, o resultado desse eixo seria a reorganização das famílias em torno de um forte engajamento na educação dos filhos, que é, em contrapartida, pouco crítico e bastante dependente das normas e dos serviços médicos e, posteriormente, psicológicos.

No Brasil, o estudo de Jurandir Freire Costa (1999) segue a mesma linha de argumentação teórica e chega a proposições semelhantes com relação à difusão da medicina higiênica entre as famílias de elite no século XIX, como já foi tratado no capítulo anterior. Nesse sentido, a higienização engendraria a reorganização da vida familiar, ao promover mudanças na imagem da criança de elite por intermédio do tema da conservação da infância contra a degeneração e as influências nefastas. Entendida como uma das vertentes da modernização tardia, as técnicas médico-higienistas visavam romper os hábitos coloniais e adaptar as sociabilidades da elite aos padrões urbanos europeus da época, ou seja, objetivavam a europeização dos costumes, expulsando da intimidade familiar o

\footnotetext{
${ }^{159}$ Donzelot, 1986:24.
} 
convívio com os escravos e produzindo individualidades cujo cuidado com a saúde e com o corpo marcavam a afirmação de si e a distinção com relação às camadas populares.

Embora deixe claro que as técnicas médico-higienistas não incidiam sobre essas camadas, Costa (1999) não desenvolve essa diferenciação no contexto brasileiro. Donzelot (1986), por sua vez, salienta a existência de uma segunda estratégia de promoção da preocupação educacional na sociedade francesa, que teria como ponto de aplicação as famílias populares. Tratava-se da constituição de um eixo de economia social, em que o objetivo seria menos a individualização saudável da criança e mais a integração e conservação da população pela diminuição do custo social de sua reprodução. Suas técnicas visariam o controle das uniões livres entre homens e mulheres e a coibição do abandono de crianças e das linhas de fuga em relação à família.

Nesse sentido, no século XIX, desenvolver-se-iam técnicas filantrópicas que, num primeiro momento, tencionavam restaurar o casamento nas camadas operárias por meio das táticas de revalorização do trabalho doméstico feminino como substituição do dote e de aconselhamento para formação de poupança. ${ }^{160}$ Num segundo momento, surgiriam as técnicas filantrópico-higienistas, que difundiam as normas de higiene e bem-estar da população, por meio da escolarização e dos movimentos de sanitarização das habitações populares. Já no final do século XIX, seria firmada a colaboração entre justiça e filantropia, uma aliança entre as técnicas filantrópicas e as estratégias de Estado, que visava articular os temas da criança em perigo e da criança perigosa e que marcaria a emergência do complexo tutelar.

O complexo tutelar implicaria um duplo processo de tutelarização da autonomia familiar, quando as normas educacionais e de saúde não eram

\footnotetext{
${ }^{160}$ Na França da segunda metade do século XIX, a ação dos filantropos na formação de sociedades patronais passou a organizar a entrada das mulheres de classes populares no mercado de trabalho em torno da aquisição de uma competência doméstica. Assim, em suas carreiras femininas, o trabalho assalariado tornava-se uma necessidade ocasional e não um destino. No que se refere ao aconselhamento e incentivo à poupança, a filantropia tinha como efeito a despolitização da questão pública da distribuição de renda por meio de sua transformação em um problema privado de moralidade econômica familiar. Cf. Donzelot, 1986, 49-89.
} 
respeitadas e eram acompanhadas de pobreza, e de intensificação da normalização dessas famílias inicialmente refratárias, por intermédio da vigilância direta. Assim, reuniria duas formas de exercício de poder sobre as famílias pobres, quais sejam, a forma soberana de repressão jurídica pela imposição da tutela e a forma biopolítica de normalização como modo de operacionalização tutelar. ${ }^{161}$

Porém, suas normas seriam mais marcadamente assistenciais e estariam vinculadas ao surgimento das profissões de trabalho social no final do século XIX. Privilegiando o problema da convergência da infância em perigo e da infância perigosa, os assistentes sociais, educadores e orientadores passaram a produzir saberes criminológicos que traçavam um perfil padronizado do futuro delinqüente, biográfico e familiar. A partir desse perfil, procuravam instaurar uma infra-estrutura de prevenção que fazia da educação uma extensão vigilante do judiciário. Dessa feita, a criança popular desenvolver-se-ia em um modelo pedagógico de liberdade vigiada, que a direcionava para espaços de maior vigilância como a escola e a habitação familiar.

No Brasil, a promulgação do Código de Menores, em 1927, e a estatização da assistência social, ao longo do século $X X$, parecem indicar que a ascensão de um complexo tutelar seguiu por outros caminhos. Como discutido no capítulo anterior, o objetivo de contenção da desordem e de controle dos desvios individuais das camadas populares não significou, pelo menos em um primeiro momento, que a canalização das possíveis linhas de fuga levasse a um redirecionamento da criança para a família ou para a escola. ${ }^{162}$ Assim, a aliança entre assistência filantrópica e estratégias de Estado, no tratamento do problema da infância perigosa, engendrou políticas de substituição dos cuidados familiares pelos assistenciais estatais, aliadas a uma concepção de justiça recuperadora dos desvios individuais, pelo isolamento. Conseqüentemente, a internação como prática privilegiada para o controle dos desvios permitiu o desenvolvimento de técnicas de

\footnotetext{
${ }^{161}$ Vale ressaltar que essa dimensão biopolítica não pode ser entendida somente como um poder que se exerce sobre a vida e sobre a população, mas também como um poder que visa a maximização da vida das classes populares por meio da redução econômica dos custos de sua reprodução.

${ }^{162}$ As linhas de fuga são pensadas como formas de desvio ao modelo de socialização família-escolafábrica e referem-se a crianças e adolescentes que vivem pelas ruas e transitam entre atividades lícitas e ilícitas.
} 
individualização pelo poder em um duplo sentido, sendo o primeiro a atomização, isto é, a tendência de isolamento e ruptura em relação às sociabilidades familiares e comunitárias de sua vida pregressa, e o segundo, a produção de individualidades assujeitadas enquadradas na categoria menor. ${ }^{163}$

Nesse sentido, cabia pensar em uma normalização do desvio, isto é, em um investimento de poder que agrupou um conjunto de indivíduos, crianças e adolescentes que ameaçavam a ordem social, e estabeleceu regras de homogeneização desse conjunto pela pobreza, pela não adequação de suas famílias às normas educativas e médicas adotadas pelas famílias de elite e por sua tendência de fuga em direção à rua, à economia informal e à delinqüência. Tratavase, também, da constituição de um aparelho tutelar para gerir essa normalização, materializado pelo circuito das agências policiais, dos tribunais de justiça e das instituições de "bem-estar do menor" e operacionalizado pela constante e intensa produção de saberes sociais sobre os internados. Esses saberes, construídos pela documentação e registro dos casos individuais em prontuários, geraram uma ramificação e uma extensão do investimento de poder para as famílias, que só se cristalizaria no final do século XX. ${ }^{164}$

Por conseguinte, a promulgação do Estatuto da Criança e do Adolescente, em 1990, marca o estabelecimento de novos rumos na normalização do desvio. Ao definir a internação como excepcional e privilegiar as medidas socioeducativas em meio aberto, destacando-se a liberdade assistida, ele significa um deslocamento das relações de poder entre as famílias pobres de adolescentes autores de ato infracional e o Estado, no sentido de um re-direcionamento das

\footnotetext{
163 Essa é uma leitura da construção da identidade do menor pela perspectiva institucional da internação. Uma leitura pelo viés das biografias de indivíduos que passaram pela experiência precoce de punição e internação pode ser encontrada na contribuição de Sérgio Adorno (1991), que caracteriza essas biografias por processos de desterritorialização, isto é, um abandono progressivo dos espaços institucionais da ordem e um afastamento da constelação familiar e da escola, e uma reterritorialização pela construção de uma identidade delinqüente.

164 Segundo Gutemberg Rodrigues (2001:193), o item "família" dos prontuários dos adolescentes da Febem/SP apresenta a desagregação familiar como característica intrínseca das camadas pobres da sociedade, marcada pela ausência de preocupação com o destino dos filhos e pelo descuido com a higiene.
} 
políticas ressocializadoras de substituição dos cuidados familiares para as políticas de transferência, para as famílias, da responsabilidade pela ressocialização.

Esse deslocamento tem ao menos duas conseqüências. Primeiro, uma mudança no eixo de individualização desses adolescentes e nas possibilidades de construção de suas biografias, a partir de uma maior diversificação dos tipos de controle. Enquanto o controle institucional da internação tende a polarizar a relação indivíduo-Estado no binômio adolescente-monitor, a liberdade assistida diminui a tensão, inserindo novas relações de poder no jogo da ressocialização. Nesse sentido, trata-se da intensificação da normalização que amplia a escala de diferenciações entre os indivíduos e relega a internação para os casos "extremos", os desvios dos desvios, aqueles indivíduos que se revelaram refratários às técnicas de controle menos repressivas. Em segundo lugar, há uma mudança no lugar ocupado pela família, que não deixa de ser responsabilizada pelo desvio biográfico do passado e pela produção de uma individualidade "delinqüente", mas também passa a ser responsável pela correção desse desvio. Dessa forma, trata-se da instauração de um modelo pedagógico-familiar de liberdade assistida que, com suas tecnologias de ortopedia social, invade a vida íntima das camadas menos favorecidas.

A invasão da terapêutica em nome da correção de condutas indica novas formas de intervenção do Estado na vida íntima dos pobres e a ascensão de uma "pedagogia familiar compulsória". Assim, mecanismos de normalização familiar tendem a operar no eixo tutelar-assistencialista de produção de individualidades.

Porém, o sentido dessa normalização não parece ser a desestruturação familiar entendida somente como uma desinstitucionalização da família, ou seja, como a busca de adequação a regras ou o estabelecimento de um padrão familiar normal em nome da correção das condutas individuais. Dado o contexto contemporâneo de desinstitucionalização generalizada da família, a terapêutica socioeducativa tende a indicar também que a colonização da vida familiar visa produzir novas formas de gestão das incertezas nesse contexto, por 
intermédio da redução da autonomia das famílias e do acréscimo de sua tutelarização pelos serviços psicológicos e assistenciais.

Enfim, se, visando controlar os processos de socialização e individualização de crianças e adolescentes, a interferência do Estado e de outras instituições na vida familiar não constitui algo realmente novo, deve-se considerar as transformações históricas no modo pelo qual essa interferência ocorre. Nesse sentido, as propostas socioeducativas do Estatuto da Criança e do Adolescente permitem uma mudança estratégica do encarceramento do indivíduo e da repressão de sua vida familiar para outras formas de tutela, mais flexíveis e, também, mais eficazes, que tendem a colonizar seu mundo doméstico. Resta saber quais são os efeitos dessa nova estratégia tanto para os adolescentes assim socioeducados quanto para suas famílias, também socioeducadas. 


\section{CONCLUSÃO}

O Estatuto da Criança e do Adolescente parece apontar que, no contexto brasileiro, a proposta do Estado democrático envolve um projeto de políticas individualizantes que não excluem, mas priorizam, a ligação com a família. Assim, não se trata de uma interferência estatal na vida privada que vise libertar o indivíduo dos comunitarismos, deveres e obrigações característicos dos laços familiares; antes, essa interferência objetiva o restabelecimento desses laços e afirma o primado educacional como responsabilidade dos pais. É uma proposta de individualização que não pretende criar antagonismos, mas circularidades e até simbioses, entre família e indivíduo.

Por um lado, essa proposta parece evitar a ascensão de biografias de risco, uma vez que a priorização dos vínculos familiares de origem inibe a exigência de biografias autênticas e acentua as solidariedades grupais. Por outro, gera novas contradições, ou melhor, novas formas de construção de biografias de risco, pois os vínculos familiares contemporâneos não têm condições de oferecer à pessoa em desenvo/vimento a segurança e o amparo supostamente atribuídos a eles. Isso não implica despreparo ou "desestruturação" das famílias contemporâneas em relação ao modelo moderno, uma vez que nem mesmo este detinha o controle sobre os processos de socialização e formação das novas gerações. A modernidade caracteriza-se justamente pela complexificação da vida social, que retira das famílias a exclusividade dessa formação e, assim, torna possível a existência de diferenças individuais.

Ora, se os vínculos familiares não podem oferecer o controle necessário ao sucesso da socioeducação de adolescentes em conflito com a lei, o conceito de individualização em jogo nas diretrizes do Estatuto, que defendem a desinternação e o direcionamento para a família como lugar de correção das condutas desviantes, tende mais a ser uma problematização da produção de individualidades assujeitadas do que a do isolamento do indivíduo e sua 
transformação na unidade de reprodução da vida social. Nesse sentido, individualizar significa diluir os mecanismos de controle dos desvios que incidem diretamente sobre os adolescentes e ramificá-los em direção à sua vida íntima, cercando-os de uma vigilância constante e fazendo de sua liberação em relação aos controles repressivos da internação uma liberdade assistida por controles mais sutis e, por isso, mais eficientes.

A construção desse quadro de liberdade assistida implica a acentuação da tutelarização da autonomia familiar, em que as relações familiares são colonizadas por técnicas psicológico-assistenciais de gestão privatizada dos desvios individuais e operacionalizadas como ponto privilegiado de surgimento e administração do normal e do anormal. Assim, o Estatuto muda as relações de poder entre Estado e famílias pobres, no sentido de engendrar políticas de controle da vida familiar, que transferem para estas a responsabilidade pelos adolescentes ao mesmo tempo que criam instrumentos de regulamentação que as atingem e controlam. No limite, trata-se de um investimento na normalização da vida familiar que visa reduzir os custos da reprodução social e assegurar uma maior eficiência no controle dos desvios. Ao inserir a família no processo socioeducativo dos adolescentes autores de ato infracional, o Estatuto da Criança e do Adolescente implica, aparentemente, uma incongruência histórica, a saber, a de re-afirmar a importância da família em um contexto em que, cada vez mais, ela perde a possibilidade de exercer algum tipo de controle sobre a construção de individualidades e de identidades sociais e pessoais. 


\section{BIBLIOGRAFIA DE REFERÊNCIA}

ADORNO, Sérgio, LIMA, Renato Sérgio de \& BORDINI, Eliana B. T. O adolescente na criminalidade urbana de São Paulo. Brasília: Ministério da Justiça, Secretaria de Estado dos Direitos Humanos, 1999. 76 p.

ADORNO, Sérgio. A experiência precoce da punição. In. MARTINS, José de Souza (coord.). O massacre dos inocentes: a criança sem infância no Brasil. São Paulo: Hucitec, 1991. p. 181-208.

ALVAREZ, Marcos César. A emergência do Código de Menores de 1927: uma análise do discurso jurídico e institucional da assistência e proteção aos menores. Dissertação (Mestrado). São Paulo: Departamento de Sociologia FFLCH/USP, 1989. 235 p. Mimeo.

ALVIN, M. Rosilene Barbosa \& VALLADARES, Licia do Prado. Infância e sociedade no Brasil: uma análise da literatura. Boletim Informativo e Bibliográfico de Ciências Sociais (BIB). Rio de Janeiro: n. 26, 1988. p. 03-37.

ANISTIA INTERNACIONAL. Brasil: desperdício de vidas. [São Paulo]: Anistia Internacional, jul. 2000. $31 \mathrm{p}$.

ARIĖS, Philippe. História social da criança e da família. Rio de Janeiro: Livros Técnicos e Científicos Editora S.A., 1981. 279 p.

AUGUSTO, Maria Helena Oliva. Tempo, indivíduo e vida social. Ciência e cultura. Revista da SBPC, ano 54, n.2, out./nov./dez, 2002. Núcleo temático sobre o tempo. p. 30-3.

. O moderno e o contemporâneo: reflexões sobre os conceitos de indivíduo, tempo e morte. Tempo social. São Paulo: vol. 6, n. 1-2, jun. 1995. p. 91-105.

ASSIS, Joaquim Maria Machado de. Esaú e Jacó. São Paulo: Ática, 1996. 192 p.

BACELLAR, Carlos de Almeida Prado. Abandonados nas soleiras das portas: a exposição de crianças nos domicílios de Sorocaba, séculos XVIII e XIX. In. FUKUI, Lia. (org.) Segredos de Família. São Paulo: Annablume: Nemge/USP: Fapesp, 2002. p. 15-41.

BATISTA, Vera Malaguti. Difíceis ganhos fáceis: drogas e juventude pobre no Rio de Janeiro. Rio de Janeiro: Editora Revan, 2003. 150 p.

BAUMAN, Zygmunt. Foreword by Zygmunt Bauman: Individually, together. In. BECK, Ulrich \& BECK-GERNSHEIM, Elisabeth. Individualization. Londres: Sage Publications, 2002. p. xiv-xix.

BECK, Ulrich. Risk society: towards a new modernity. Londres: Sage Publications, 1992. p. 91-150. 
BECK, Ulrich \& BECK-GERNSHEIM, Elisabeth. Individualization. Londres: Sage Publications, 2002. 221p.

BERGER, Peter \& BERGER, Brigitte. Socialização: como ser um membro da sociedade. In. FORACCHI, Marialice Mencarini. MARTINS, José de Souza. Sociologia e sociedade. Rio de Janeiro: Livros Técnicos e Científicos Editora, 1977. p. 200-14.

BERGER, Peter \& LUCKMANN, Thomas. A construção social da realidade. Petrópolis: Vozes, 1999. 247 p.

BIERRENBACH, Maria Ignês. Instituição fechada e violência: uma visão de dentro. In. BIERRENBACH, Maria Ignês, SADER, Emir. FIGUEIREDO \& Cyntia Petrocínio. Fogo no pavilhão: uma proposta de liberdade para o menor. São Paulo: Brasiliense, 1987. p. 37-128.

BRASIL. Câmara dos Deputados. Relatório IV Caravana Nacional de Direitos Humanos. Brasília: Câmara dos Deputados, 2000. 58 p.

BRASIL. Código penal. São Paulo: Saraiva, 1990. 480 p.

BRASIL. Constituição: República Federativa do Brasil. Brasília: Senado Federal, Centro Gráfico, 1988. 193 p.

Brasil criança urgente: a lei. São Paulo: Columbus, 1990.195 p.

BRASIL. Estatuto da criança e do adolescente. São Paulo: Atlas, 1992. 189 p.

BRASIL. Ministério da Justiça. Atendimento ao adolescente em conflito com a lei: reflexões para uma prática qualificada. Brasília: Ministério da Justiça, Departamento da Criança e do Adolescente, 1998. 72 p.

CASTELLS, Manuel. O fim do patriarcalismo: movimentos sociais, família e sexualidade na era da informação. In. Paulo: Paz e Terra, 1999. p. 169-285. O poder da identidade. São

CELLARD, André. L'analyse documentaire. In. POUPART, Jean (et al.). La recherche qualitative. Montreal: Gaëtan Morin Éditeur, 1997. p.251-71.

CORREAA, Mariza. Repensando a família patriarcal brasileira. Cadernos de Pesquisal Fundação Carlos Chagas. São Paulo: n. 37, maio 1981. p. 05-16.

COSTA, Jurandir Freire. Ordem médica e norma familiar. Rio de Janeiro: Graal, 1999. 282 p.

CRUZ, Helena Maffei. Segredos, silenciamentos e apagamentos: família - mitos e conceitos. In. FUKUI, Lia. (org.) Segredos de Família. São Paulo: Annablume: Nemge/USP: Fapesp, 2002. p. 119-32.

DÉCHAUX, Jean-Hugues. Orientations théoriques en sociologie de la famille: autour de cinq ouvrages récents. Revue Française de Sociologie. Paris: $n$. XXXVI-3, jul./set. 1995. p. 525-50.

DONZELOT, Jacques. A polícia das famílias. Rio de Janeiro: Graal, 1986. 209 p. 
DOUGLAS, Mary. How institutions think. Syracure (NY): Syracure University Press, 1986. $146 \mathrm{p}$.

DUBAR, Claude. Pour une théorie sociologique de l'identité. In. . La socialization: construction des identités sociales et professionnelles. Paris: Armand Colin, 2002. p.107-23.

. Construction et crises de l'identité personnelle. In. . La crise des identités: l'interprétation d'une mutation. Paris: Presses Universitaires de France, 2001. p.163-218.

DURKHEIM, Émile. Educação e sociologia. São Paulo: Ed. Melhoramentos, 1978. 91 p.

. Introduction à la sociologie de la famille. In. sociales et institutions. Paris: Éditions de Minuit, 1975a. p. 09-34.

. La famille conjugale. In. Paris: Éditions de Minuit, 1975b. p. 35-49. Textes. 3. Fonctions sociales et institutions. . La educación moral. Buenos Aires: Editorial Losada S. A., 1947. 264 p.

FERNANDES, Florestan. A revolução burguesa no Brasil. Rio de Janeiro: Zahar, 1975. p. 15-30.

FERNANDES, Heloísa Rodrigues. Sintoma social dominante e moralização infantil: um estudo sobre a educação moral em Émile Durkheim. São Paulo: Edusp: Escuta, 1994. 213 p.

FIGUEIREDO, Cyntia Petrocínio. A questão do menor: uma proposta democrática. In. BIERRENBACH, Maria Ignês, SADER, Emir e FIGUEIREDO \& Cyntia Petrocínio. Fogo no pavilhão: uma proposta de liberdade para o menor. São Paulo: Brasiliense, 1987. p. 129-96.

FUNDAÇÃO ESTADUAL DO BEM-ESTAR DO MENOR \& FACULDADE DE SAÚDE PÚBLICA. Caracterização das famílias de jovens privados de liberdade da FEBEM/SP. Relatório Final de Pesquisa. São Paulo: Fundação Estadual do Bem-Estar do Menor: Faculdade de Saúde Pública - USP, 1998. 136 p. Mimeo.

FOUCAULT, Michel. Em defesa da sociedade. São Paulo: Martins Fontes, 2000. 382 p.

. Vigiar e punir. Petrópolis: Vozes, 1999a. 262 p.

História da sexualidade. Vol. I. Rio de Janeiro: Graal, 1999b. 152 p.

FREYRE, Gilberto. Casa grande \& senzala. Rio de Janeiro: Record, 1996. 569 p.

GOFFMAN, Erving. As características das instituições totais. In. Manicômios, prisões e conventos. São Paulo: Perspectiva, 1999a. p. $\overline{13-108 .}$ A representação do eu na vida cotidiana. Petrópolis: Vozes, 1999b. 233 p.

. Estigma: notas sobre a manipulação da identidade deteriorada. Rio de Janeiro: Editora Guanabara, 1988. 158 p. 
GREGORI, Maria Filomena. 4. A trama institucional. In. Viração: experiências de meninos nas ruas. São Paulo: Companhia das Letras, 2000. p. 159-213.

KOERNER, Andrei. Posições doutrinárias sobre o direito de família no pós-1988. Uma análise política. In. FUKUI, Lia. (org.) Segredos de Família. São Paulo: Annablume: Nemge/USP: Fapesp, 2002. p. 71-105.

KOSMINSKY, Ethel. Internados - os filhos do Estado padrasto. In. MARTINS, José de Souza (coord.). O massacre dos inocentes: a criança sem infância no Brasil. São Paulo: Hucitec, 1991. p. 155-80.

LASCH, Christopher. Refúgio num mundo sem coração. A família: santuário ou instituição sitiada? São Paulo: Paz e Terra, 1991. 252 p.

MARIN, Isabel da Silva Kahn. Febem, família e identidade: o lugar do Outro. São Paulo: Escuta, 1999. 123 p.

MARINS, Paulo César Garcez. Mulheres de elite, filhos naturais - São Paulo, séculos XVIII e XIX. In. FUKUI, Lia. (org.) Segredos de Família. São Paulo: Annablume: Nemge/USP: Fapesp, 2002. p. 43-60.

MEYER, Philippe. La correction paternelle ou l'État, domicile de la famille. Critique. Paris: tomo XXXI - n.343, dez. 1975. p. 1266-76.

MIRAGLIA, Paula. Rituais da violência: a Febem como espaço do medo em São Paulo. Dissertação (Mestrado). São Paulo: Departamento de Antropologia/ Universidade de São Paulo, 2001. 148 p. Mimeo.

MOURA, Esmeralda Blanco Bolsonaro de. Crianças operárias na recém industrializada São Paulo. In. DEL PRIORE, Mary (org.). História das crianças no Brasil. São Paulo: Contexto, 1999. p. 259-88.

OLIVEIRA, Régia Cristina. Jovens trabalhadores: representações sobre o trabalho na contemporaneidade. Dissertação (Mestrado). São Paulo: Departamento de Sociologia/ Universidade de São Paulo, 2001. 163 p. Mimeo.

OLIVEIRA, Salete Magda de. A moral reformadora e a prisão de mentalidades: adolescentes sob o discurso penalizador. São Paulo em perspectiva. São Paulo: n. 13(4), 1999. p. 75-81.

PARSONS, Talcott et alii. Family, socialization and interaction process. Glencoe: The Free Press, 1960. p. 03-131.

PARSONS, Talcott. Sociedades - perspectivas evolutivas e comparativas. São Paulo: Pioneira, 1969. p. 11-51.

PASSETTI, Edson. (coord.) Violentados: crianças, adolescentes e justiça. São Paulo: Ed. Imaginário, 1999a. 170 p.

PASSETTI, Edson. Crianças carentes e políticas públicas. In. DEL PRIORE, Mary (org.). História das crianças no Brasil. São Paulo: Contexto, 1999b. p. 347-75.

PAULA. Liana de. CAJE: instituição de recuperação ou escola de criminalidade? Relatório final apresentado ao Programa Institucional de Bolsas de Iniciação 
Científica - PIBIC. Brasília: Departamento de Sociologia/ Universidade de Brasília, jul. 2000a. 140 p. Mimeo.

- Re-socialização e sexualidade: estudo sobre as representações sociais da sexualidade de adolescentes infratores em uma instituição de contenção. Monografia (Bacharelado). Brasília: Departamento de Sociologia/ Universidade de Brasília, 2000b. 118 p. Mimeo.

PENTEADO, Jacob. O Belenzinho de outrora. In. Belènzinho, 1910: retrato de uma época. São Paulo: Carrenho Editorial: Narrativa Um, 2003. p. 57-66.

PIETROCOLLA, Luci Gati, SINHORETTO, Jacqueline \& CASTRO, Rosa. O judiciário e a comunidade: prós e contras das medidas sócio-educativas em meio aberto. São Paulo: IBCCRIM, 2000. 62 p.

RIBEIRO, Rosa Maria et alii. Estrutura familiar, trabalho e renda. In. KALOUSTIAN, Sílvio Manoug (org.). Família brasileira: a base de tudo. São Paulo: Cortez; Brasília: UNICEF, 1998. p.135-58.

RODRIGUES, Gutemberg Alexandrino. Os filhos do mundo: a face oculta da menoridade (1964 - 1979). São Paulo: IBCCRIM, 2001. 335 p.

SADER, Emir. Democracia é coisa de gente grande? In. BIERRENBACH, Maria Ignês, SADER, Emir \& FIGUEIREDO, Cyntia Petrocínio. Fogo no pavilhão: uma proposta de liberdade para o menor. São Paulo: Brasiliense, 1987. p. 09-36.

SALES, Mione. Relatório para exame de qualificação. Doutorado. São Paulo: Departamento de Sociologia/ Universidade de São Paulo, maio 2003. Mimeo. $55 \mathrm{p}$.

SALLA, Fernando Afonso. O trabalho penal: uma revisão histórica e as perspectivas frente à privatização das prisões. Dissertação (Mestrado). São Paulo: Departamento de Sociologia/ Universidade de São Paulo, 1991. 176 p. Mimeo.

SANTOS, Marco Antonio Cabral dos. Criança e criminalidade no início do século. In. DEL PRIORE, Mary (org.). História das crianças no Brasil. São Paulo: Contexto, 1999. p. 210-30.

SÃO PAULO (Estado). Liberdade assistida e prestação de serviços à comunidade: medidas de inclusão social voltadas a adolescentes autores de ato infracional. São Paulo: Instituto de Estudos Especiais da PUC/SP, Febem/SP, 1999. $69 \mathrm{p}$.

SARTI, Cynthia Andersen. A família como espelho: um estudo sobre a moral dos pobres na periferia de São Paulo. Tese (Doutorado). São Paulo: Departamento de Antropologia/ Universidade de São Paulo, 1994. 215 p. Mimeo.

SILVA, Roberto da. Os filhos do governo. São Paulo: Ática, 1997. 205 p. 
SINGLY, François de. Présentation - 2. La place centrale de la famille dans la construction de l'identité individualisée. In. Le soi, le couple, la famille. [Paris]: Nathan, [1996]a. p. 11-7.

. Conclusion - Les ailes et les racines. In. Le soi, le couple, la famille. [Paris]: Nathan, [1996]b. p. 211-33.

Sociologie de la famille contemporaine. Paris: Nathan, [1993]. 128 p.

SOUZA, Antonio Candido de Mello e. The Brazilian family. In. SMITH, L. \& MARCHANT, Al. (ed.). Brazil: portrait of half a continent. Nova lorque: Dryden, 1951. p. 291-312.

UNICEF et alii. Sugestões à municipalização em meio aberto. São Paulo: s/d. Mimeo. 18 p.

VAISTMAN, Jeni. Indivíduo, casamento e família em circunstâncias pós-modernas. Dados. Rio de Janeiro: vol. 38, n. 2, 1995. p. 329-53.

ZALUAR, Alba. A máquina e a revolta. As organizações populares e o significado da pobreza. São Paulo: Brasiliense, 1994. 265 p.

\section{Referências de jornais}

Folha de S. Paulo. "Projeto endurece regime para $2 / 3$ da Febem". Caderno Cotidiano, p. C1, em 23 de novembro de 2003.

. "Crime reabre debate sobre maioridade penal". Caderno Cotidiano, p. C1, em 15 de novembro de 2003.

\section{Referências de sítios}

Fundação Estadual do Bem-Estar do Menor - Febem. Dados sobre unidades de internação e semiliberdade do município de São Paulo. www.febem.sp.gov.br, em 26 de julho de 2004.

Folha de S. Paulo. Folha on-line. "Alckmin propõe pena de até 10 anos para adolescente". www.folha.uol.com.br, 19 de novembro de 2003.

Instituto Brasileiro de Geografia e Estatística - IBGE. Características dos domicílios chefiados por mulheres - Censo 2000. www.ibge.com.br, em 25 de agosto de 2004.

O Estado de S. Paulo. Agência Estado. "Alckmin leva à Câmara proposta de mudanças no Estatuto". www.estadao.com.br, em 19 de novembro de 2003.

São Paulo. Imprensa Oficial. Decreto n. 47.129, 24 de setembro de 2002. www.imprensaoficial.com.br, em 02 de março de 2003.

São Paulo. Imprensa Oficial. Decreto n. 8.777, 13 de outubro de 1976. www.imprensaoficial.com.br, em 10 de fevereiro de 2003. 